\title{
التوجهات الأيديولوجية لمواقع الصحف اليومية المصرية \\ وعلاقاتها بتحرير وتصميم صفحاتها الرئيسية \\ دراسة تحليلية
}

\author{
الباحث \\ ماجد ابراهيم حسن المنزلاوى الاتصى \\ دكتور اه الصحافة وتكنولوجيا الاتصال
}

P.r. 


\section{ملخص البحث}

مدخل الدراسة :

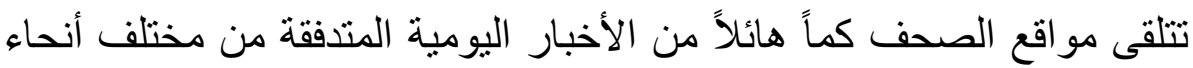

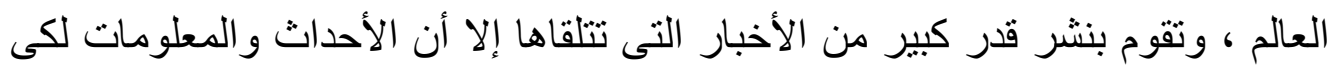

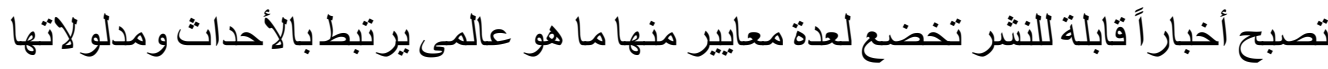

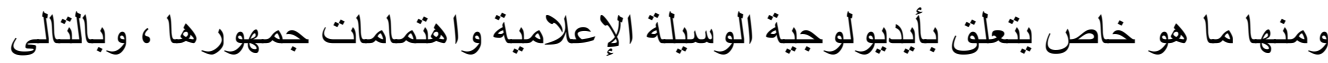

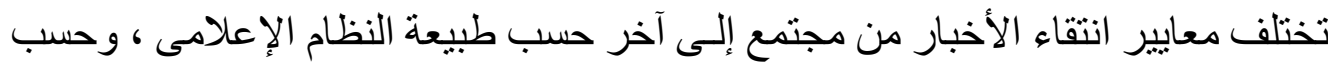

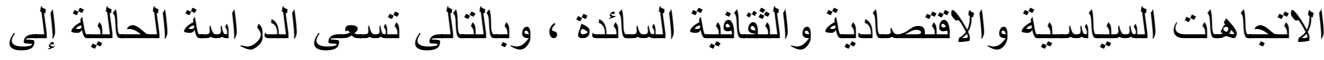

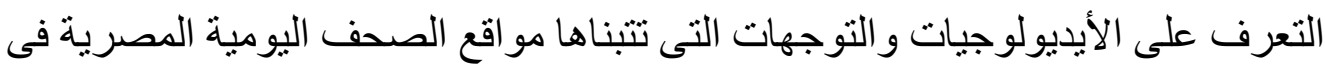

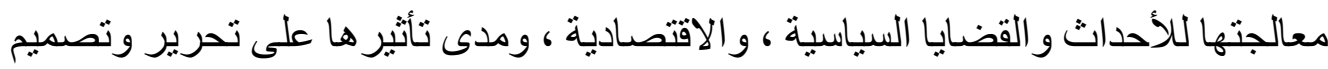

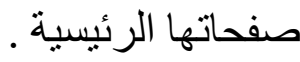

الإطار المنهجيق

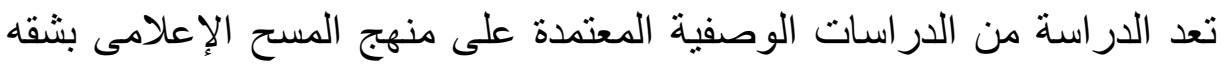
التحليلي التقييمي للمو اقع المصرية ، بالإضافة إلى أسلوب المقارنة المنهجية لمقارنة كل الصل

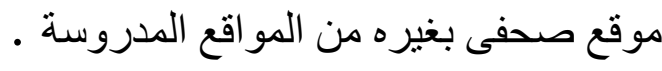

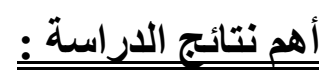

اــ أظهرت النتائج ضعف التغطية ذات الاتجاه المحايد فى المو اقع المصرية عينة

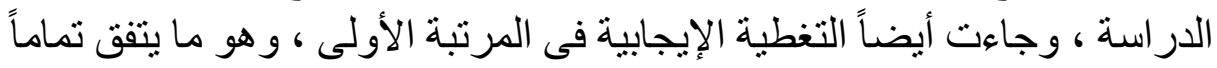

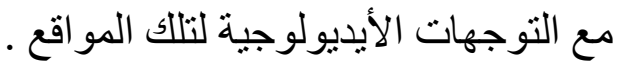

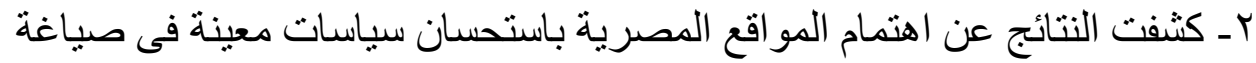

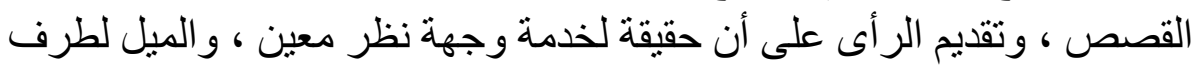

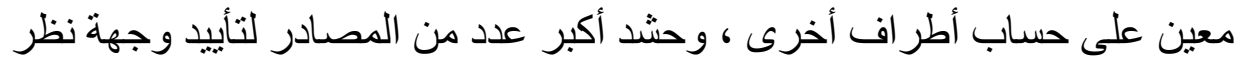

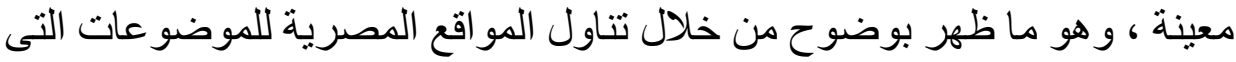

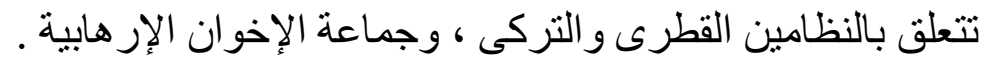

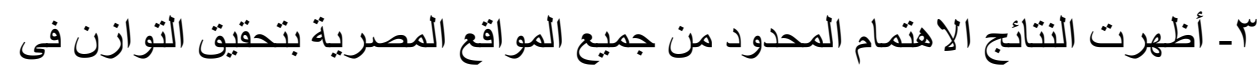

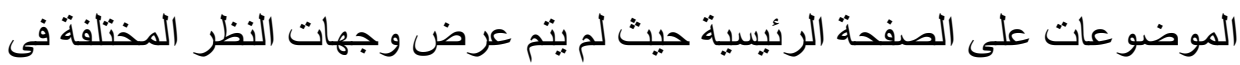
غالبية الموضو عات .

الكلمات الادالة:

(الأيديولوجية ، مواقع الصحف ، التحرير الإلكترونى ، تصميم المواقع ، الصفحة 
يعد الاهتمام بأيديولوجيا الرسالة الإعلامية وما تحمله من عقائد و أفكار فى صدارة

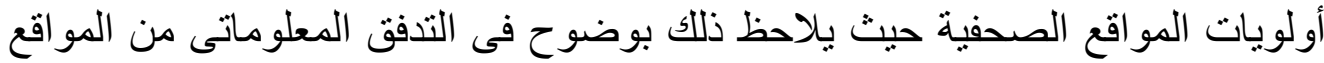

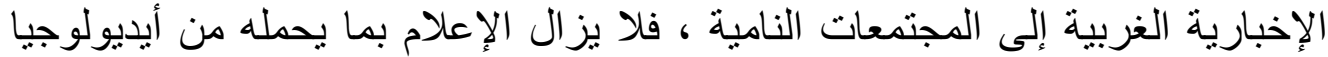

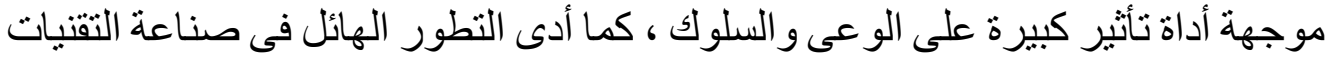

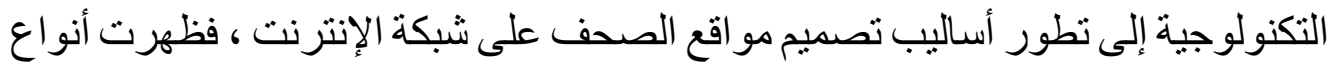

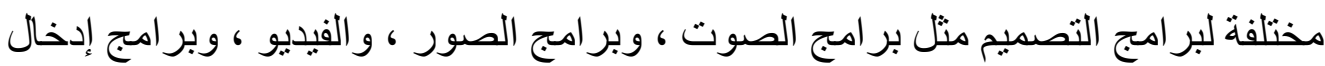

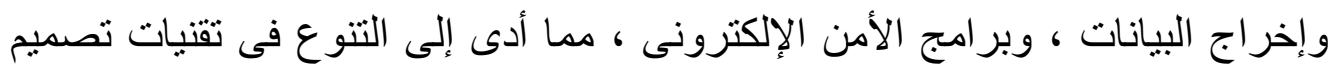

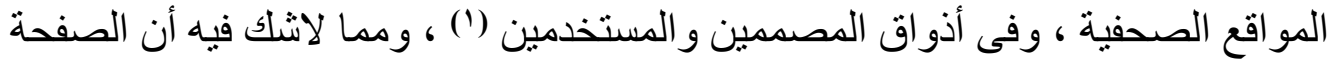

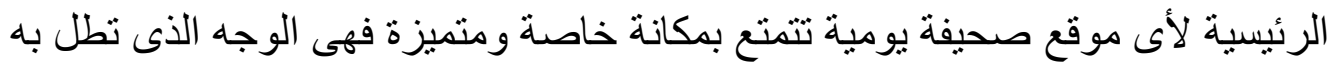

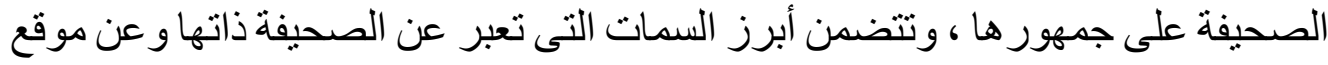
الصحيفة ، وتعطى الانطباع الأول عن شخصية الموقع وخطه التحريرى ، و واتجاهاته وأيديولوجياته السياسية .

\section{أولاًا : مشكلة الدر اسة وأهدافهها :}

تحاول الدر اسة التعرف على الأيديولوجيات و التوجهات التى تتبناها مو اقع الصحف

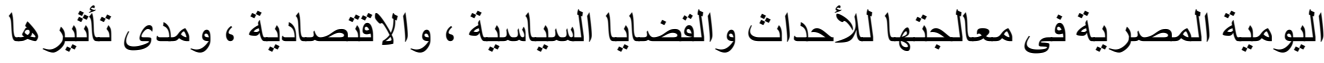

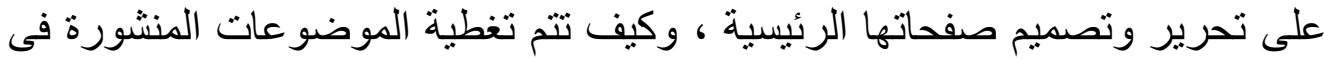

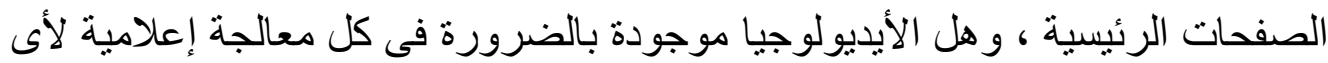

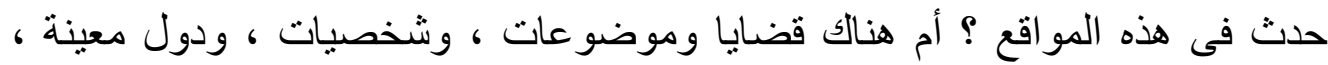

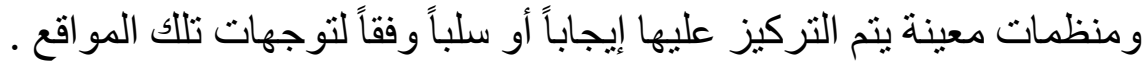

\section{وتهذف هذه الاراسه بشكل رئيسي إلى التعرف على ما يلى :}

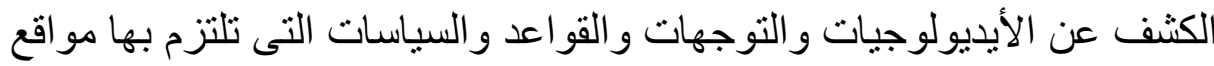
الصحف اليومية المصرية فى نشر موضو عاتها السياسية ، الاقتصادية على صفحاتها

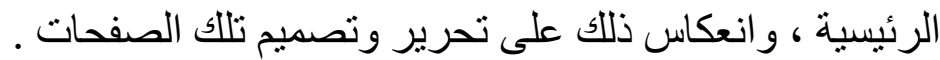

\section{وسنستعرض الأهداف التاليه لتحقيق هذه الأهداف الرئيسية :}

الأهداف التحليلية :

ا ـ الكثف عن طرق معالجة المضامين الإخبارية ، وزو ايا معالجة الموضو عات

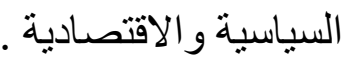

r. التعرف على اتجاه مضمون التغطية الإخبارية وأبعادها ، ومدى تحقيق المعايير

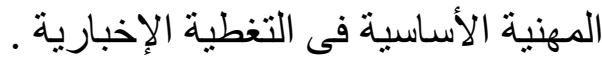

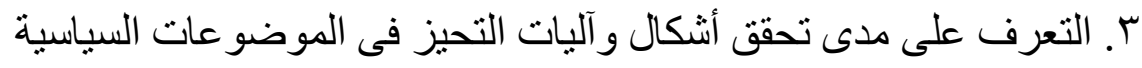
و الاقتصادية .

ع. التعرف على معايير استخدام المصادر المجهلة على الصفحة الرئيسية. ه. تحديد العلاقة بين الأيديولوجيا و الأبعاد التفاعلية والمشاركة فى الصفحة الرئيسية. 
1 ـ ارتباط فترة التحليل بالعديد من الأحداث على الساحة المحلية و الدولية ، و التىى تتطلب

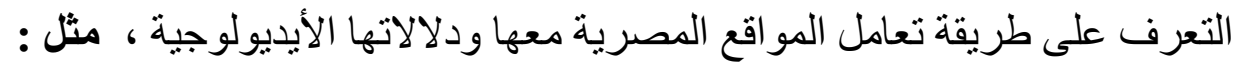

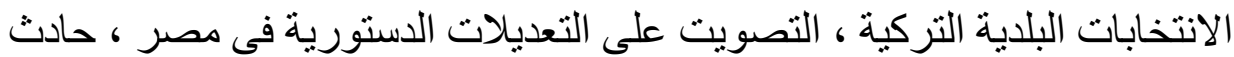

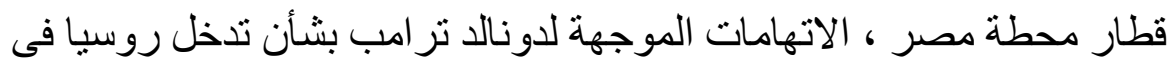

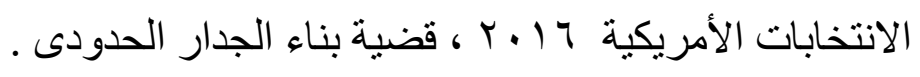

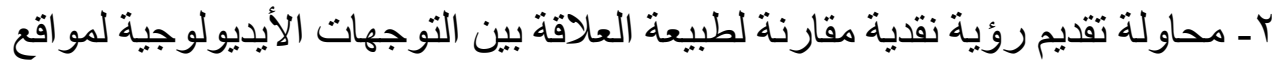

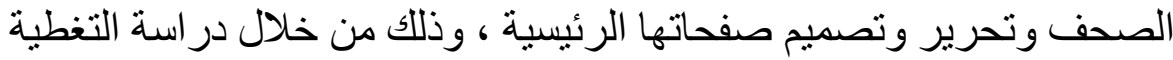

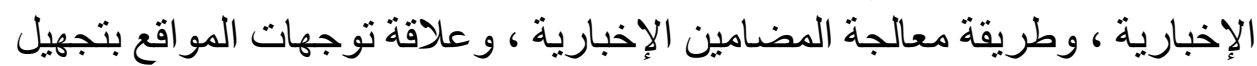

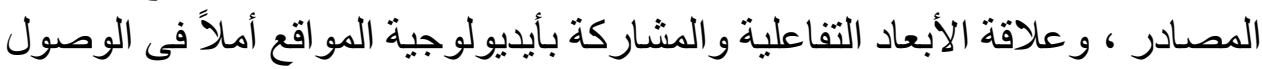

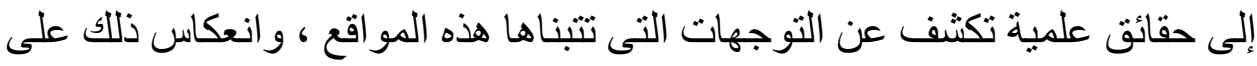
الجانبين التحريرى و التصميمى .

ثُالثاً : تساؤلات الدراسة التحرئ

\section{تسعى الاراسة للإجابة عن تساؤل رئيسى يتمثل فى :}

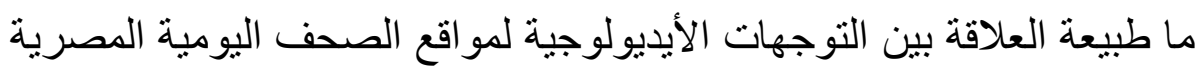

وتحرير وتصميم صفحاتها الرئيسية ؟ لئية التهات

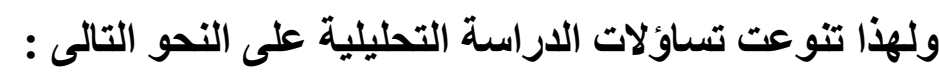

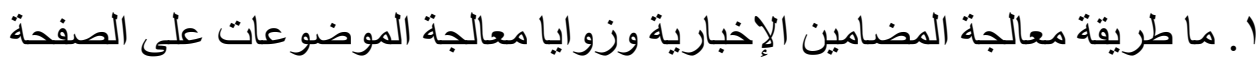

الرئيسية ؟ بانية

r. ما اتجاه مضمون التغطية الإخبارية و أبعادها بالنسبة للموضو عات المنشورة فى

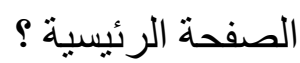

ب. ما مدى تحقق المعايير المهنية الأساسية فى التغطية الإخبارية ؟

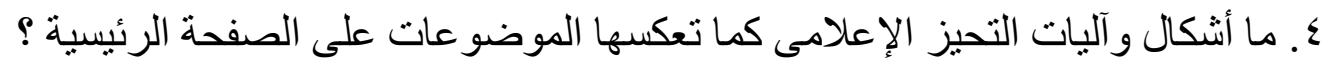

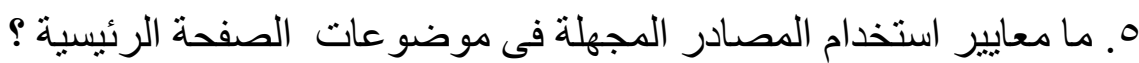

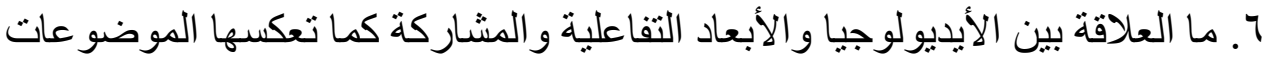

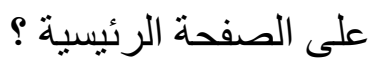

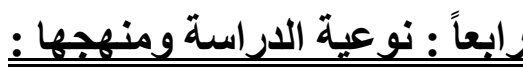

تتنمى هذه الدراسة إلى الدراسات الوصفية التحليلية فى محاولة للكثف عن الته

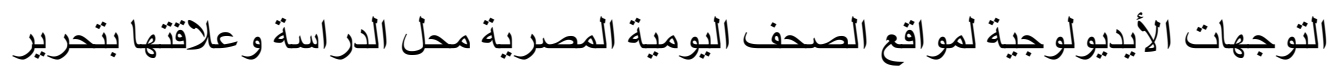

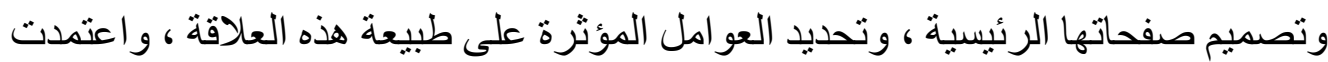

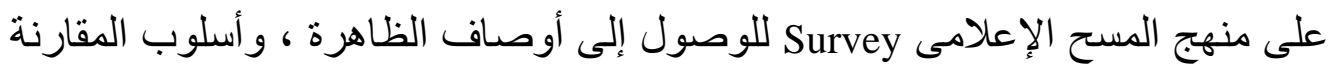

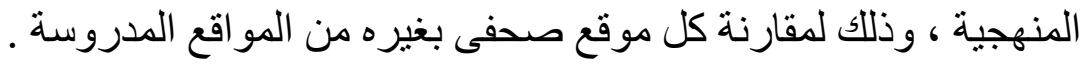

1ـ العينة ومجتمع الدراسة :

تشتمل عينة الدر اسة التحليلية على تحيل الأخبار ، و الأشكال الإخبارية على الصفحة 
الرئيسية فى ثلاثة مواقع مصرية هى (بوابة أخبار اليوم الإلكترونية - بوابة الوفد

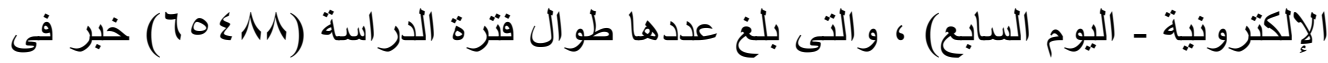

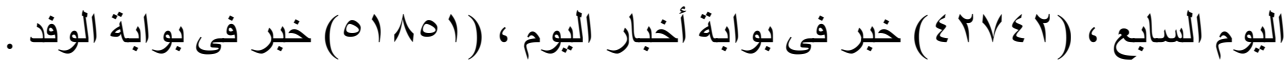

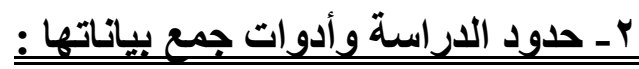

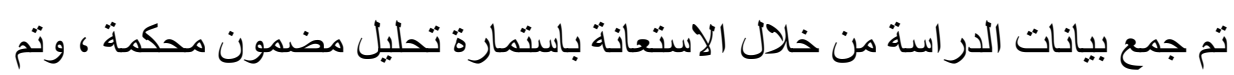

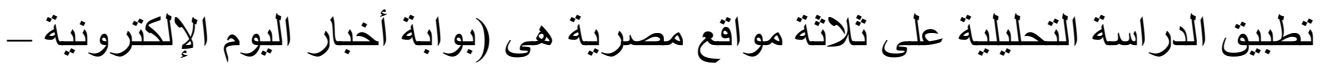

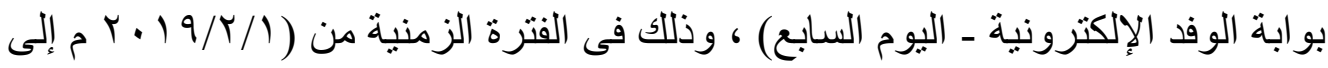

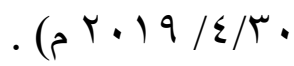

\section{خامساً : مصطلحات الاراسة : (المفاهيب الإجرائية) ؛}

أـ أيديولوجيا الإعلام : مجمو عة من الأفكار يتم التعبير عنها من خلال العملية الاتصالية

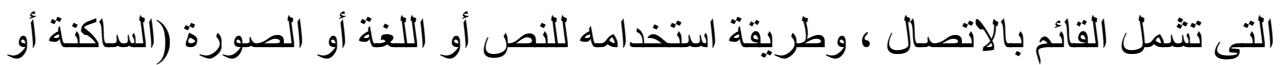

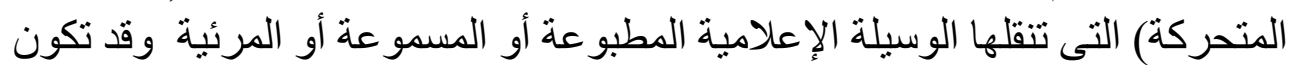

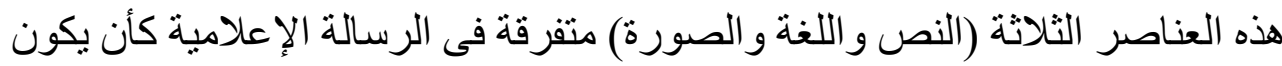

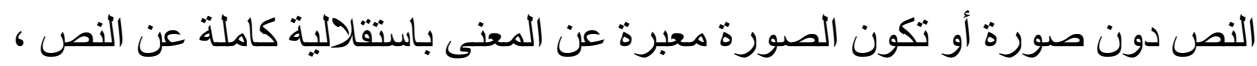

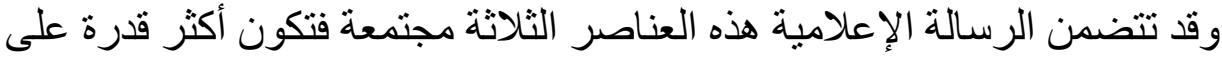
الإقتاع و التأثير فى جمهور الوسيلة الإعلامية (؟).

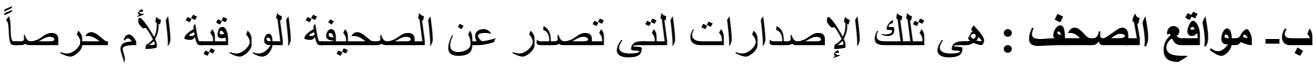

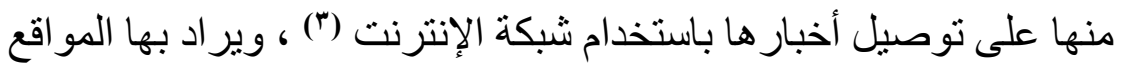
الإلكترونية للصحف المصرية و الأجنبية اليومية على شبكة الإنترنت .

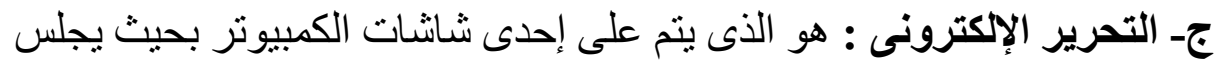

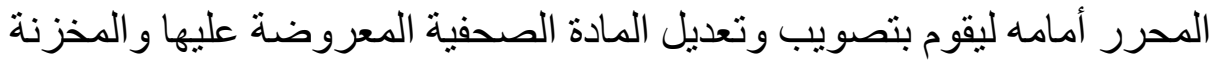

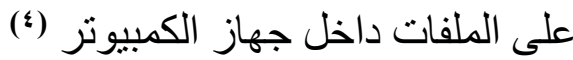

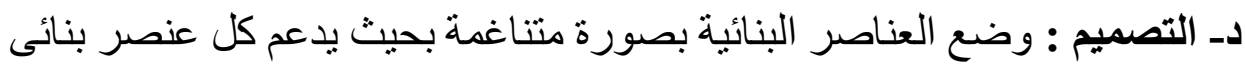

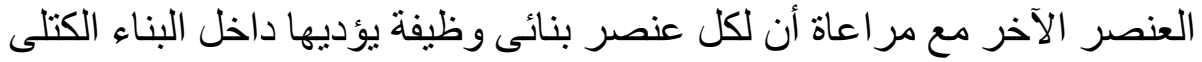

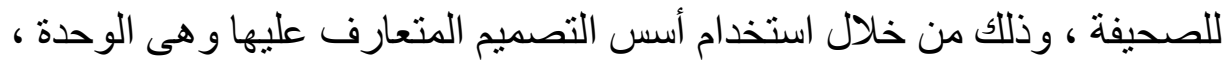

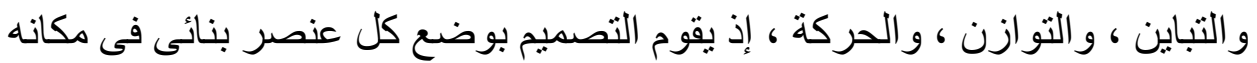

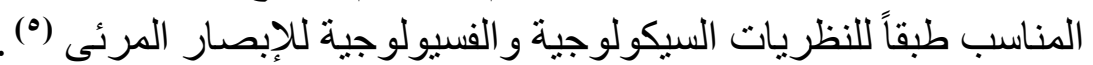

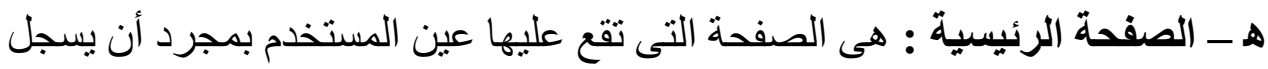

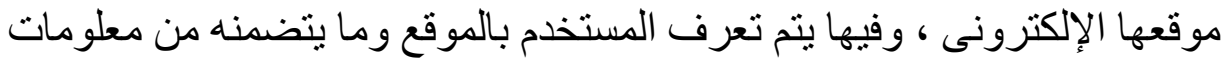

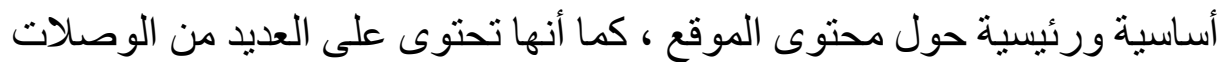

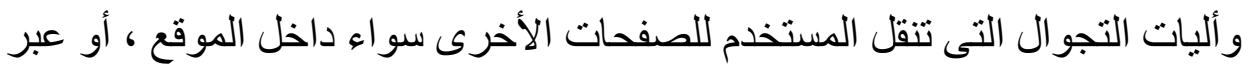

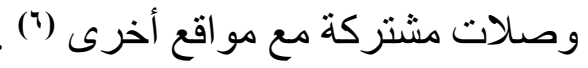

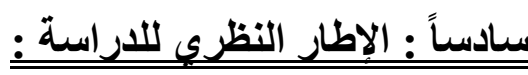

هناك تفاوت كبير بين وسائل الإعلام المختلفة فى تغطينها للأحداث وفقاً لرؤيتها التى يجسدها القائم بالاتصال ، أو لسياستها وأهدافها وتوجهاتها ، و ويينى الإعلاميون 
رسائلهم على مرجعياتهم الثقافية ومعتقداتهم الاجتماعية ، وفى أحيان أخرى على مو اقفهم

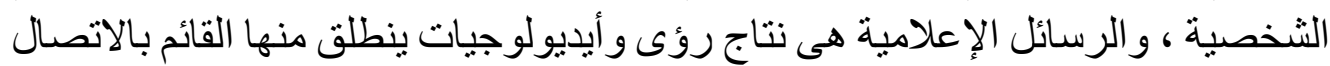

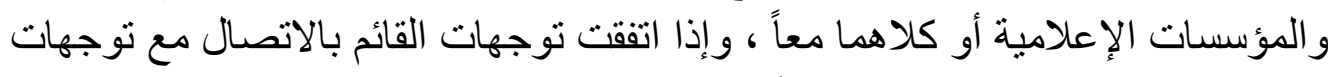

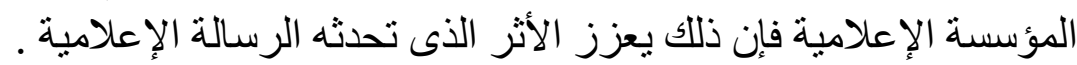

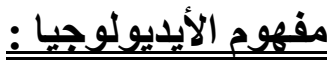

يعرف Lilleker الأيديولوجيا على أنها "مجمو عة من الأفكار و المعتقدات التى ولى

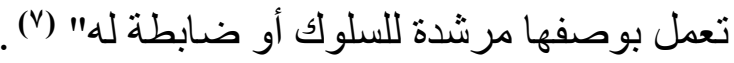

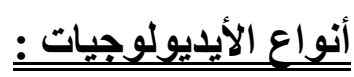
تقسم الكثير من الدراسات الأيديولوجيا إلى الأنواع التالية :

\section{أـ الأيديولوجيا المهيمنة Dominant Ideology}

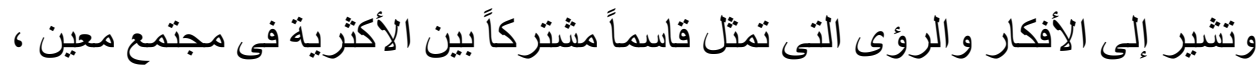

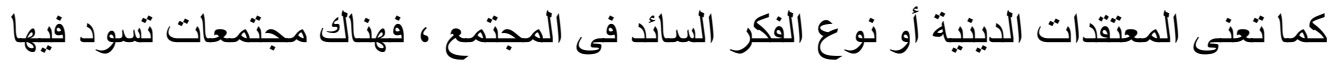
المتقدات الدينية مثل : الإسلام ، و اليهودية ، و النصر انية ، ولئية ، والعلمانية .

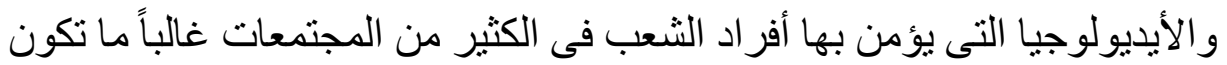

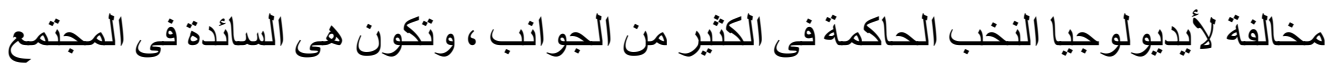
حتى وإن اختلفت عن أيديولوجيا النخبة . بـ أبديولوجيا النخب السباسبة :

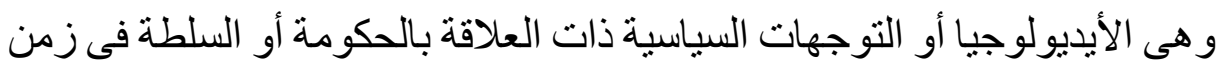

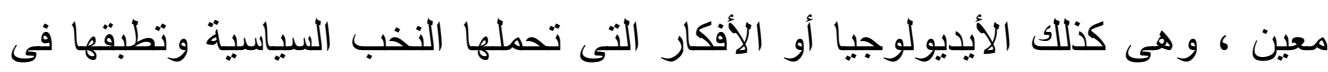

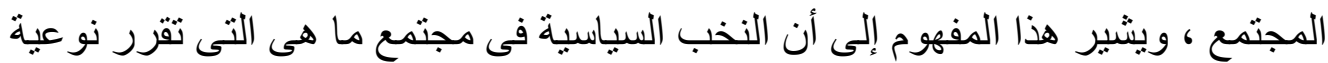

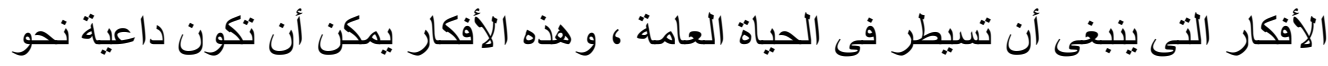

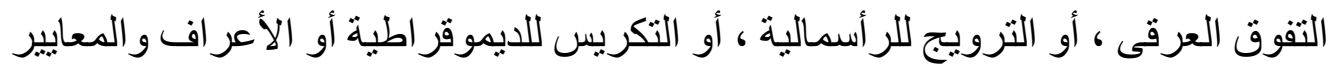

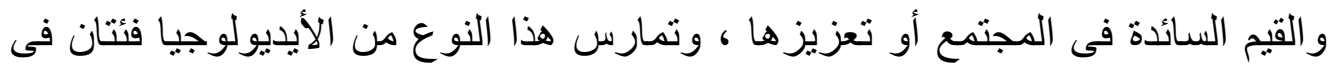

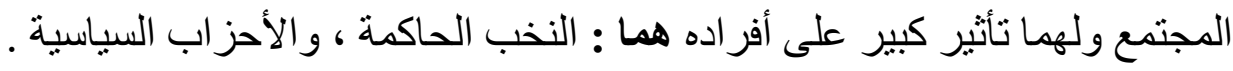

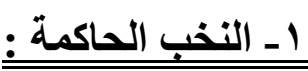

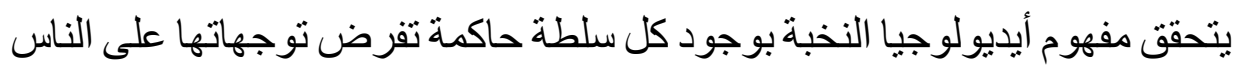

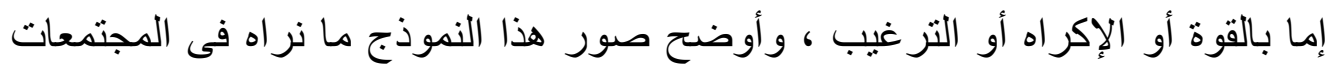

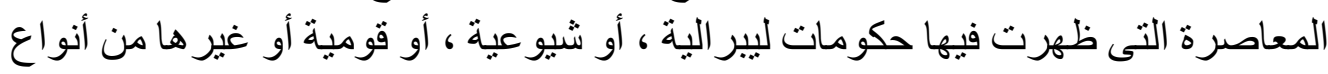

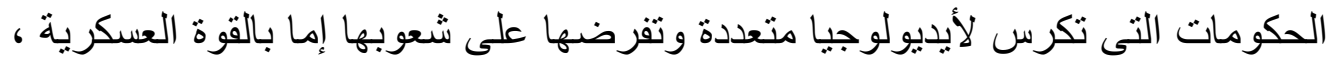

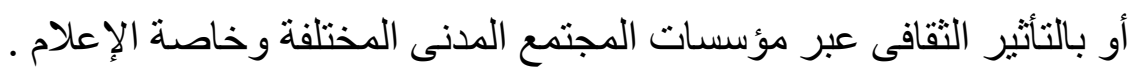

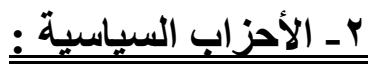
وهى الفئة الثانية من النخب التى تسعى إلى الترويج لقيم معينة قد تتفق مع القيم

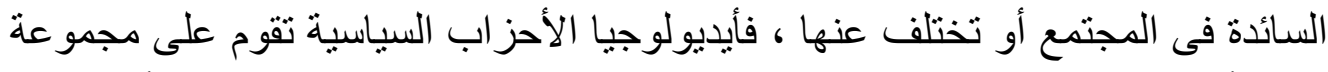

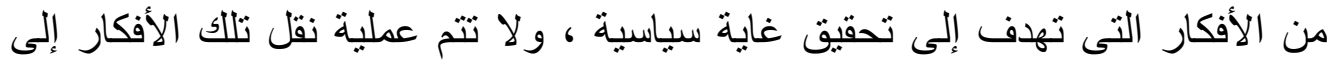


الجماهير لتحقيق ذلك الهدف أو الغاية السياسية إلا باستخدام أدوات التعبير الجماهيرى

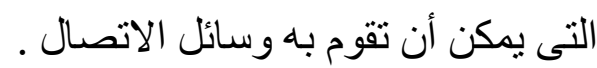

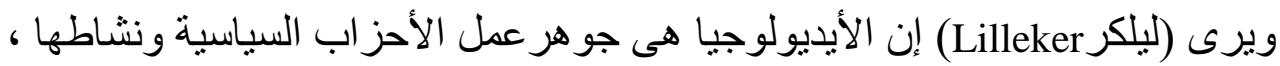

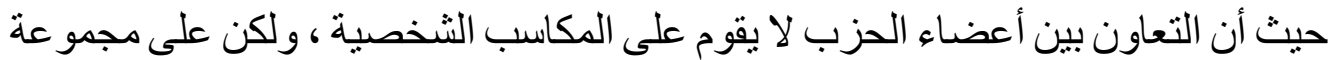

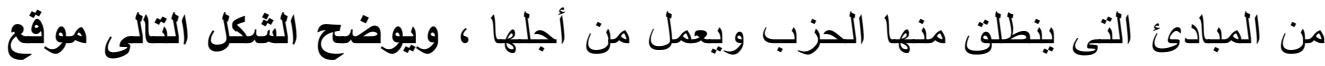
الأيديولوجيا من الحزب النيادئ السياسى (^) :

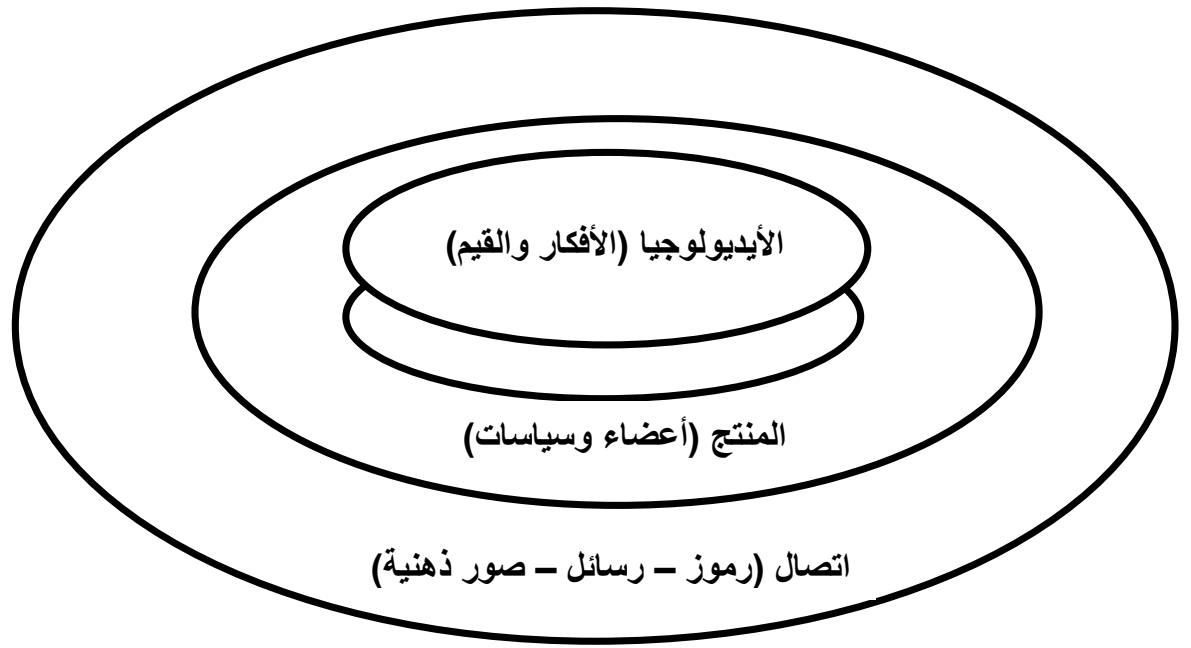

يلاحظ من الثكل السابق أن :

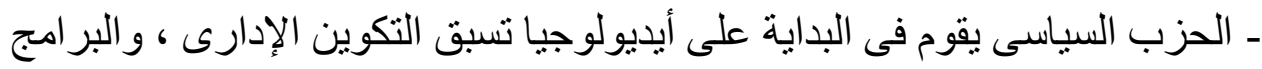

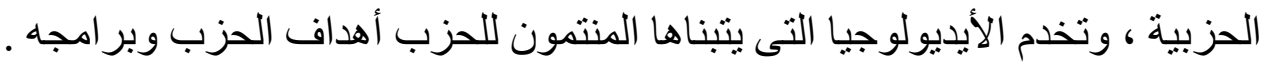

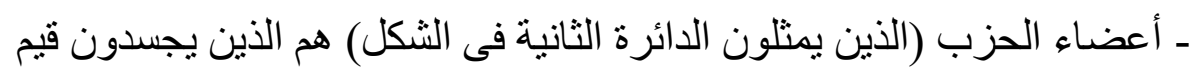

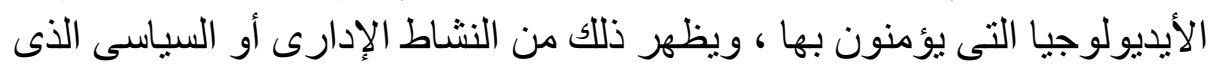

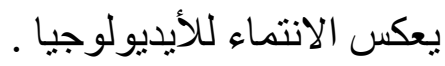

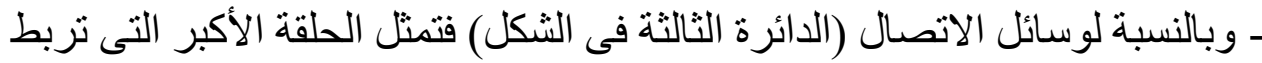

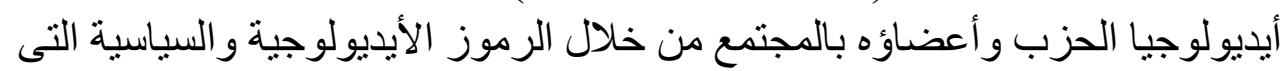

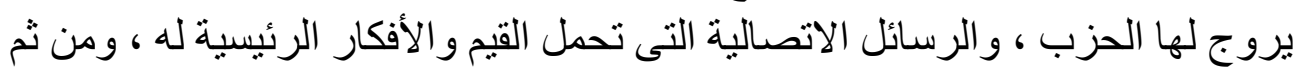

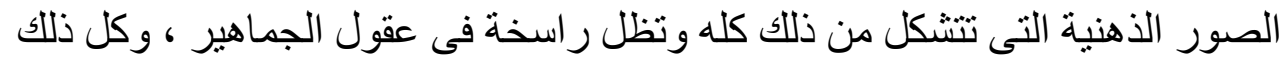

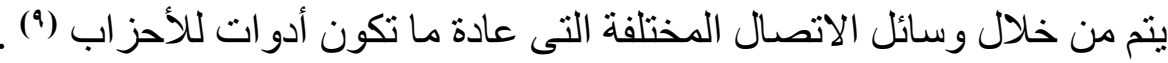

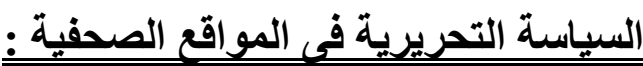

هناك معايير تؤثر فى السياسة التحريرية للموقع الصحفى كالتالى :

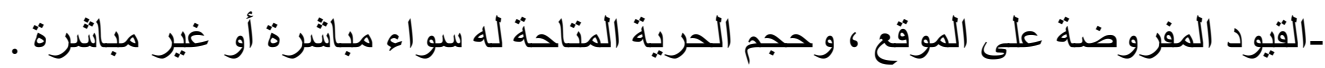
ـ المعايير التى تحكم السلوك الاتصالى بالمجتمع تبعاً لسمات هذا المجتمع وحاجته . ـ ـ ـعايير السلوك المهنى ومو اثيق أخلاقيات المهنة . لمائ.

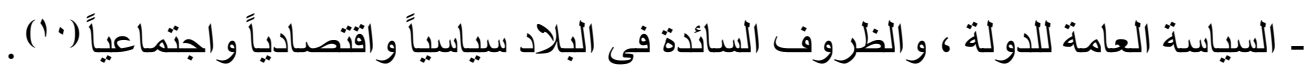

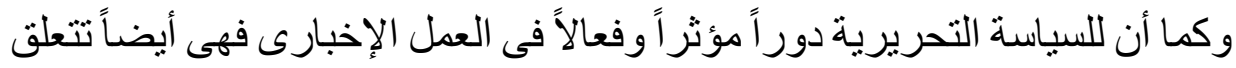
بشكل وثيق بعناصر ومر احل النظام الاتصالى ككل ، وذلك كما ليلى : 
ـ ـ مصدر الرسالة (المعلومات) : وهى المادة التى يتألف منها الاتصال .

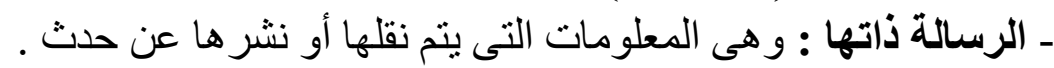
ـ ـ الوسيلة : وهى التى تنقل وتنشر من خلالها الرسالة إلى المستقبل .

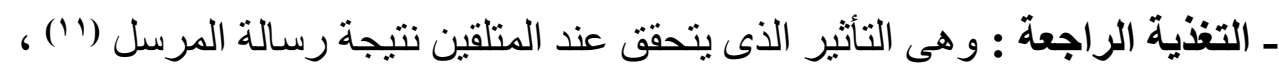

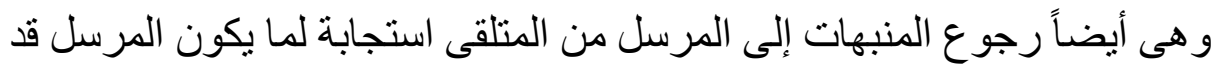

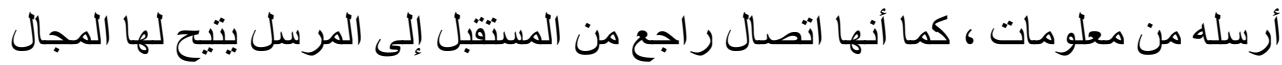

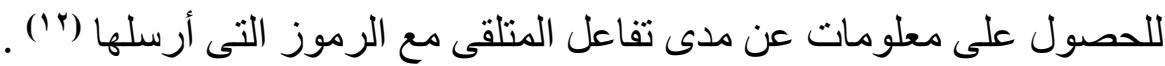

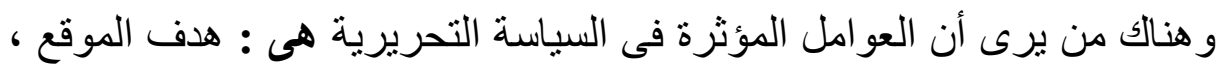

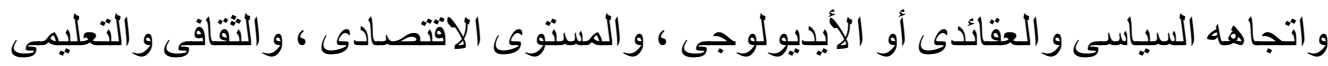

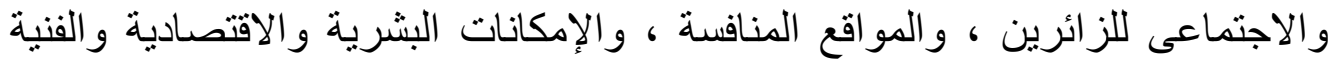

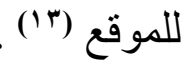

وهناك علاقة ارتباطية بين القيم الإخبارية التى نهتم بها مواقع الصحف في

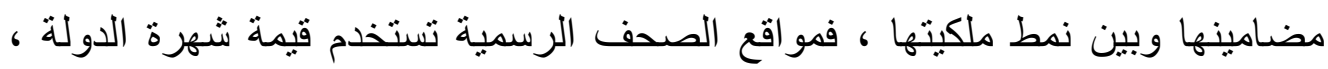

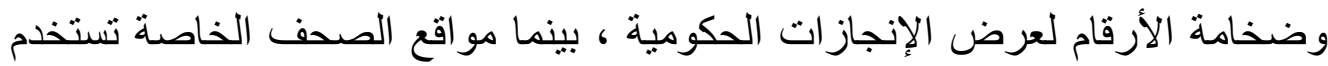

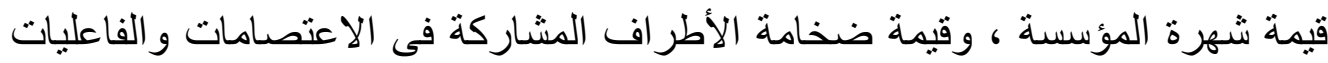

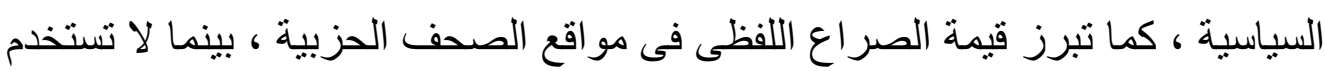

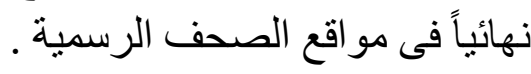

\section{ويكون تأثير السياسة التحريرية فى القيم الإخبارية فى المواقع الصحفية من خلال :}

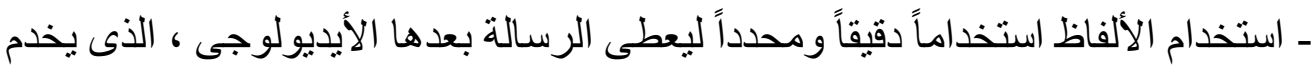

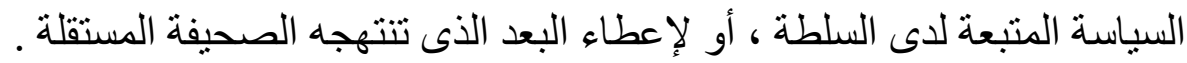

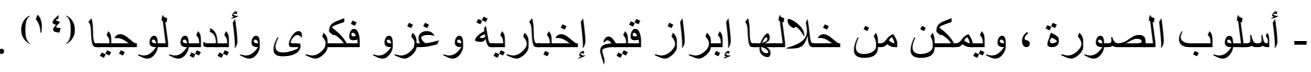

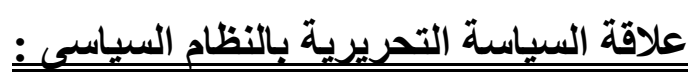
أـ سباسة الدولة:

تعد السياسة العامة للادولة ، و الظروف السياسية السائدة داخلها من العو امل المؤثرة

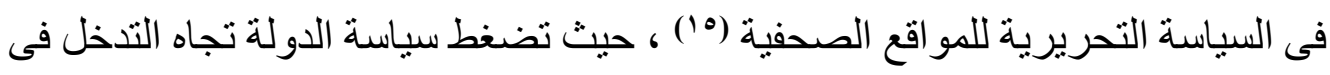

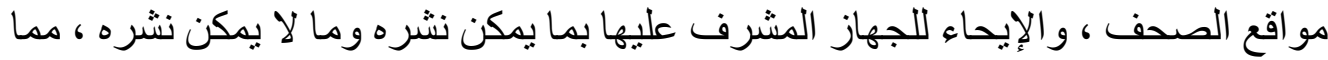

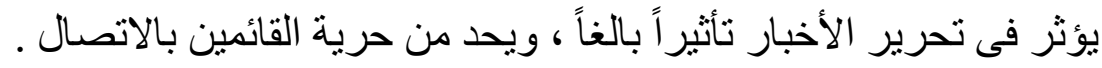

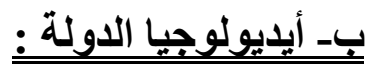

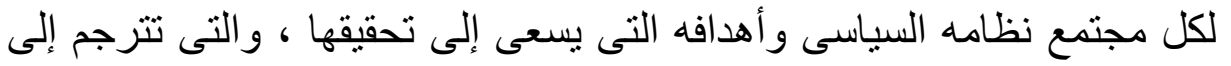

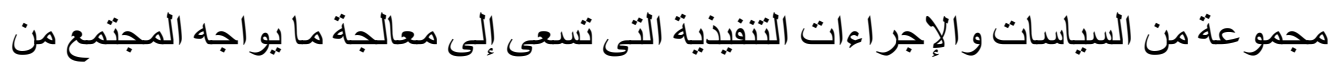

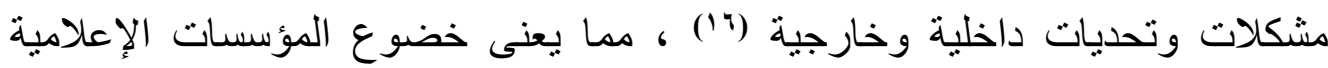

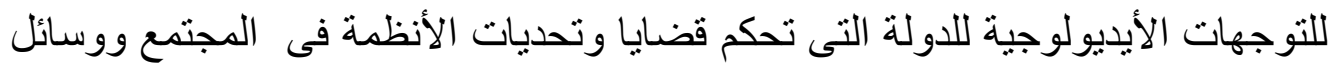

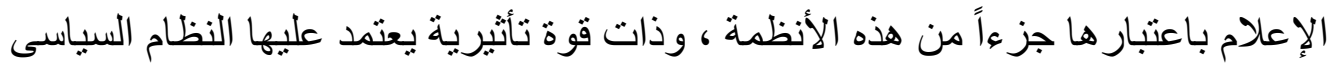

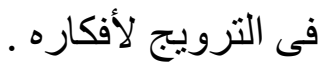




\section{ج- السباسة الإعلامبة للاولة:}

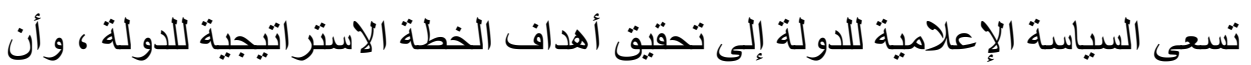

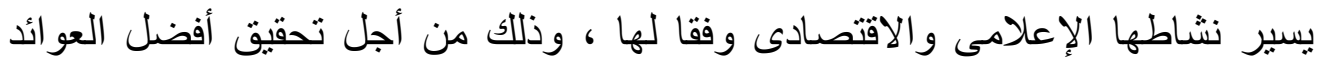

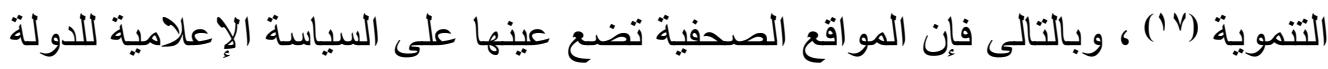
عندما تحدد سياستها التحريرية ، وموقفها من الأحداث و القضايا المستجدة .

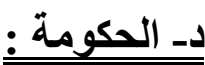

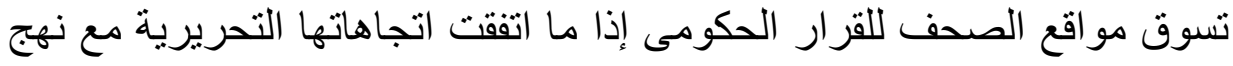

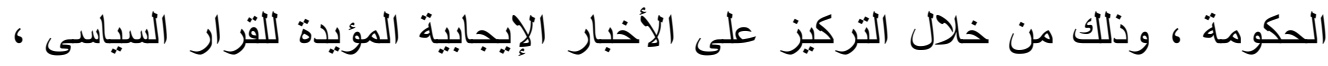

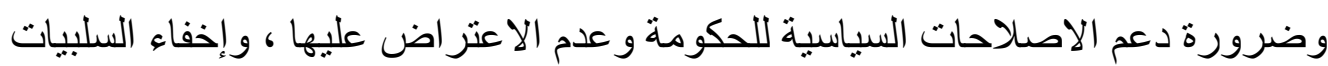

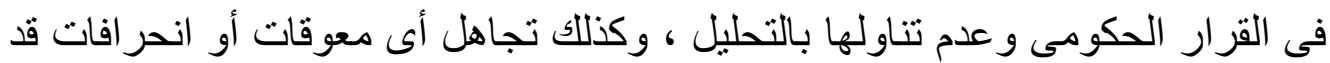
تتعارض مع توجهات الحكومة .

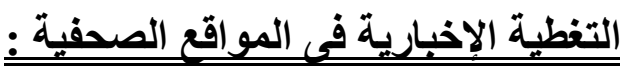

مفهوم التغطبة الإخبارية :

ـ هى العملية الصحفية التى تتضمن مجمو عة الخطو ات التى يقوم من خلالها المحرر

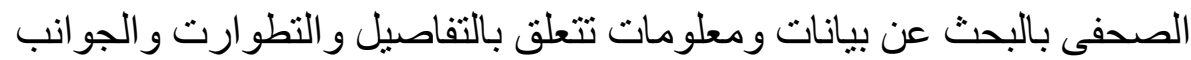

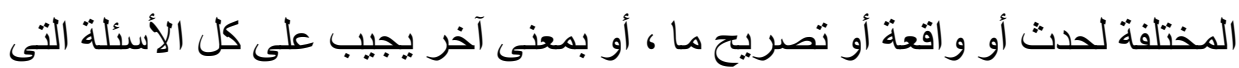
قد تتبادر إلى ذهن القارئ بشأن هذه الو اقعة أو الحدث أو أو التصريح ، ثم بقيّم هذه الته

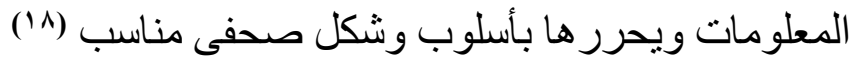

ـ و هى أيضاً "الإحاطة بكل تفاصيل الحدث الهام الذى يستحق النشر في الجريدة أو

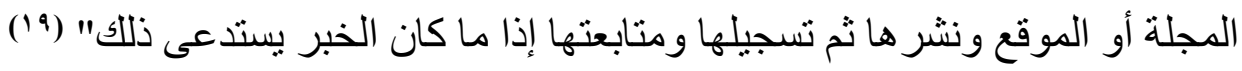

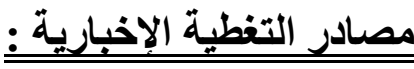

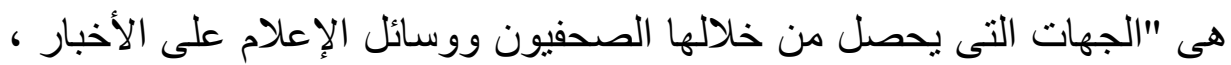

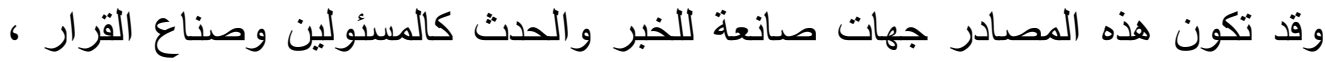

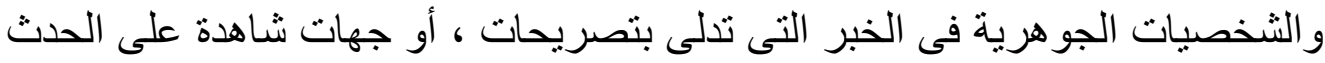

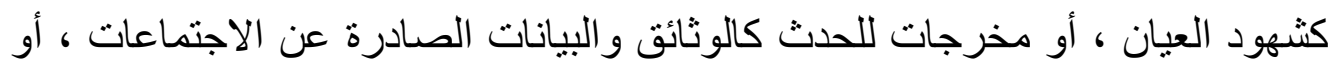

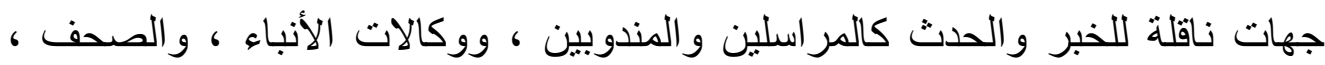

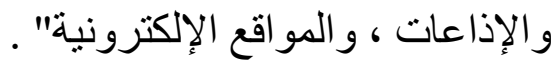

ومن خلال هذا المفهوم يتبين أن مفهوم المصادر الإخبارية متعدد الأوجه : - جهات صانعة ، أو مشاركة فى الحدث ، أو مرتبطة به ، أو ناتجة عنه ويمكن تسميتها

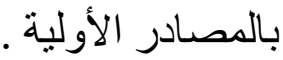

- جهات ناقلة للحدث مثل المر اسلين ، ووكالات الأنباء ، ويمكن تسميتها بالمصادر

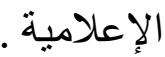

ـ المصادر الأولية قد تكون مصادر حية (كالثخصيات و الجهات) ، و وهى إما أن تكون رسمية أو غير رسمية ، وقد تكون مصادر وثائقية (كالبيانات و الوثائق) . 
ـ المصادر الإعلامية قد تكون داخلية "ذاتية" (من داخل الموقع كالمر اسل والمندوب) ، أو خارجية "عامة" مثل وكالات الأنباء . الأل

\section{المبادئ الأساسبة في التعامل مع مصادر التغطية الإخبارية التهاء}

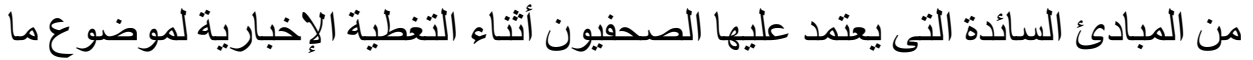

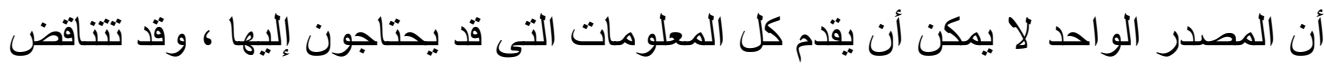

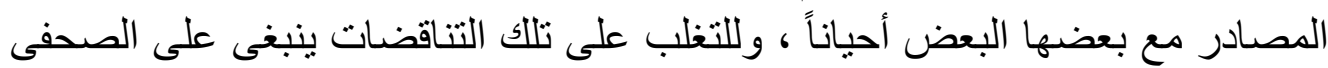

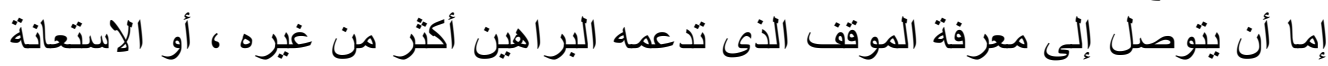

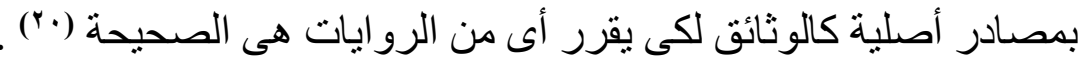

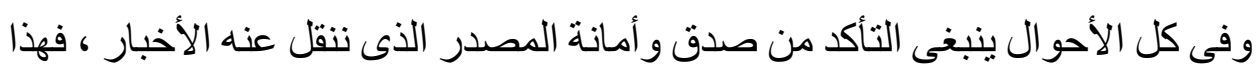

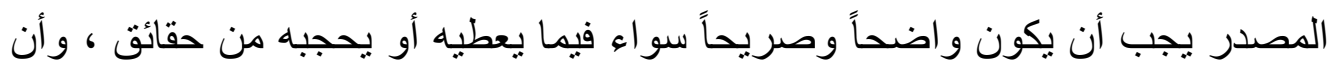

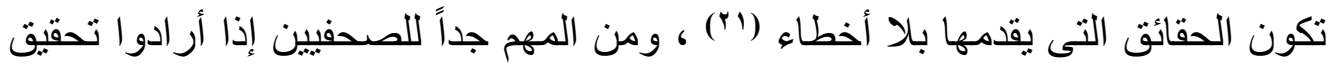

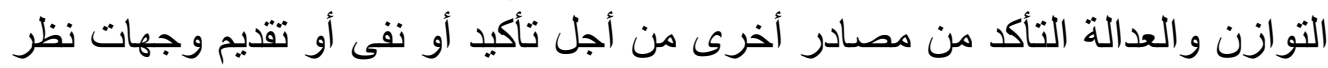

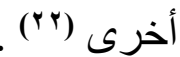

ويعد تعدد المصادر من أهم الأمور ، فالقصة التى تملك مصدر اً واحداً متحدثاً فيها

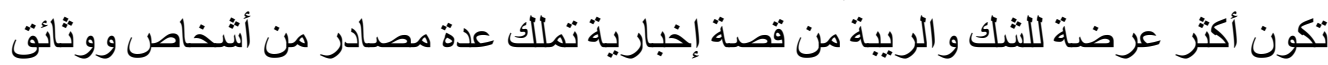

وبيانات (riT)

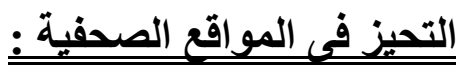

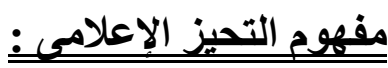

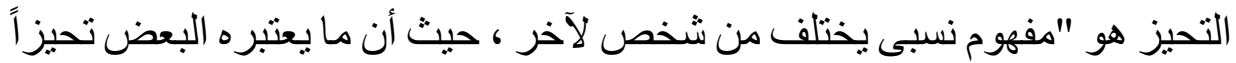

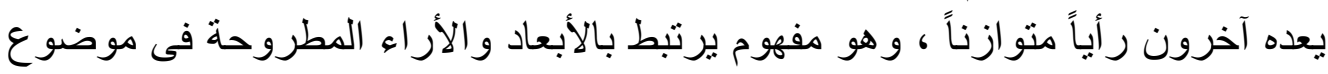

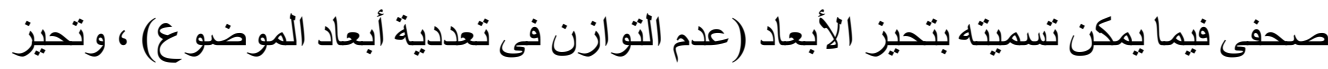

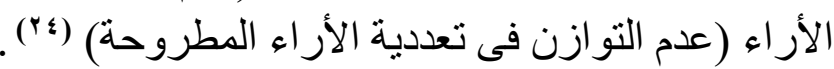

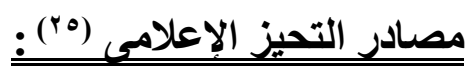

أولهما : التحيز الأيديولوجى : حيث تعدد وسائل الإعلام عبر الزمن للتأثير فى معارف

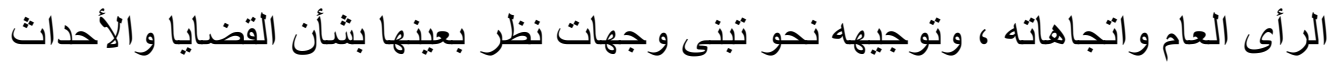

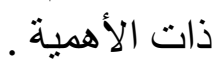

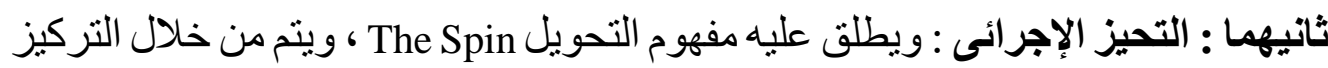

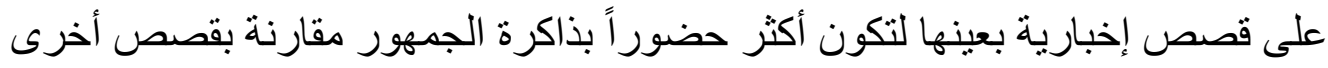

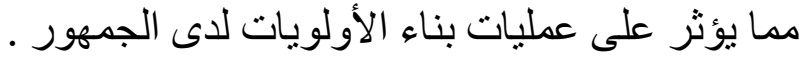

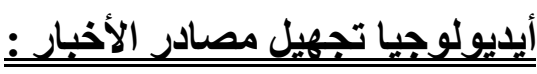

هناك أهمية بالغة للاعتماد على الهصادر الدجهلة في وسائل الإعلام بالنسبة للتغطية التهية

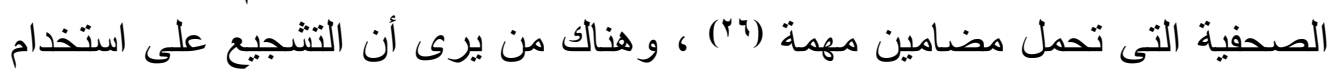

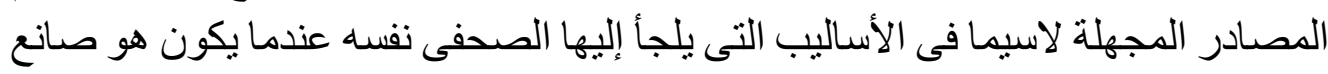

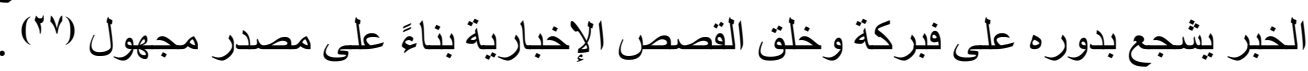


إن وسائل الإعلام و الصحفيين يجازفون بمصداقيتهم فى كل مرة بستندون فيها

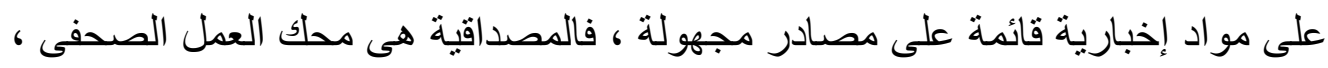

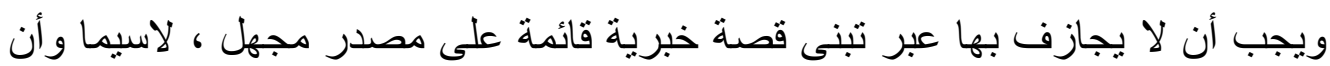

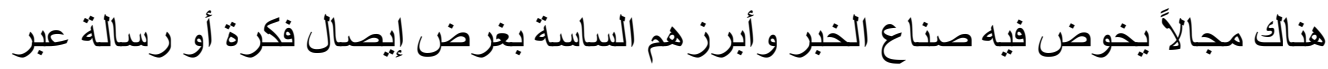

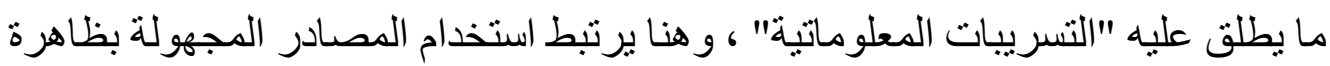

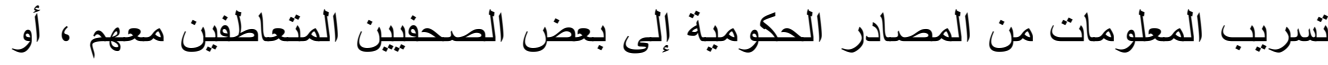

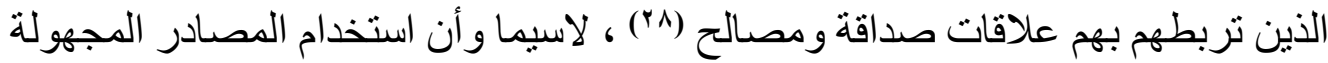

يدو شائعاً جداً فى الأخبار ذات العلاقة بالأنشطة الحكومية (†9) . وقد حددُ (بوينك) سبع قواعد لمساعدة الصحفيين فى تقريز استخدام المصدر

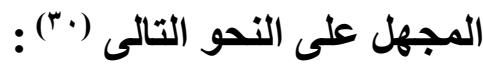
- إذا و عد المصدر بعدم ذكر اسمه فى الخبر فيجب أن يستند إلى مو افقة المحرر أو مدير

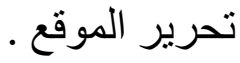
- إن المصدر المجهل يجب استخدامه فقط لسبب و اضح ومبرر . - إن المصدر المجهل يجب استخدامه عندما يكون الخيار الوحيد المتاح لنشر الخبر .

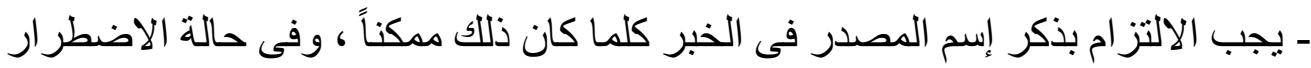

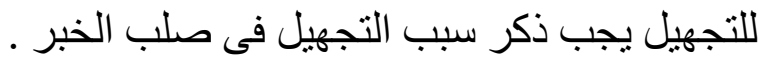

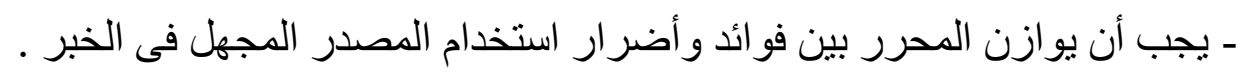

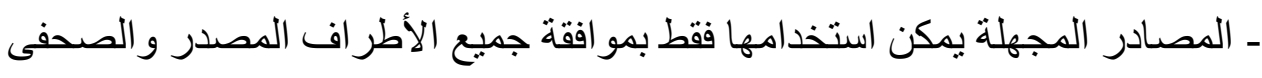
و موقع الصحيفة . - إن استخدام المصدر المجهل يتطلب تأكيد المعلومات من مصدر ثانى . ماهية تصميم المواقع الصحفية :

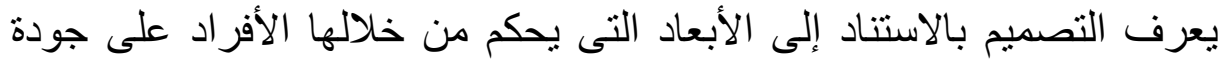

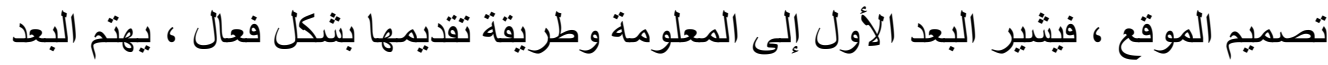

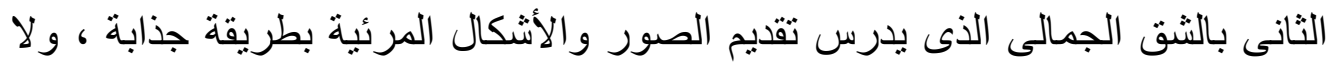

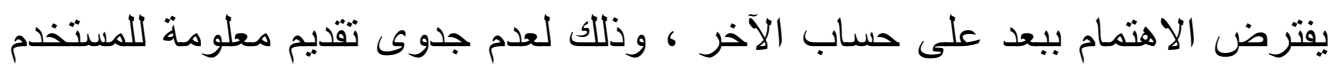

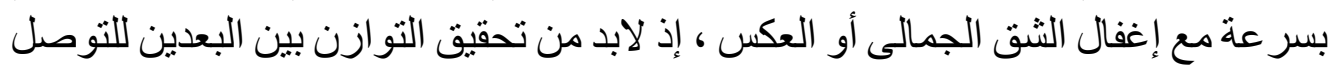

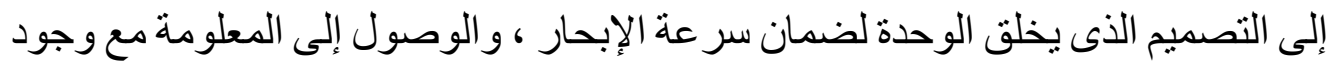

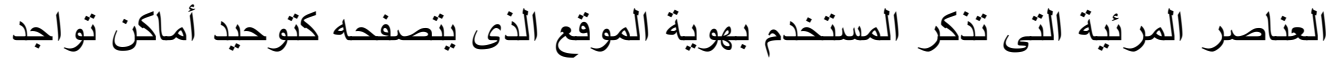

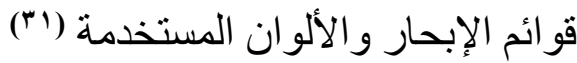

كما يعرف التصميم أيضاً بأنه "طريقة تنظيم وترتيب العناصر البنائية على واجهة التهائه

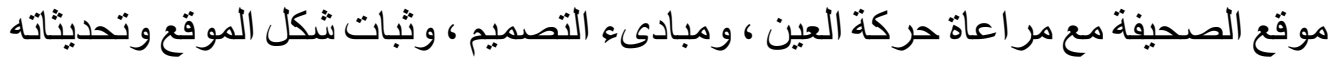

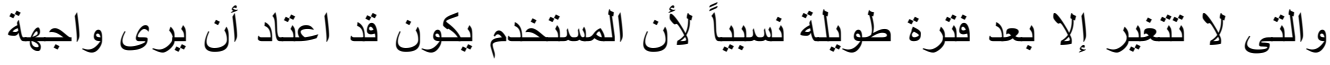

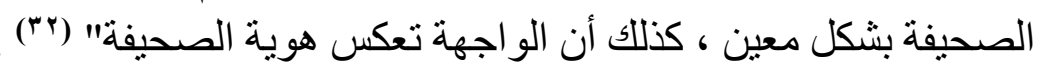
عناصر تصميم المواقع الصحفية :

توجد مجموعة من العناصر التصميمية التى يعتمدها جميع المصممين المحترفين 
فى مختلف تخصصاتهم ، والتى تنطبق على تصميم صفحات الويب خاصة ، ويتمتع كل

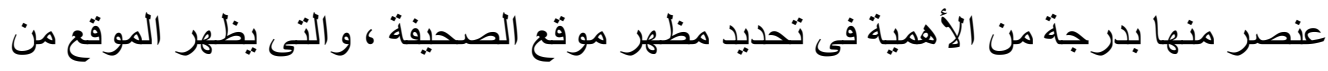

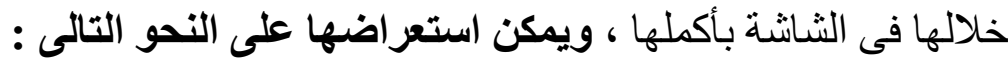

: Space الفراغى

ويشير أيضاً إلى المسافة التى تظهر بين العناصر ، فهو الذى يحدد نقطة بدايةونهاية

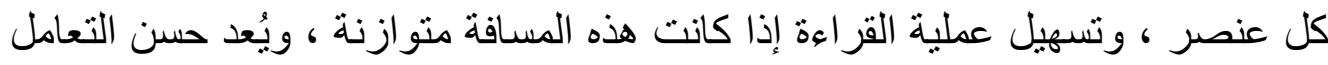

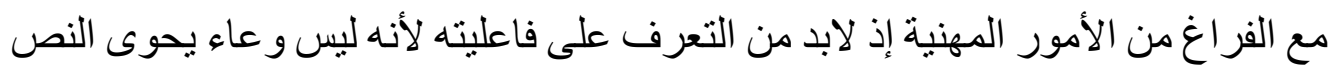

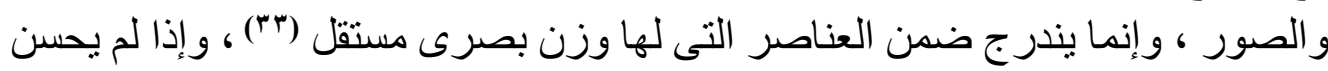

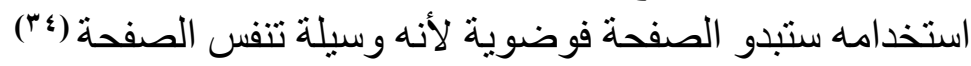

\section{இbackground الخفقية}

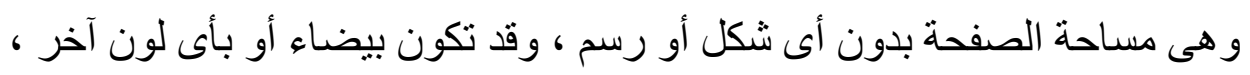

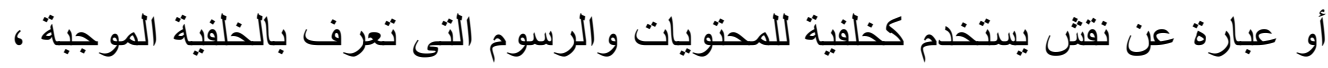

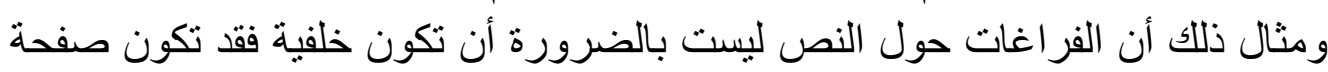

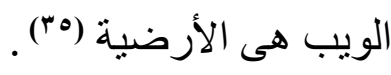

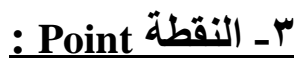

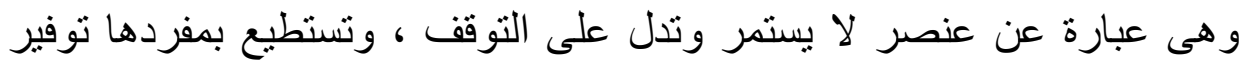

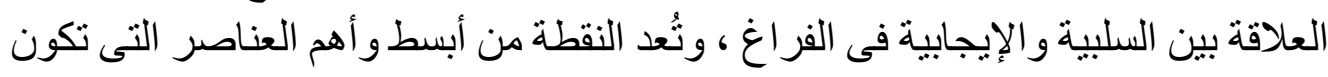

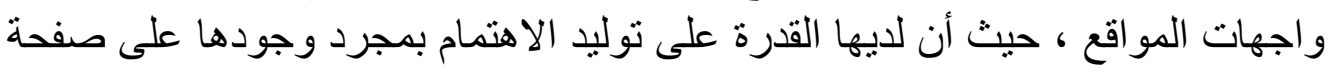

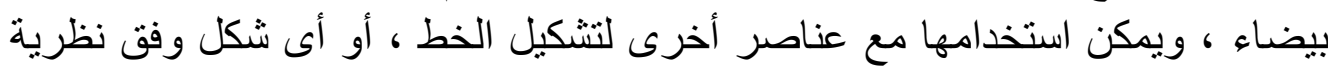

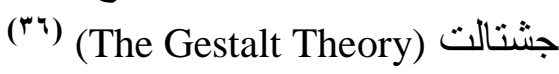

: Line

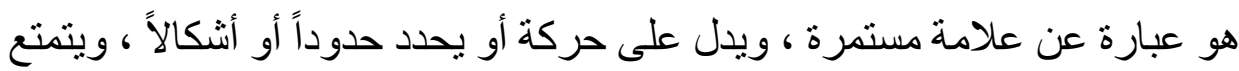

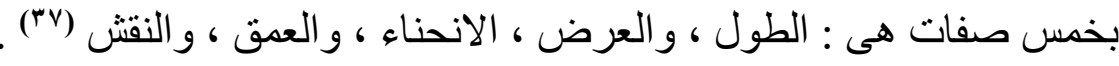

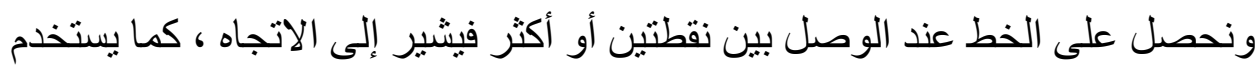

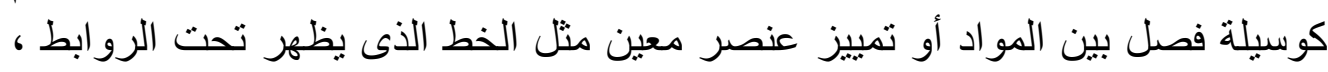

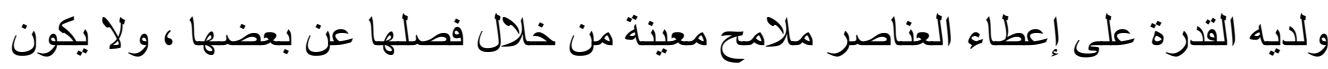

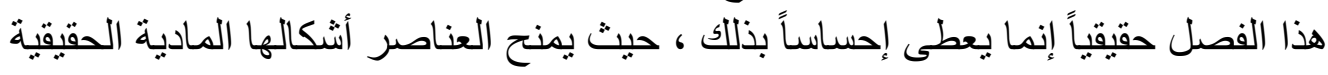

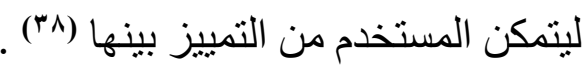

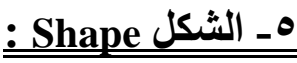

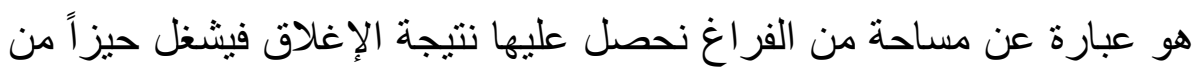

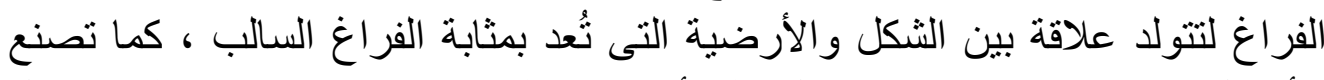

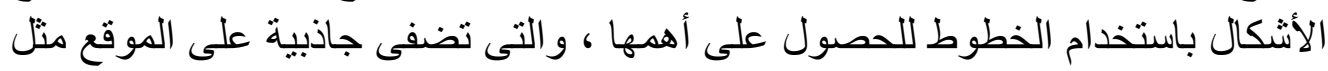

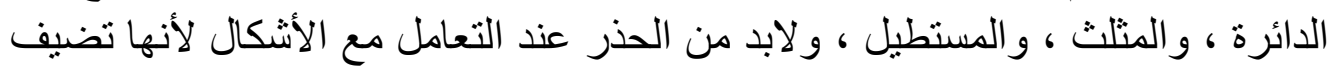

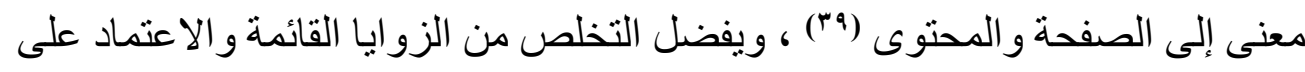


الأشكال ذات الزوايا الدائرية أو المنحنية التى تعطى شعور اً بالر احة (•؛).

\section{7ـ النموذج (Texture) (Pattern) و الملمس"}

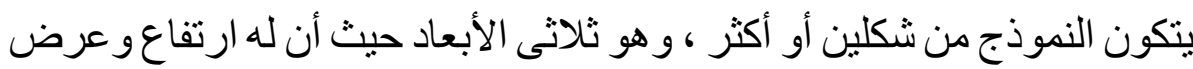

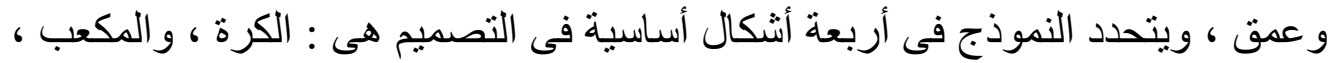

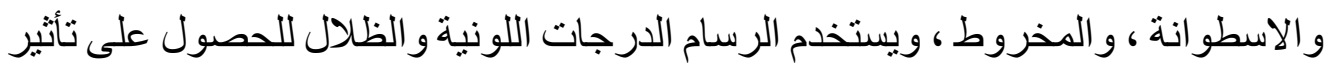

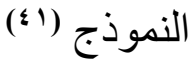

\section{: Multimedia الوسائط المتعددة - V}

ترغب الكثير من المواقع فى إثراء تجربة مستخدميها لتمكنهم من القراءة

و المشاهدة فى نفس الوقت فتضيف مقاطع الفيديو التى تجعل الموقع أكثر حرفية (r؛) ،

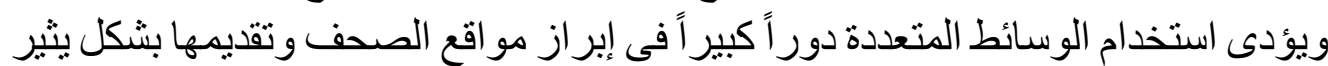

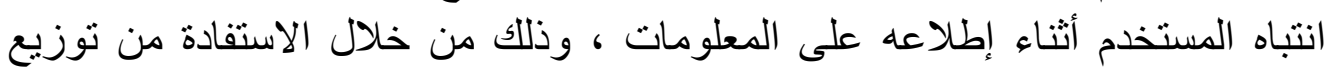

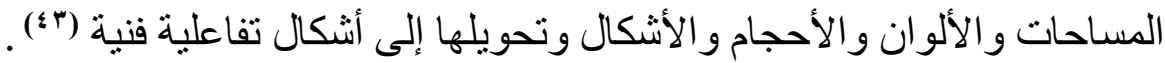

\section{^ــ الأبعاد التفاعلية Interactivity}

تأخذ التفاعلية حيزاً من التصميم ، وينوع مصدمو المواقع من أساليب إبرازها

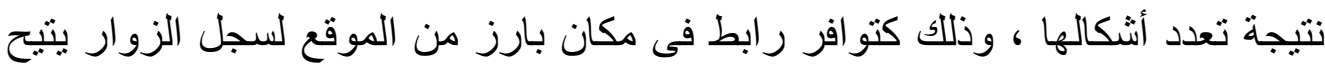

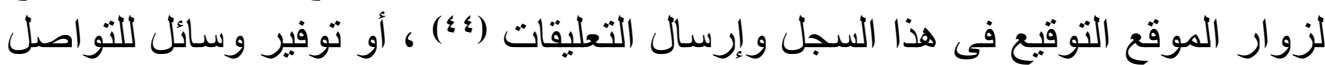
مع القائمين عليه إما من خلال رابط للعناوين البريدية ، أو استخدام النماذج الإلكترونية التى تحتوى على حقول يتم تعبئتها من قبل مستخدم الموقع بالمعلومات التى يريد إئه إرسالها

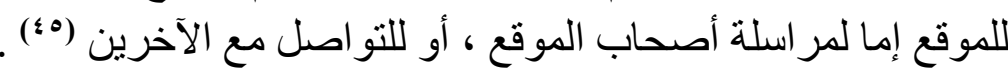
وهناك أيضاً مجموعة من العناصر التى ينبغى مراعاتها عند تصميم مواقع

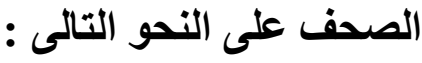

\section{: Icons الأبقونات}

هى صورة صغيرة مستحدثة تمثل فعلاً أو مضموناً معيناً يمكن أن تستخدم بمفردها فتوفر مساحة أو مع الكلمات ، و هنالك بعض الأيقونات معروفة منثل أيقونات الطبع (إرسلها

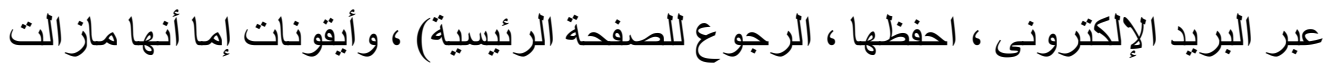

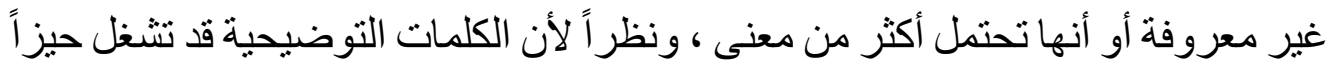

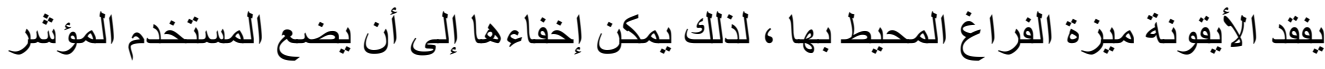

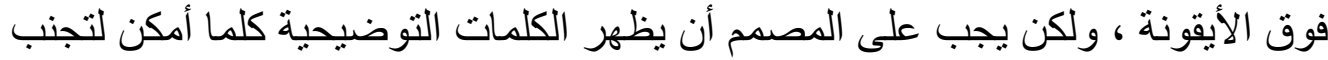

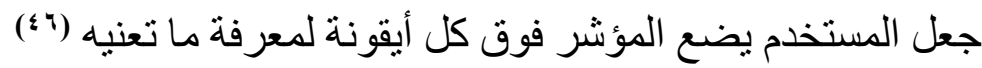

\section{r. بـ القو ائم Menus}

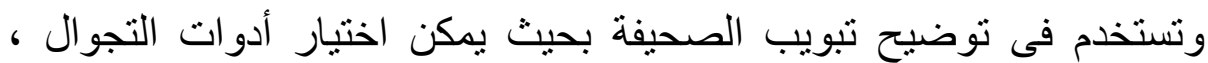

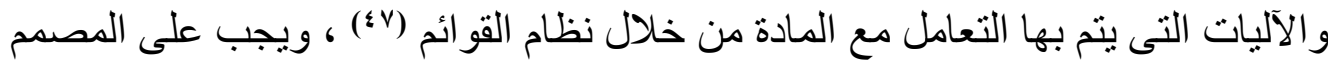

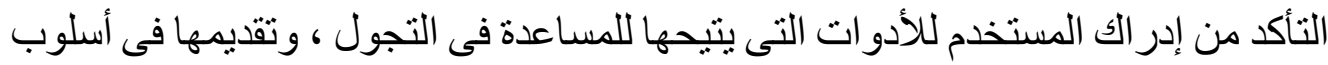
منطقى جذاب (^^) ، وتنقسم القوائم فى مواقع الصحف إلى ما يلى : 


\section{أ- القوائم المنبثقة Popup Menu}

وتظهر للمستخدم بمجردوقوفه بمؤشر الماوس على أحد العناصر الجر افيكية فيتولا منها مجمو عة من القو ائم الفرعية ، ثم تعاود القو ائم الاختفاء بمجرد تحريك مؤشر الماوس لئاس

وتنقسم القو ائم المنبنقة من حيث الاتجاه إلى : القو ائم الأفقية وهى التى تأخذ شكلاً

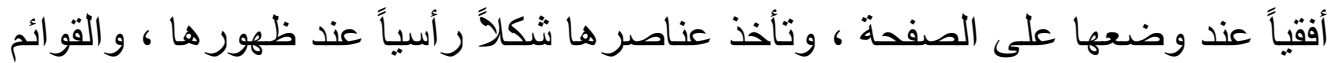

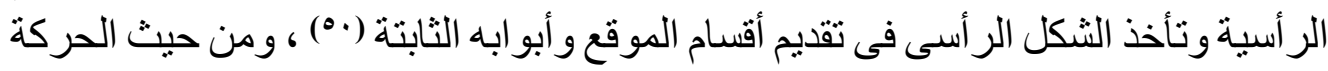

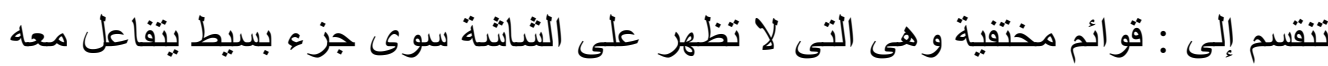

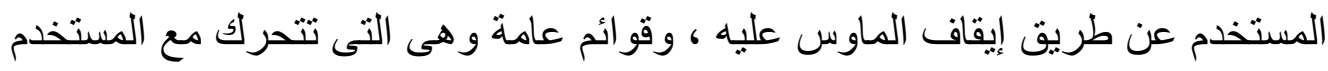
عندما يسحب الصفحة إلى الأسفل ، وقد تكون ظاهرة أو مخفية (10)

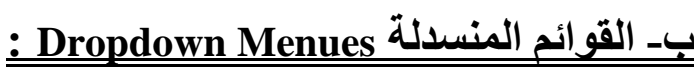

و هى القو ائم ذات الثكل الر أسى الثابت التى لا تتغير نتيجة تفاعل المستخدم معها

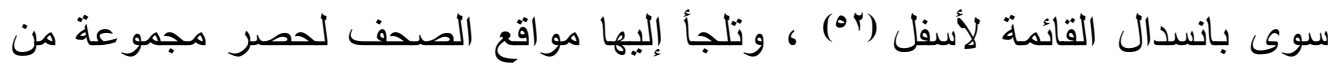
الخيار ات فى مساحة صغيرة من الصفحة حيث تكون الخيار التهات مخفية ويقوم المستخدم بتنشيطها بوضع المؤشر عليها .

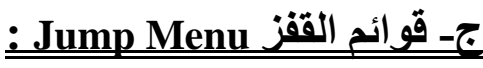

و هى قو ائم ثابتة لا تظهر خيارات أمام المستخدم بالضغط عليها بالماوس و إنما

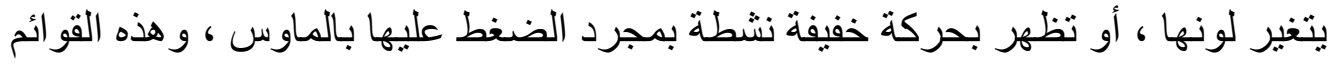

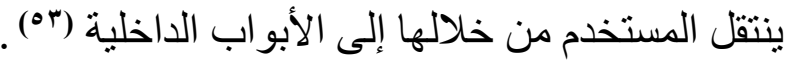

سابعاً : الاراسات السابقة :

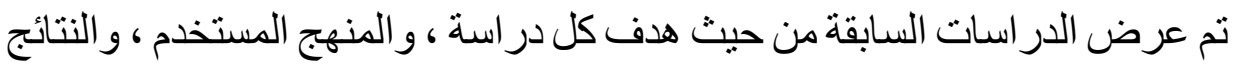
التى توصلت إليها ، وجاءت الاراسات السابقة على النحو التالى :

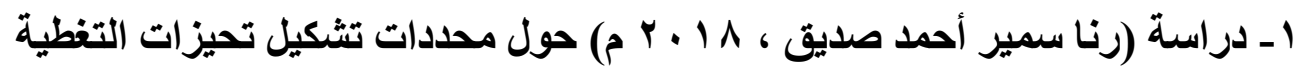

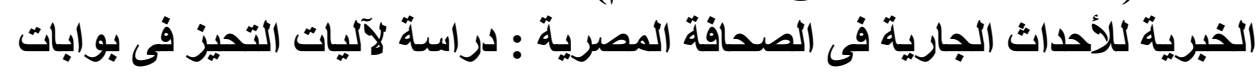

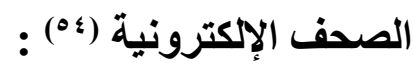

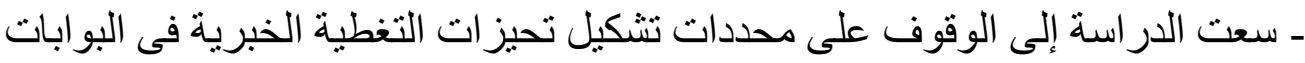

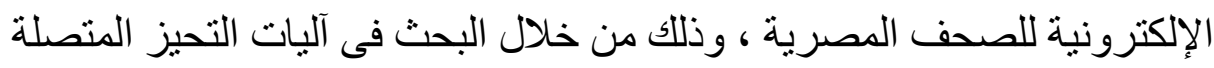

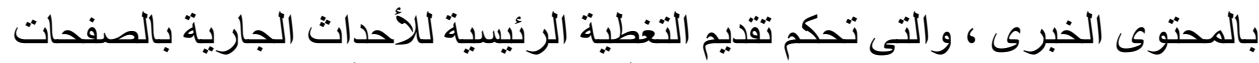
الرئيسية لهذه البوابات ، وتوصلت الاراسة إلى النتائج التالية :

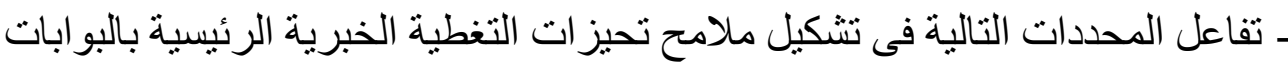

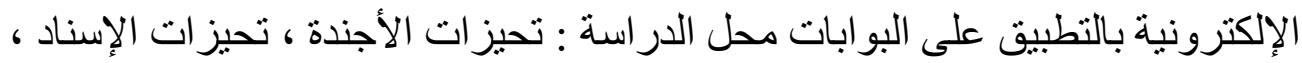

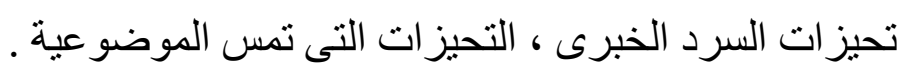

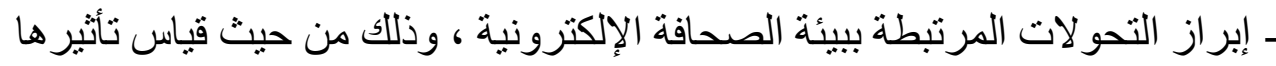

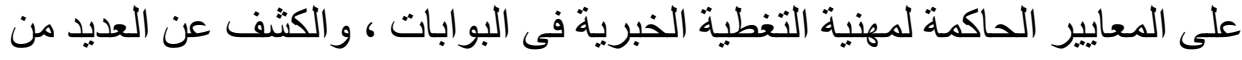
العو امل الأخرى المشكلة للتحيز الإخبارى . 


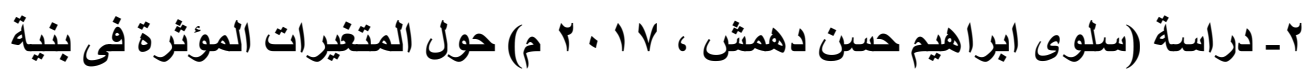

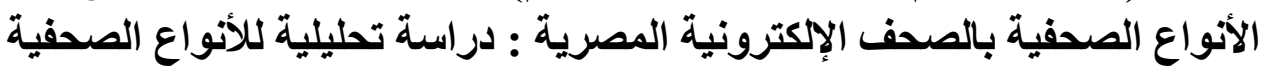

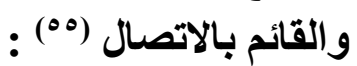

ـ هدفت الدر اسة إلى رصد وتحليل العو امل التنظيمية و الإدارية داخل المؤسسة الصحفية

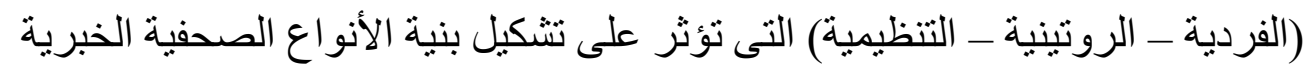

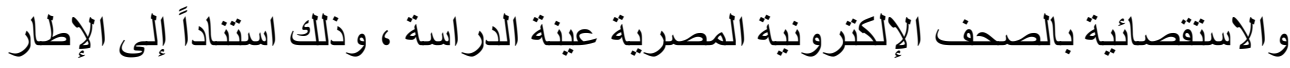

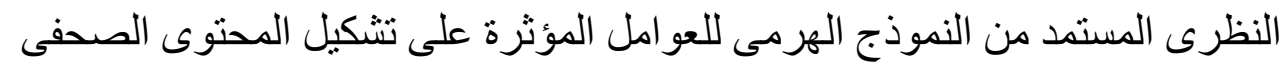

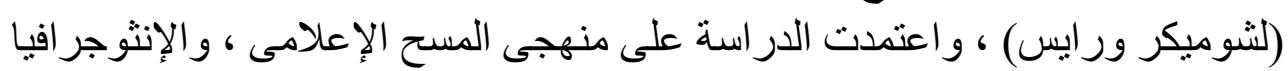

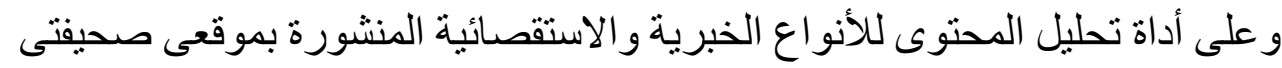

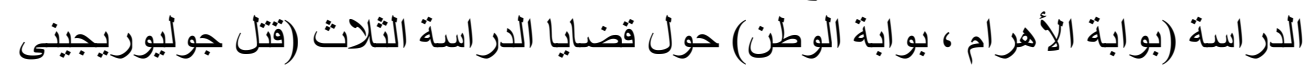

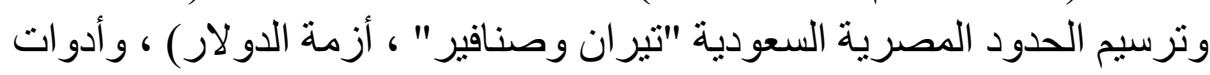

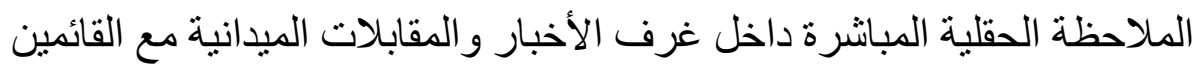

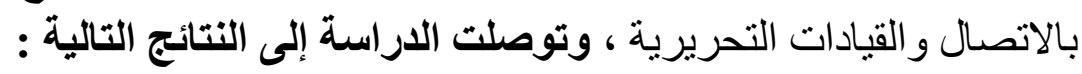

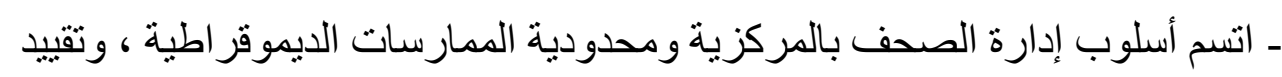

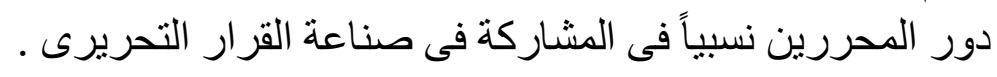

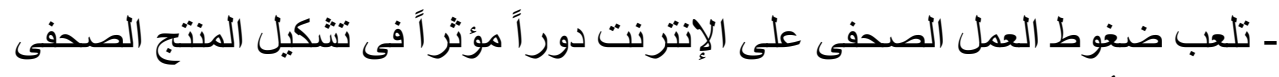

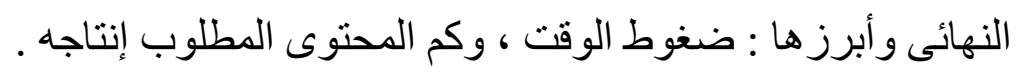

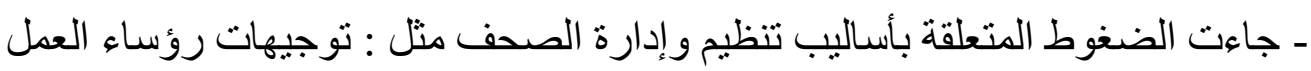

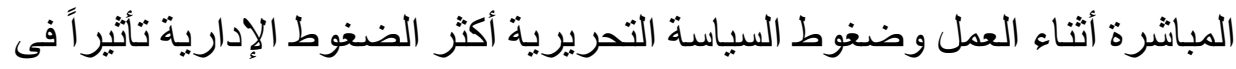

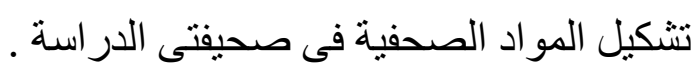

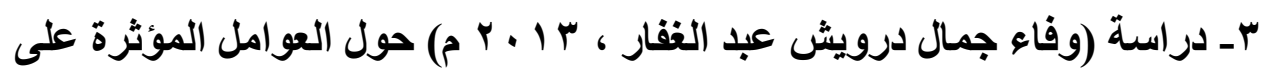

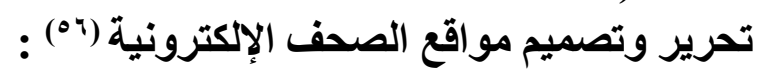

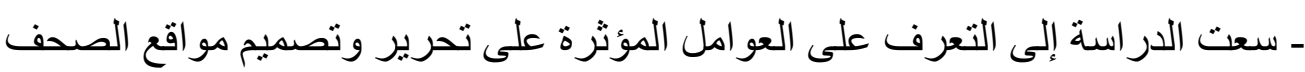

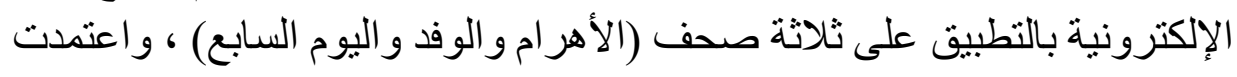

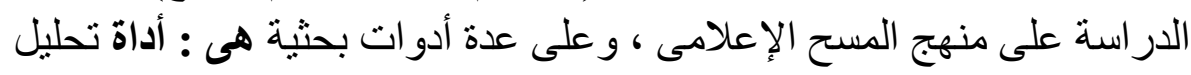

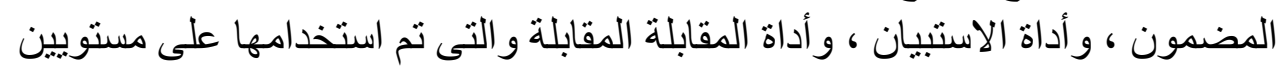

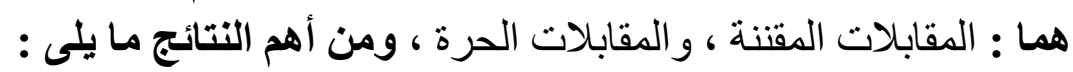

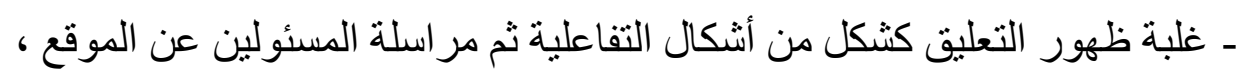

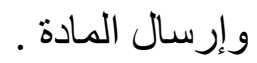
ـ استخدمت العناوين كوسيلة لإبر از الفقرات إضافة للألوان و الصور ، لـان الذا كثر استخدام

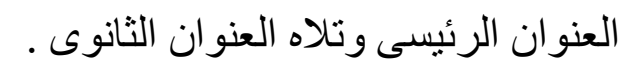

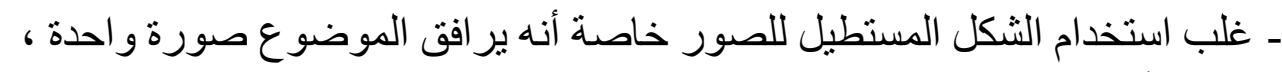

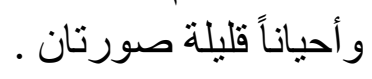

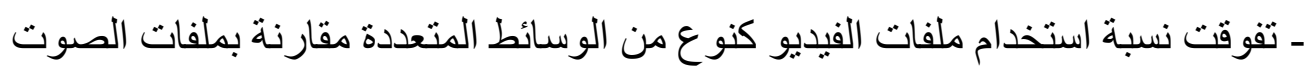

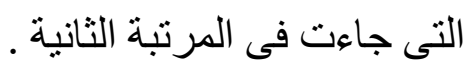


ع ـ دراسة (2010) Jonas Xavier Caballero ) حول مردود الانحياز الإعلامى

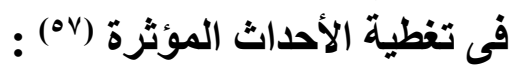

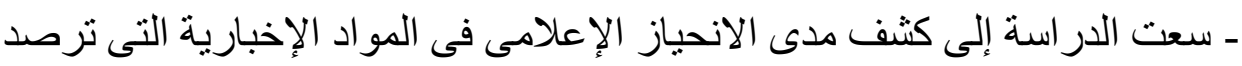

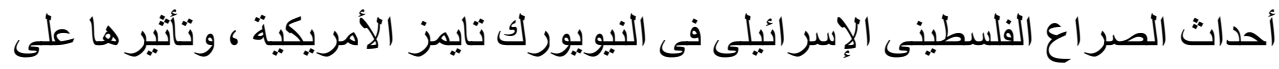

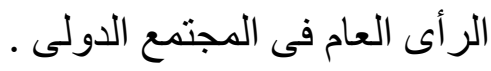

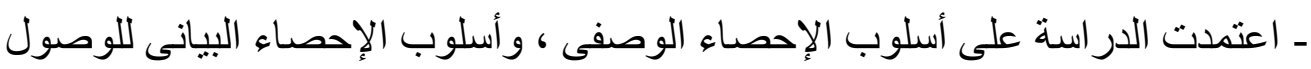

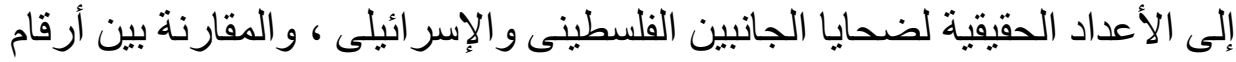
ونسب الضحايا ، وجاءت النتائج كالتالى :

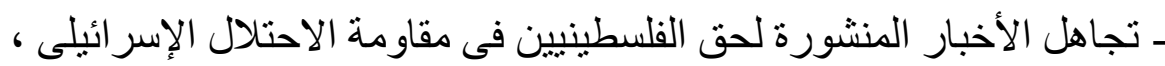

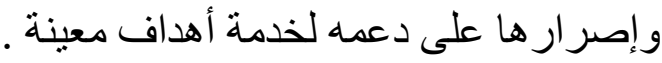

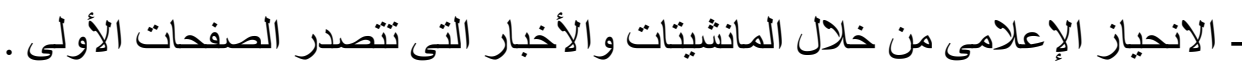

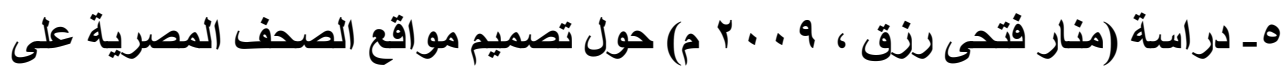
شبكة الإنترنت (^^)

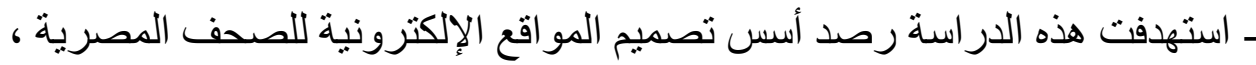

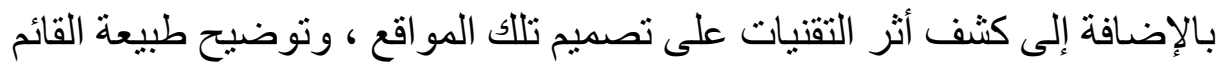

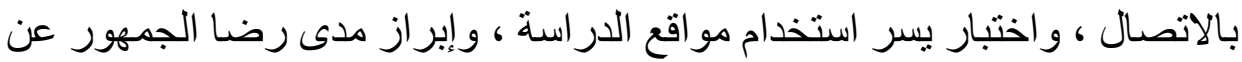
تللك المواقع ، وتوصلت الاراسة إلى النتائج التالية :

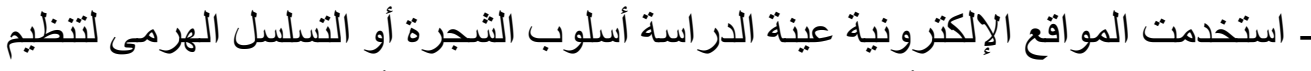

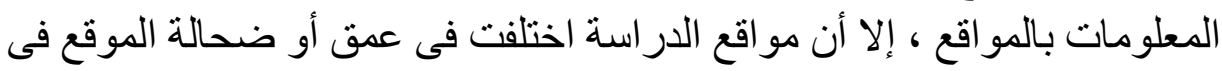
مقابل اتساعه أو ضيقه .

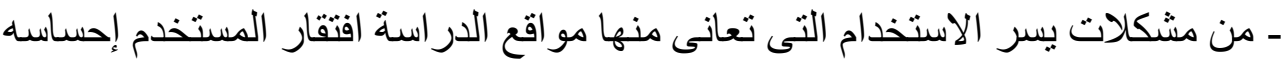

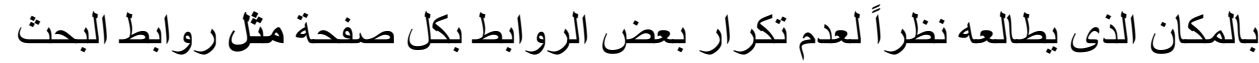

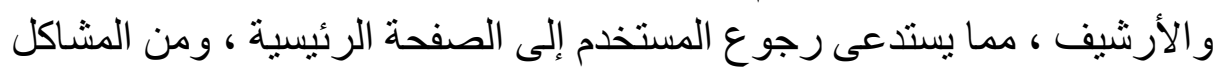

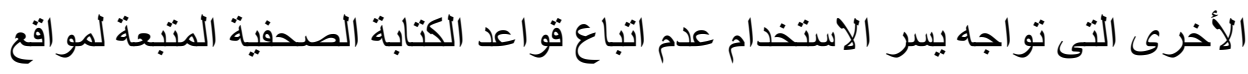

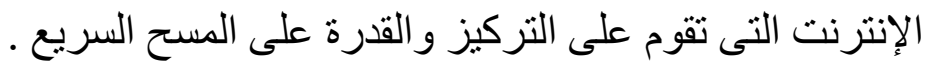

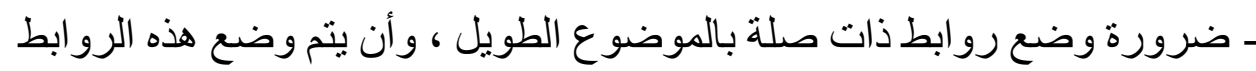

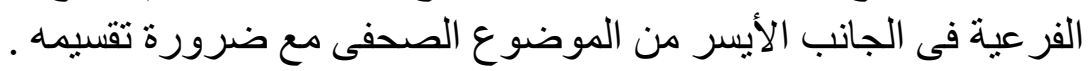

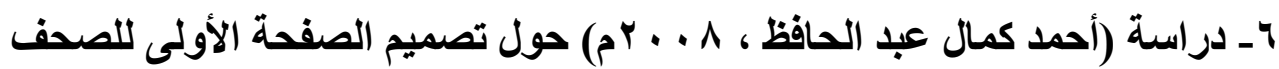

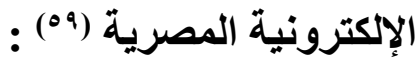

ـ استهافت هذه الدر اسة التعرف على تصميم الصفحات الأولى للصحف الإلكترونية الإنية

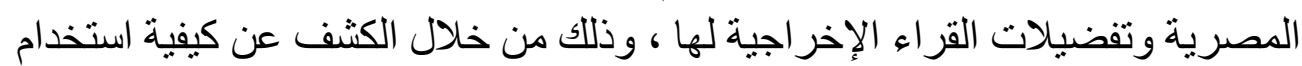

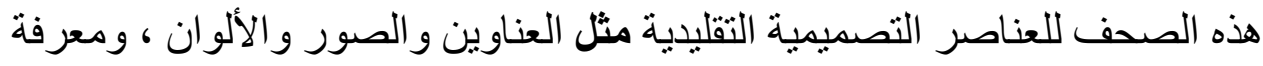

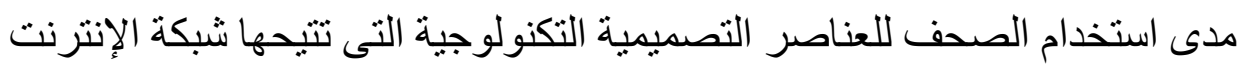

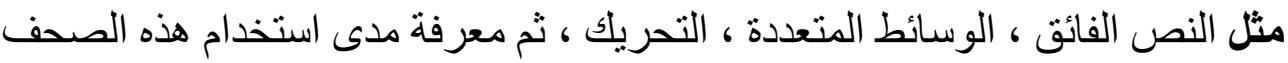
للعناصر التصميمية التفاعلية مثل (البريد الإلكترونى ـ الدردشة ــ المنتديات) . 


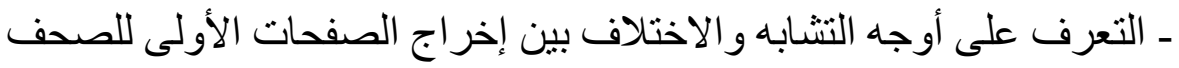

الإلكترونية المصرية ، وتوصلت الاراسة إلى العديد من النتائج من أهمها :

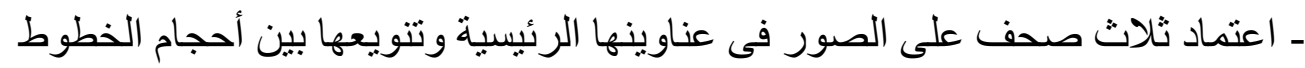
المستخدمة لكل من العناوين و التفاصيل .

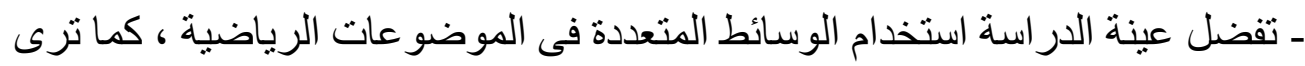

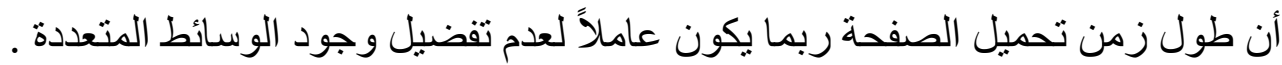

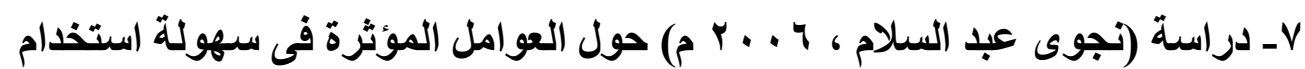

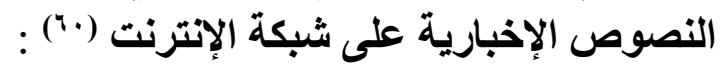

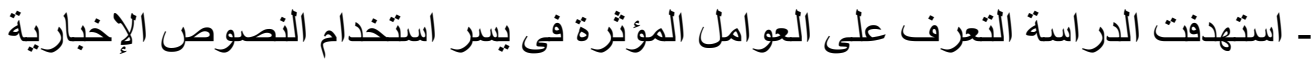

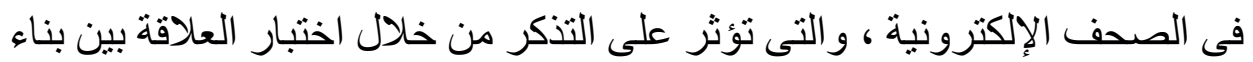

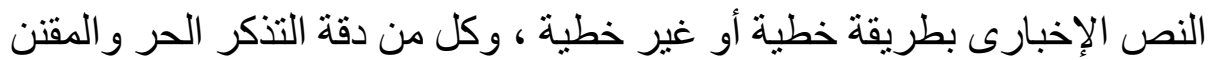
للمعلومات ، وتوصلت الاراسة إلى النتائج التالية :

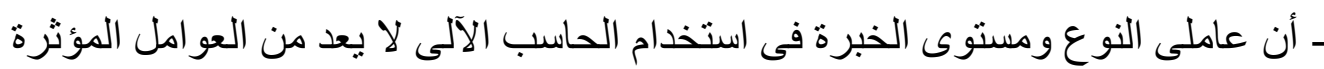

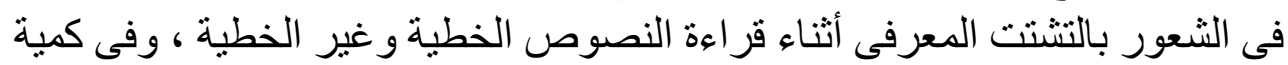

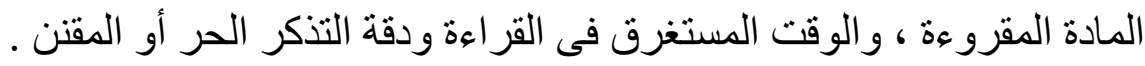

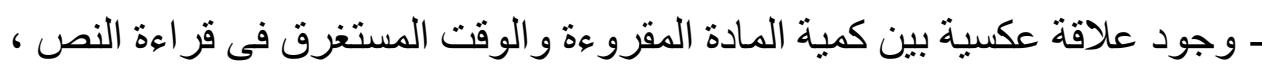

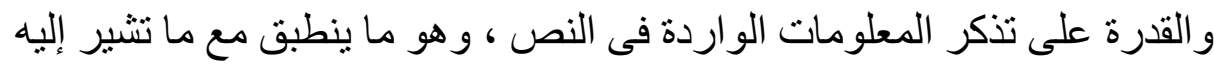

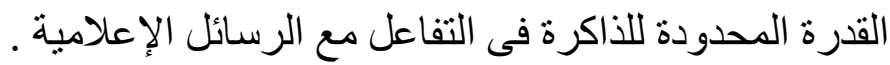

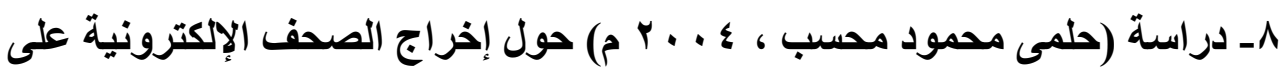

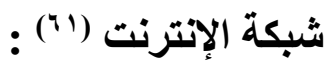

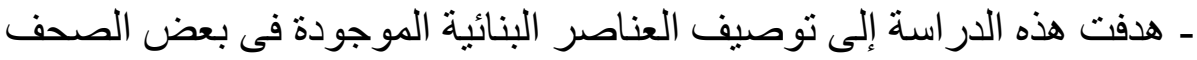

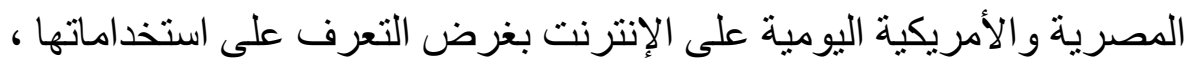

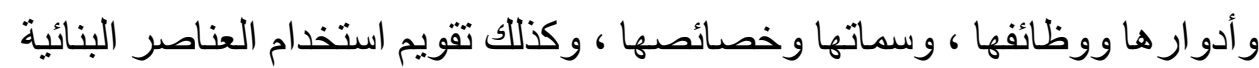
الموجودة فى الصحف المصرية والأمريكية ، وتوصلت وكائه الاراسة إلى النتائج التالية :

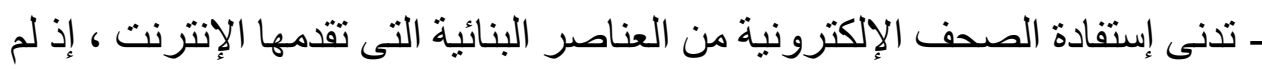

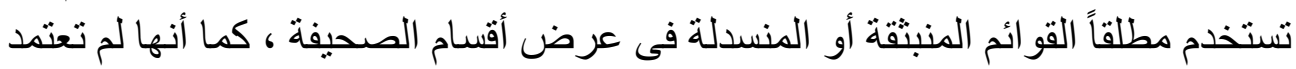

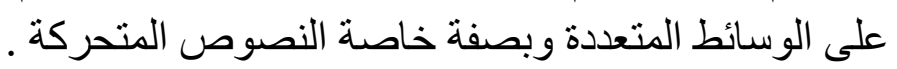

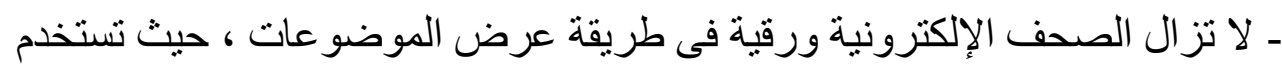

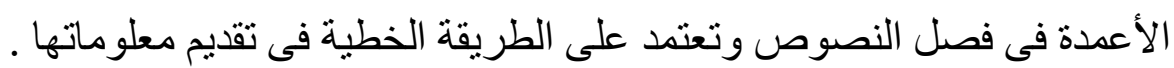

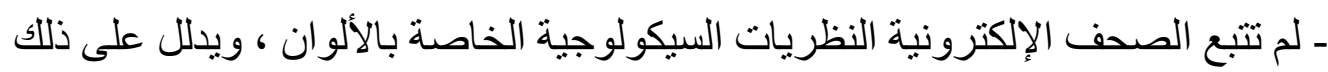

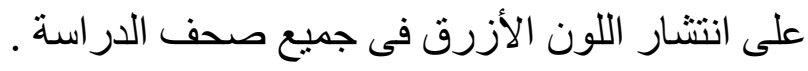

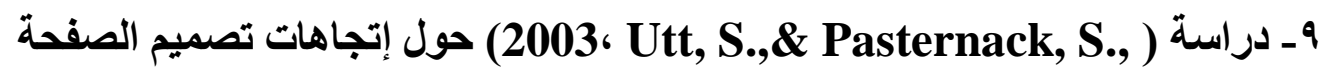

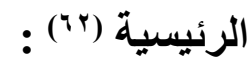

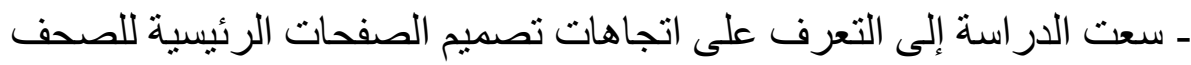
بنسختيها المطبو عة والإلكترونية على شبكة الإنترنت ، وذلاتك من خلال استخدامها 


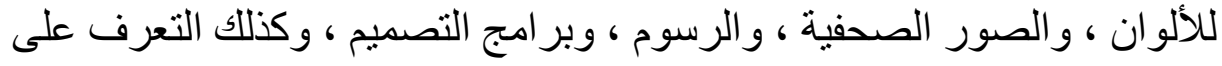

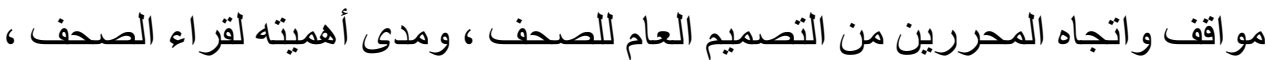

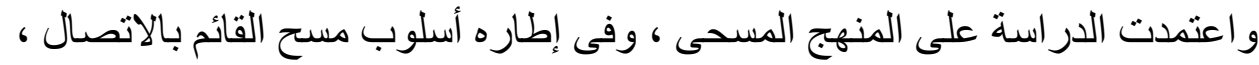
وتوصلت الدراسة إلى مجموعة من النتائج أهمها :

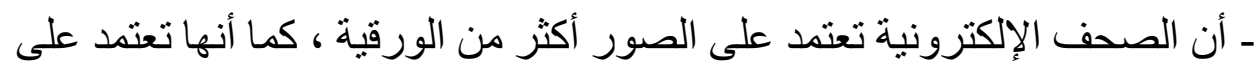

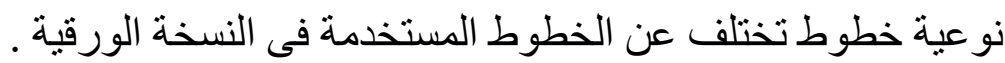
ـ أن حجم الخطوط والمنن فى النسخة الورقية يختلف عن تللك المستخدمة فى النسخة الإلكترونية ، وذلك لتلائم الخصائص النفسية للقارئ وتسهل عملية التصفح . ثامناً : نتائج الاراسة : توصلت الدراسة إلى التتائج التالية :

\section{حدول (1) يوضع طريقة معالجة المضامين الإخبارية على الصفحة الرئيسية}

\begin{tabular}{|c|c|c|c|c|c|c|}
\hline \multicolumn{2}{|c|}{ 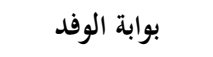 } & \multicolumn{2}{|c|}{ 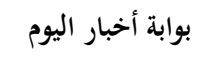 } & \multicolumn{2}{|c|}{ 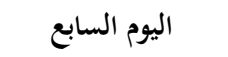 } & \multirow[t]{2}{*}{ 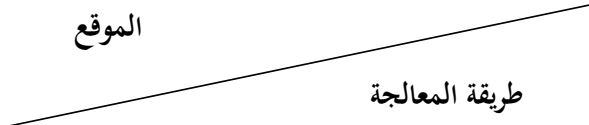 } \\
\hline$\%$ & 5) & $\%$ & ك) & $\%$ & s) & \\
\hline $0 \leqslant, 9$ & EMr|A & $\varepsilon r, \mu$ & $1 \wedge 1 \ldots$ & $\varepsilon \varepsilon, 7$ & Or $4 \leqslant Y$ & التركيز على أخبار معينة \\
\hline$\cdot r$ & ror & $\cdot, 1$ & ar & 0,4 & 9719 & صياغة الأخبار بطريقة مثيرة \\
\hline - & - & • & - & - & - & استخدام الثعارات المضللة \\
\hline Ir,Y & 9צห) & $17, \pi$ & 998. & $1 \cdot, \cdot$ & $11 v \leq 0$ & استخدام عمليات الدعاية السياسية للتأثير فى الجماهير \\
\hline - & - & - & - & - & - & استخدام الترغيب والتهديد لتضليل الرأى العام \\
\hline $1 \Lambda, r$ & $1 \leq \mu \varepsilon$. & $19, V$ & $\Lambda \leq \Psi \leq$ & $r M, \varepsilon$ & rVYon & انتقاء قصص إخبارية محددة والتركيز عليها \\
\hline $1 \varepsilon, \varepsilon$ & | & Y I,Y & arro & $17, \varepsilon$ & $194 v 9$ & التركيز على شخصيات معينة \\
\hline $1 \ldots$ & VAVฯ & $1 \ldots$ & \&rval & $1 \ldots$ & $11 \Lambda \cdot \varepsilon$. & المجموع \\
\hline
\end{tabular}

\section{ونستتتج من الجدول السابق :}

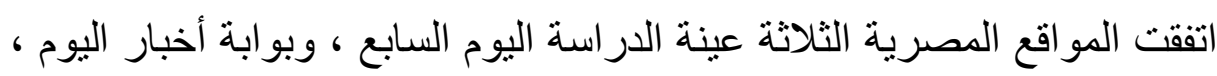

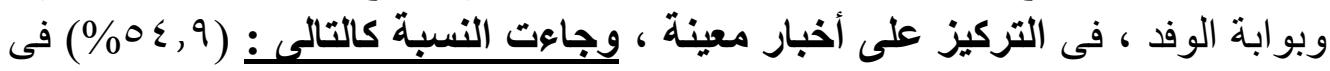

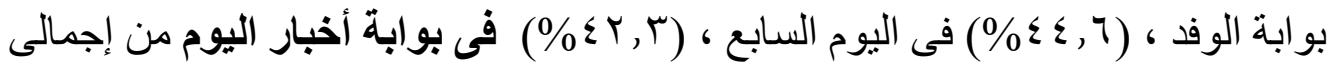

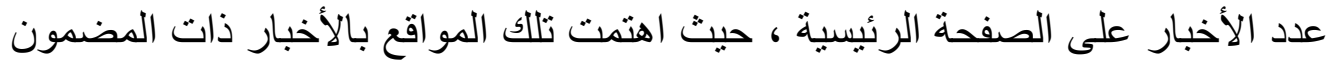

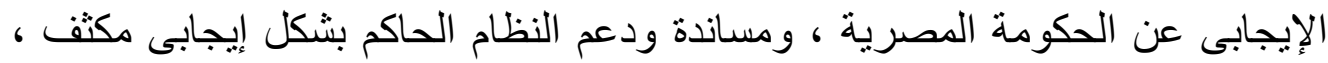

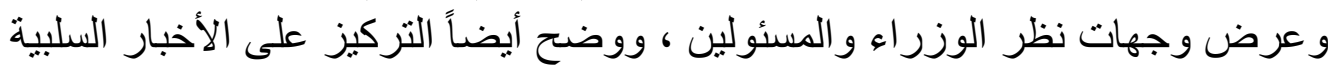

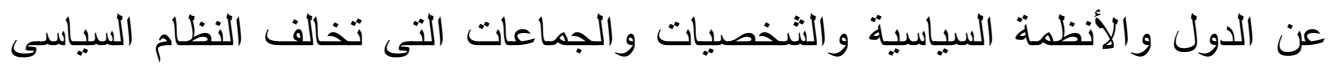

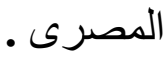

اتفقت المو اقع المصرية الثلاثة على صياغة بعض الأخبار بطريقة مثيرة ، وجاعت

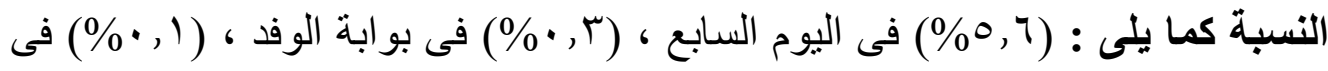

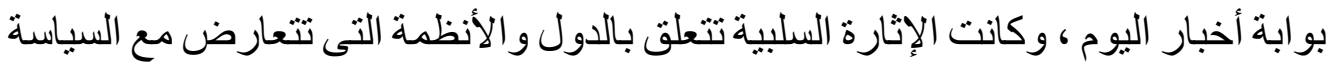

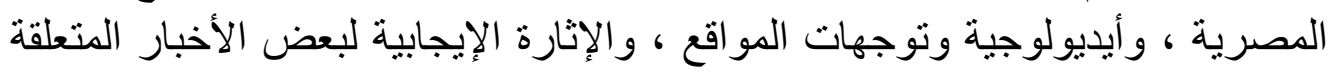
بإيجابيات النظام المصرى و وحكومته . 
اتفقت المواقع المصرية الثلاثة على عدم استخذام الثعارات المضلةة ، أو الترغيب والتهايد لتضليل الرأى العام .

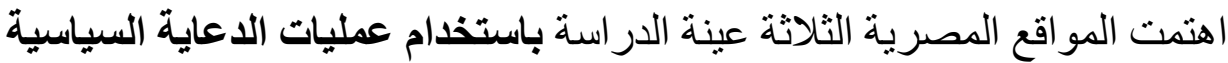

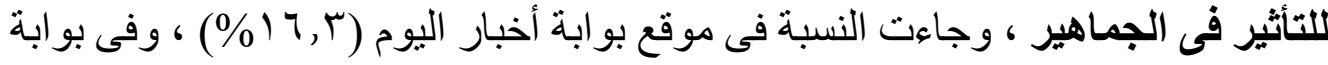

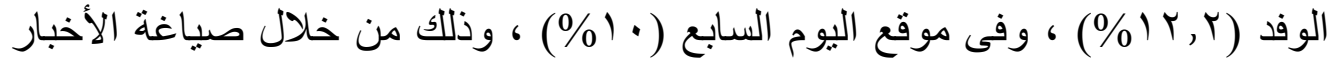

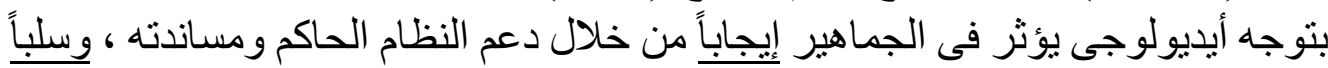

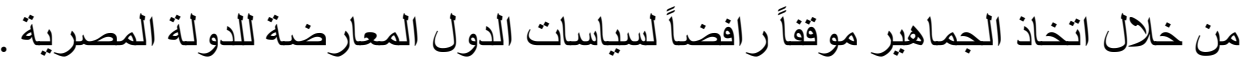

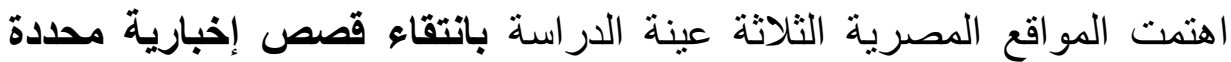

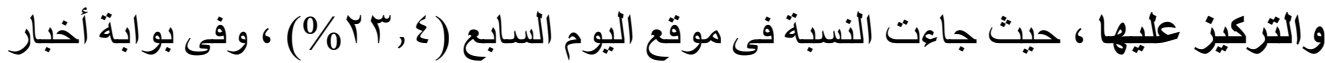

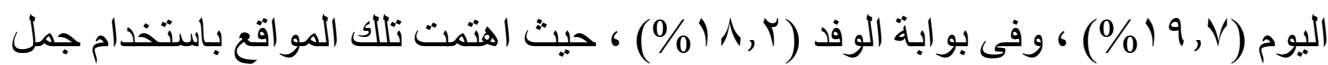

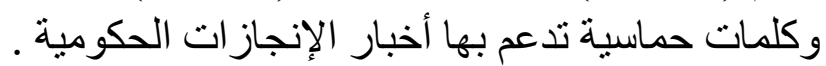

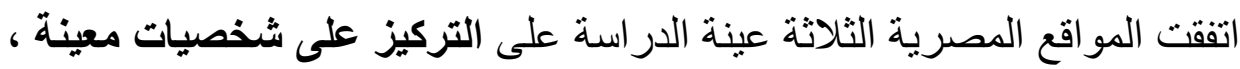

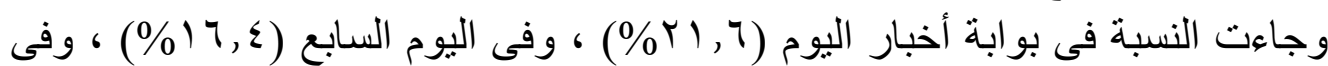

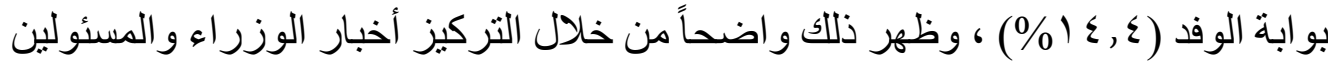

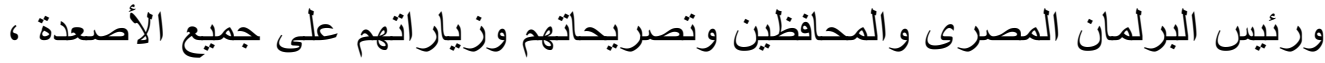
وكذلك التركيز على الأخبار السلبية على المستوى الدولى .

جلول (Y) يوضح زوايا معالجة الموضوعات على الصفحة الرئيسية

\begin{tabular}{|c|c|c|c|c|c|c|}
\hline \multicolumn{2}{|c|}{ 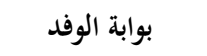 } & \multicolumn{2}{|c|}{ بوابة أخبار اليوم } & \multicolumn{2}{|c|}{ 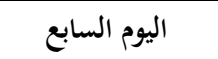 } & \multirow[t]{2}{*}{ 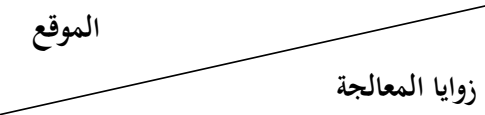 } \\
\hline$\%$ & ك & $\%$ & 5) & $\%$ & ك & \\
\hline १४, & $0 . M T V$ & 94,1 & rrvar & $9 \leqslant, \wedge$ & 9111 & عرض الموضوع دون تهويل أو تهوين \\
\hline$r, \varepsilon$ & IYYE & 7,7 & 1749 & $r, r$ & $r 1 \leqslant 4$ & تضخيم عناوين موضوعات معينة \\
\hline$\cdot, 0$ & ro. & $1, \Gamma$ & TY & 1,9 & IRTI & عرض الموضوع بسرد درامى مفتعل \\
\hline $1 \cdots$ & 01101 & $1 \cdots$ & $r \leqslant V \leqslant r$ & $1 \ldots$ & $90 \leqslant \wedge 1$ & المجموع \\
\hline
\end{tabular}

يتضح من الجدول السابق ما يلى :

اتفقت المواقع المصرية الثلاثة عينة الدراسة على عرض غالئلة البية الموضوعات

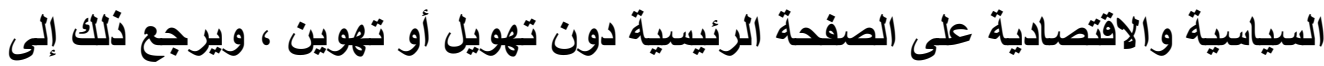

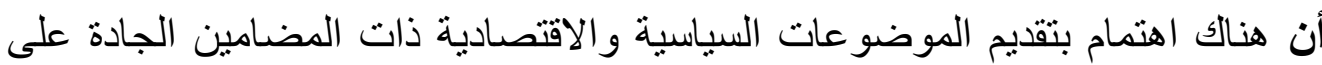

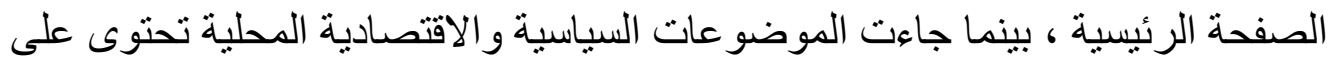

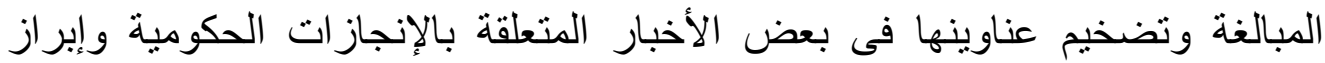

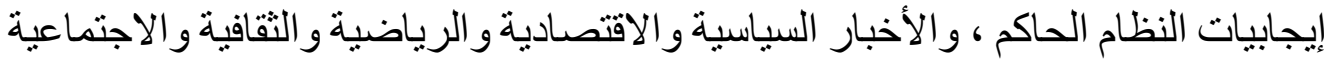

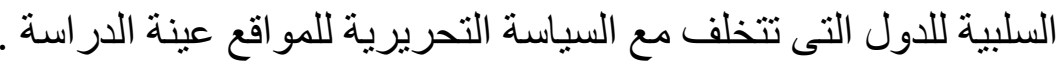

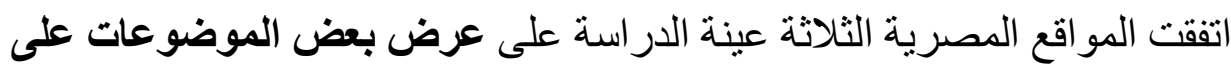

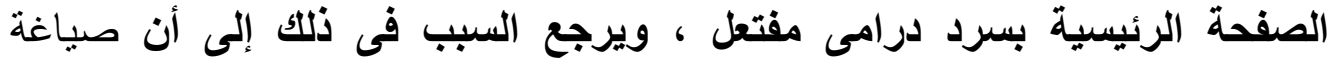

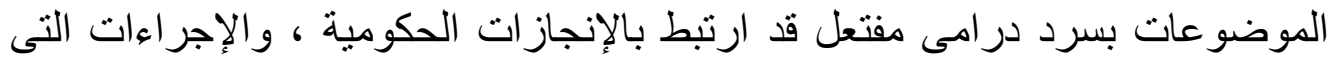

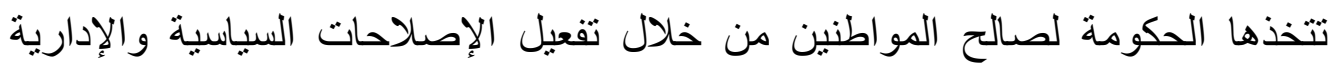
و الاقتصادية ، و التعامل مع المشكلات الإنسانية . 


\section{جلول (r) يوضح المعايير المهنية الأساسية فى التفطية الإخبارية}

\begin{tabular}{|c|c|c|c|c|c|c|}
\hline \multicolumn{2}{|c|}{ بوابة الوفد } & \multicolumn{2}{|c|}{ بوابة أخبار اليوم } & \multicolumn{2}{|c|}{ 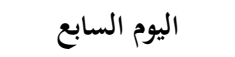 } & \multirow[t]{2}{*}{ الموقع } \\
\hline$\%$ & ك & $\%$ & 5) & $\%$ & 5) & \\
\hline 19,1 & $\varepsilon r v q 0$ & r I,V & $r .19 r$ & 10,7 & $00 q \cdot V$ & المصداقية \\
\hline Yl, & \&4rV| & $17, r$ & lorr. & $I V, r$ & $71 \leq 1 Y$ & الشمولية \\
\hline 19, & \&19v9 & $\mathrm{i} \Lambda, \mathrm{V}$ & $\mid V \leq 11$ & 10,0 & צ. . & الموضوعية \\
\hline$\cdot, 0$ & 1.77 & $\cdot, \Lambda$ & VYA & •,$r$ & 919 & التوازن \\
\hline 1,0 & $r \varepsilon \cdot r$ & 1,9 & $1 v 9$. & $\cdot, r$ & Err & التعددية فى الرأى والرأى الآخر \\
\hline $19,$. & \&Yा & $r, 0$ & 19170 & 17,7 & $0 q \leq r V$ & الدقة \\
\hline - & - & - & - & $1 V, 7$ & גוזד & التفاعلية \\
\hline $19, Y$ & Err & $r \cdot, l$ & $\mid \wedge V \leq 1$ & IV, & TYIKA & النزاهة \\
\hline $1 \ldots$ & YY. TV & $1 \ldots$ & qMYTo & $1 \ldots$ & rovvy & المجموع \\
\hline
\end{tabular}

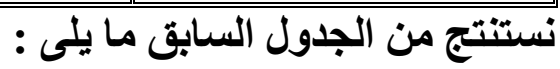

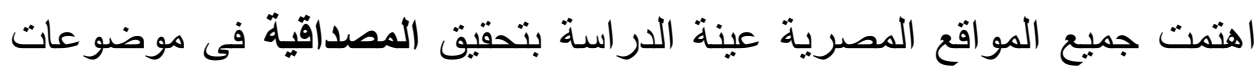
الصفحة الرئيسية ، واعتمدت على محاولة تحقيق المصداقية فى النشر منذ لحظة الحصول

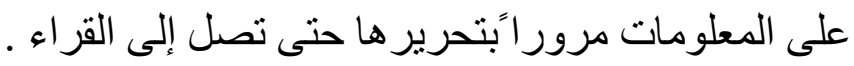

اهتمام جميع المواقع المصرية بتحقيق الشمولية فى موضو عات الصفحة الرئيسية ، وقد لوحظ ذللك من خلال التغطية الثاملة للأحداث على الصعيدين المحلى و الدولى ،

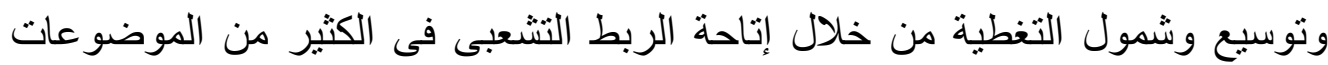
السياسية للوصول إلى معلومات أكثر بالنسبة للزائر .

اهتمام جميع المواقع المصرية بمحاولة تحقيق الموضوعية فى الموضو عات

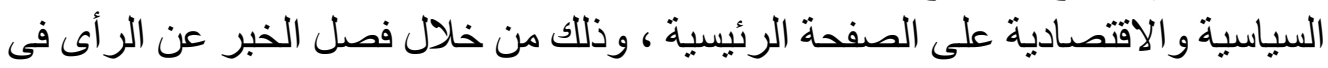

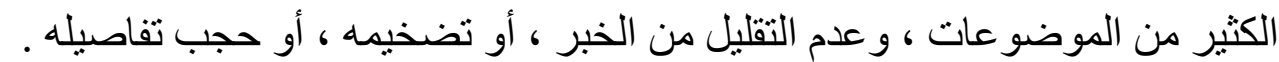

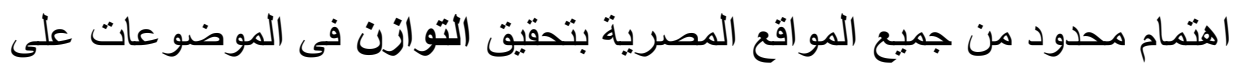

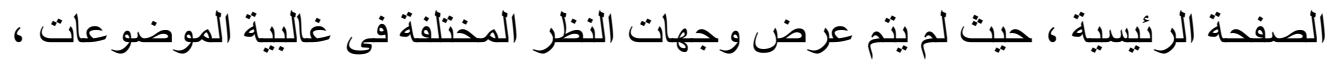
و انما عرض وجهات نظر محدودة ، و التغاضى عن وجهات النظر الأخرى وتهميثها ، وذلك على الر غم من أهميته فى إضفاء المصداقية على القصة الإخبارية .

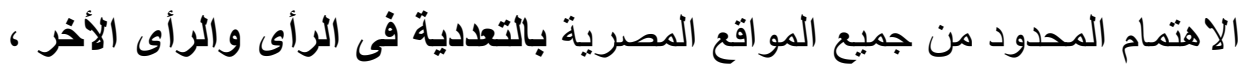

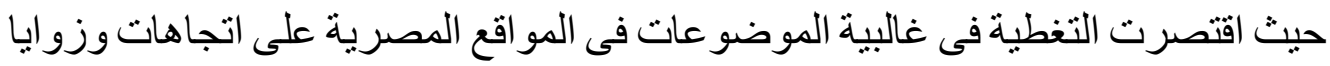
معينة من الأحداث ، وتجاهل أخرى ، وذلك بما يتو افق مع أيديولوجية وتوجهات هذه

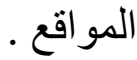

اهتمام جميع المواقع المصرية بتحقيق الدقة فى غالبية الموضو عات على الصفحة

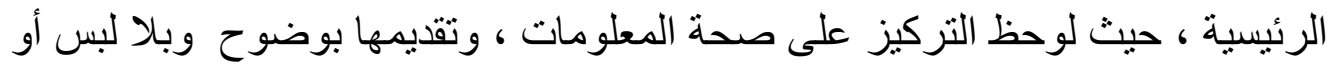

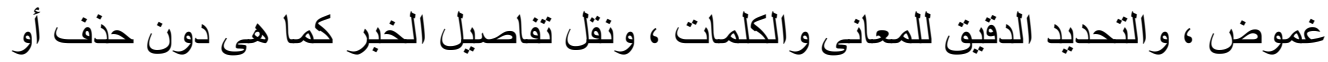




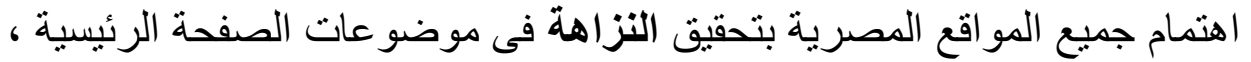

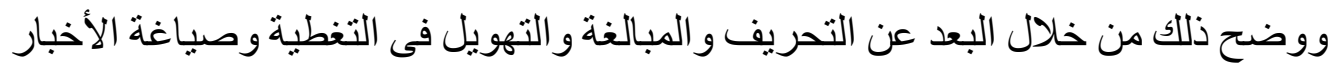

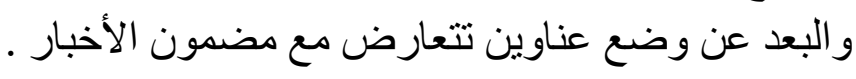

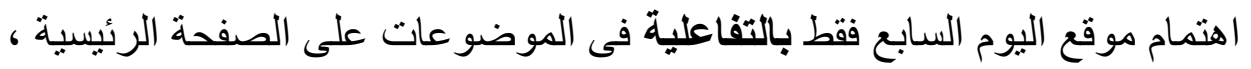

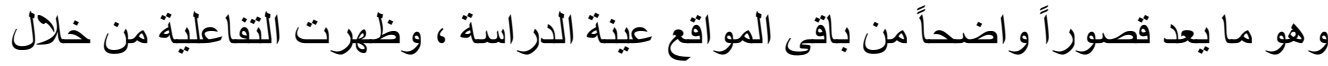

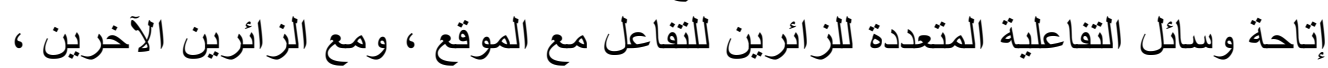
وذللك من خلال التعليقات ، و التعليق على التعليق . لتانئ

جدول (؟) يوضح اتجاه مضمون التغطية الإخبارية ولية

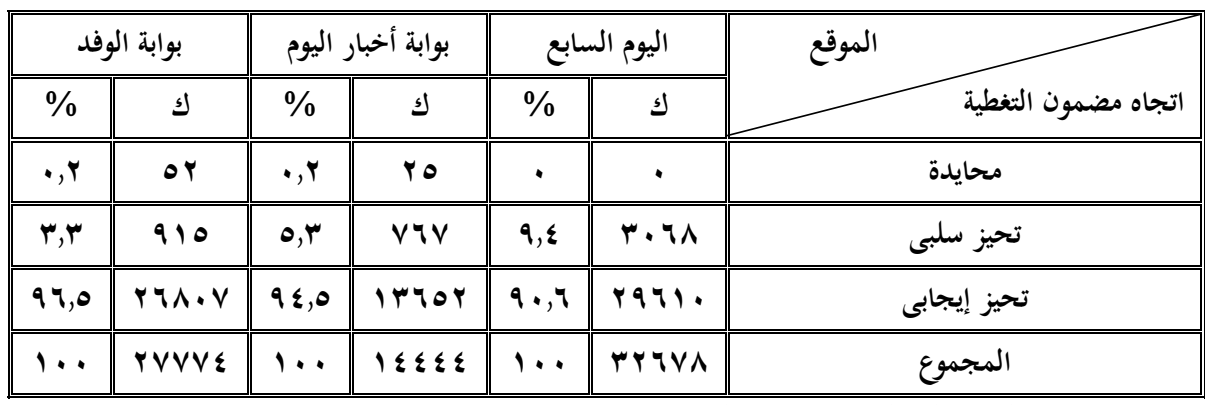

نستنتج من الجدول السابق ما يلى :

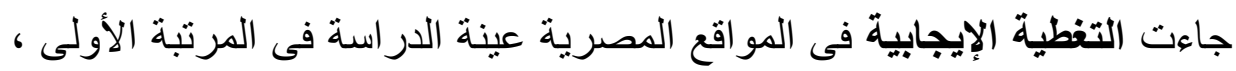

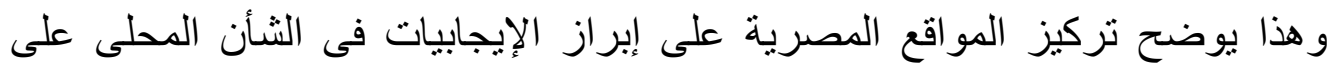

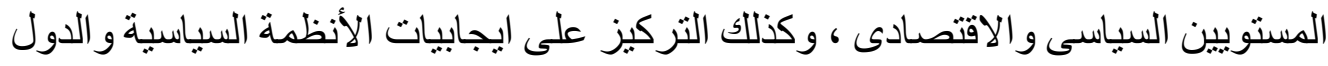

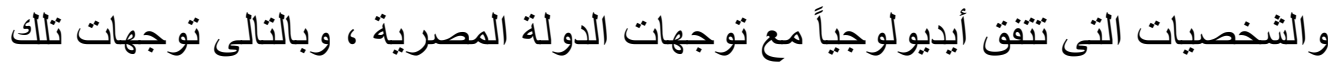

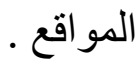

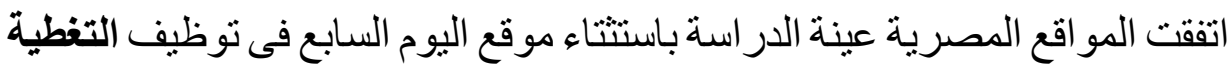

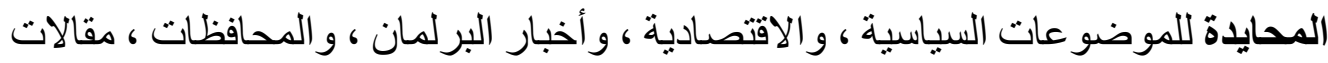

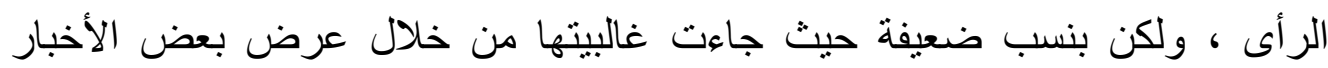

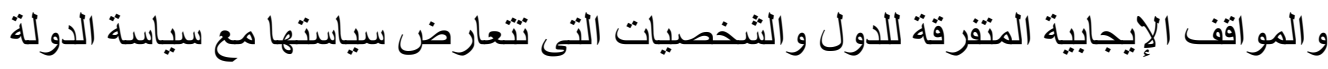

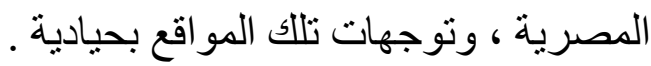

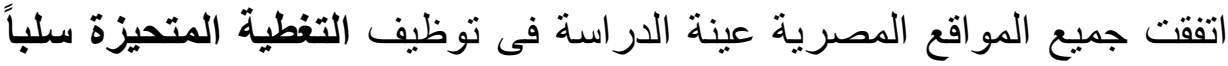

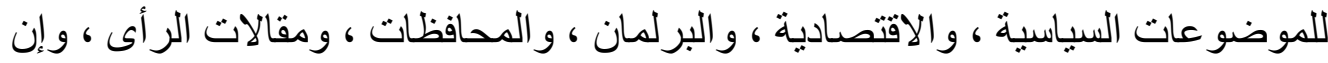

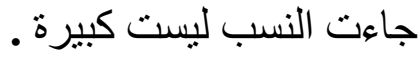


حذول (0) يوضح أثكال وآليات التحيز في موضوعات الصفحة الرئيسية

\begin{tabular}{|c|c|c|c|c|c|c|}
\hline \multicolumn{2}{|c|}{ 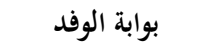 } & \multicolumn{2}{|c|}{ بوابة أخبار اليوم اليوم } & \multicolumn{2}{|c|}{ 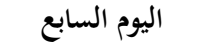 } & \multirow[t]{2}{*}{ 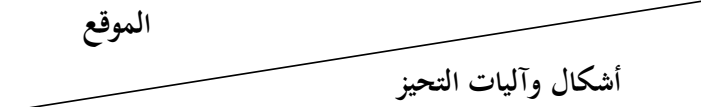 } \\
\hline$\%$ & ك) & $\%$ & ك) & $\%$ & 5) & \\
\hline $1, \bullet$ & 019 & $Y, Y$ & 111 & $r, \cdot$ & $1 \%$ & التركيز على الجوانب السلبية لجهة معينة وإبرازها \\
\hline - & - & - & - & - & • & الاهتمام بالقصص ذات الصور الأفضل \\
\hline$\cdot 1$ & or & $1, \Lambda$ & V99 & $\cdot 9$ & $0 \wedge 9$ & التركيز على القصص ذات الحبكة الدرامية \\
\hline$\vee, \Lambda$ & $\varepsilon \cdot \varepsilon \varepsilon$ & $r \wedge, r$ & 19.97 & $11, r$ & $\vee \varepsilon \ldots$ & الميل لطرف أو أكثر على حساب طرف أو أطراف أخرى \\
\hline - & . & - & - & - & • & حذف أو تغييب الحقائق التى تؤكد وجهة نظر معينة \\
\hline$\cdot 1$ & 01 & $\cdot, 0$ & Y & $\cdot 1$ & 70 & وضع قصة فى صدر الصفحة الرئيسية على مساحة كبيرة رغم عدم \\
\hline 7,8 & Priq & $r \leqslant, \Lambda$ & $1 \cdot 7 \ldots$ & $\vee, V$ & $0 . \leqslant \mu$ & حشد أكبر عدد من المصادر لتأييد وجهة نظر معينة \\
\hline $79, \cdot$ & rovV & $r V, \varepsilon$ & IVIr & $\Delta V, \varepsilon$ & rv॰q. & استحسان أو استهجان سياسة ما فى صياغة القصة \\
\hline $10, \varepsilon$ & 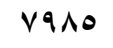 & Ir,o & ovV. & $r \cdot, l$ & r & تقديم الرأى على أنه حقيقة لخدمة وجهة نظر معينة \\
\hline - & - & - & - & - & - & عدم تقديم خلفية القصة مما يؤدى إلى تحريف معناها \\
\hline - & - & - & - & $\cdot, r$ & 14 & تناول حقائق مشوهة لخدمة وجهة نظر معينة \\
\hline - & - & - & - & - & - & عدم توافق عنوان القصة مع المضمون لخدمة وجهة نظر معينة \\
\hline$\cdot 1$ & or & $\cdot, \mathrm{V}$ & ५१৭ & $\cdot, r$ & Irr & عرض الخبر وإبرازه بصورة تزيد عن قيمته الإعلامية \\
\hline$\cdot 1$ & 01 & $\bullet, \varepsilon$ & $|v|$ & $\cdot 1$ & 70 & الاهتمام بأحداث وتصريحات وزيارات للمسئولين لا تهم الجمهور \\
\hline $1 \cdots$ & 01101 & $1 \cdots$ & $r \leq V \leq r$ & $1 \cdots$ & $\Upsilon 0 \leqslant \wedge \wedge$ & 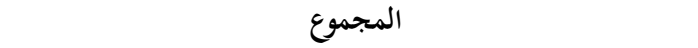 \\
\hline
\end{tabular}

نستتتج من الجدول السابق ما يلى :

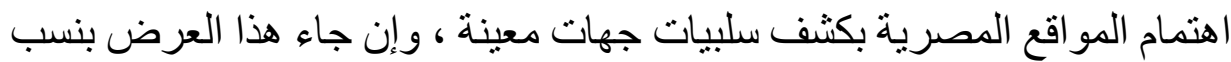
ضعيفة ، وبما يتفق مع أيديولوجية المو اقع المصرية بعدم تكثيف الموضو عات التى تتضمن

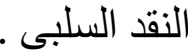

اهتمت المو اقع المصرية باستحسان سياسات معينة فى صياغة القصص ، و و وتقيميم

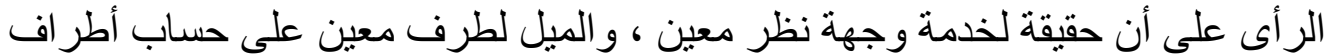

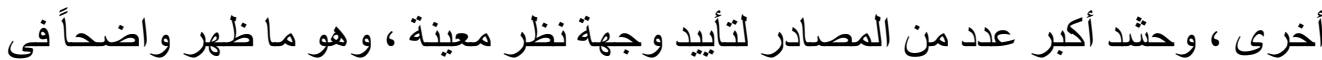

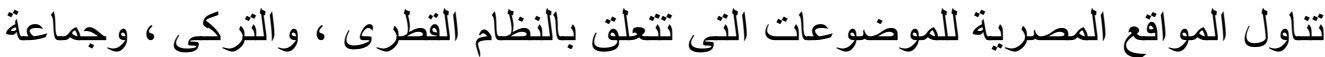

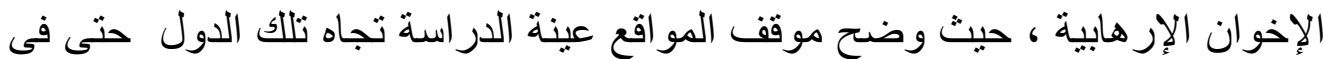

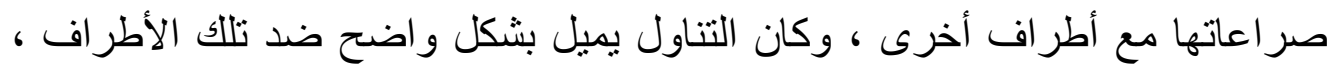

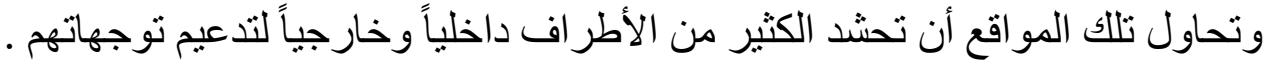
اهتمت المو اقع المصرية فى بعض الموضوعات بالتركيز على زيار ات للمسئولين لا تهم الجمهور بشىء ، وعرض الخبر التبر إبر ازه بصورة تزيد عن قيمته الإعلامية . 
حلول(7) يوضح معايير استخدام المصادر المجهلة في موضوعات الصفحة الرئيسية

\begin{tabular}{|c|c|c|c|c|c|c|}
\hline \multicolumn{2}{|c|}{ بوابة الوفد } & \multicolumn{2}{|c|}{ بوابة أخبار اليوم } & \multicolumn{2}{|c|}{ 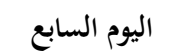 } & الموقع - م المع \\
\hline$\%$ & ك & $\%$ & ك & $\%$ & ك & معايير استخدام المصادر المجهلة \\
\hline צ & 171 & r४,O & $\leq r$ & $r, q, q$ & mio & استخدم لسبب واضح ومبرر \\
\hline$r V, \varepsilon$ & 174 & Q & 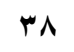 & $r V, r$ & $\varepsilon \Gamma \varepsilon$ & الخيار الوحيد المتاح لنشر الخبر \\
\hline . & . & - & . & - & - & سبب التجهيل مذكور فى صلب الخبر \\
\hline YY,A & Irs & $r 0, r$ & «1 & $r \leqslant, q$ & एव & المعلومات مهمة للجمهور أو الرأى العام \\
\hline$r, r, r$ & $1 \leqslant 1$ & $r \leqslant, V$ & $\leq$. & $r \leqslant, q$ & raq & فوائد استخدامه أكبر من عدم استخدامه \\
\hline $1 \ldots$ & 7.7 & $1 \ldots$ & 174 & $1 \ldots$ & 1091 & المجموع \\
\hline
\end{tabular}

ونستتنج من الجدول السابق أن :

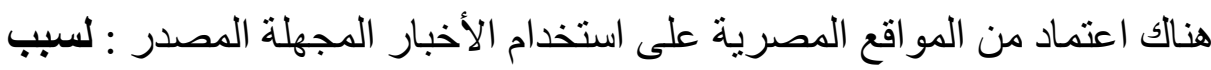

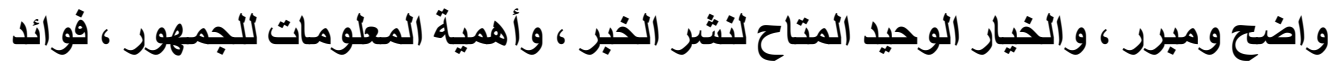
استخدام الأخبار المجهلة أكبر من عدم استخدامها ، وذللك بنسب متقاربة ومهمة للتغطية

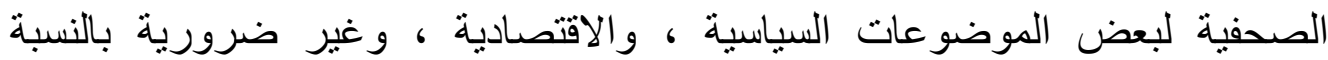

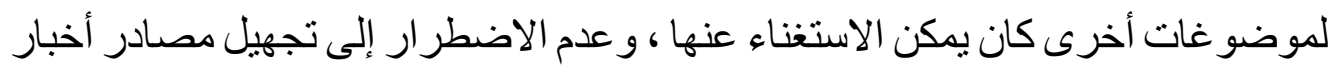

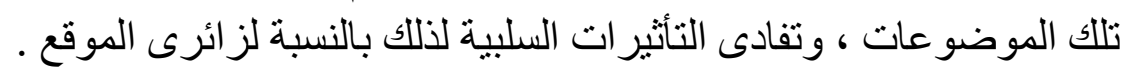

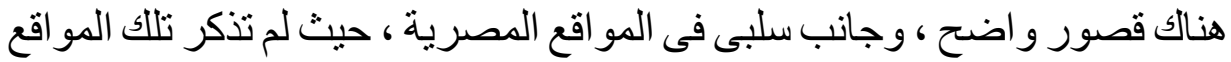

نهائباً سبب اللجؤ إلى تجهيل غالبية المصادر على الصفحة الرئيسية .

\section{الأيديولوجيا والأبعاد التفاعلية والمشاركة}

المشاركة والمتابعة على مواقع التواصل الاجتماعى

اتفقت جميع المو اقع المصرية فى الاهتمام بالمشاركة والمتابعة على مواقع

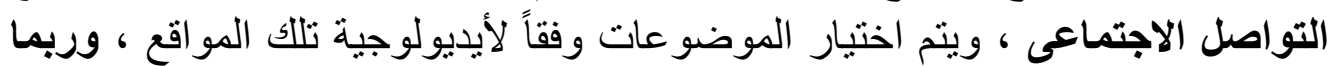

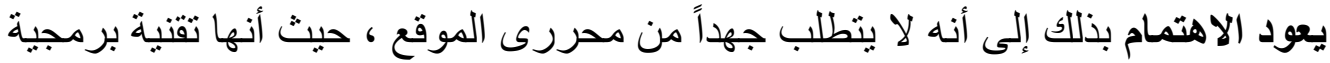

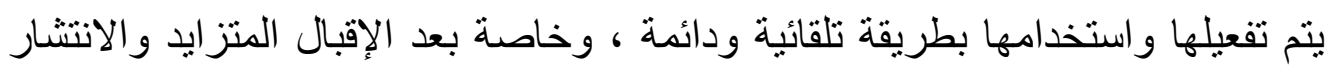

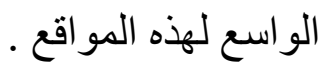
صحافة المواطن : مون جاء الاهتمام بصحافة المواطن ضعيفاً فى المو اقع المصرية ، وذللك على الرغم

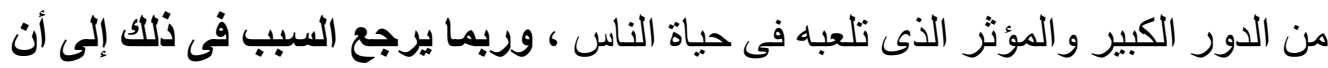

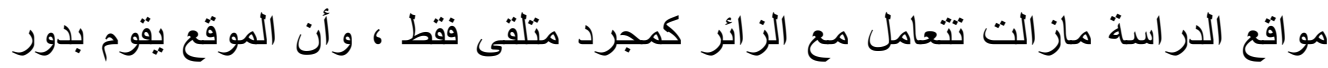

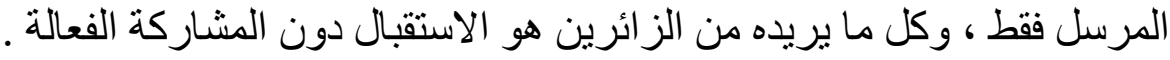

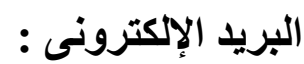

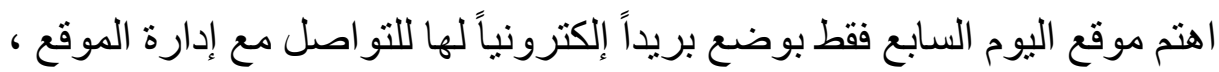

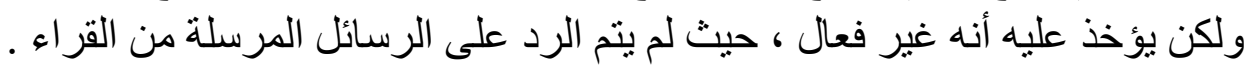




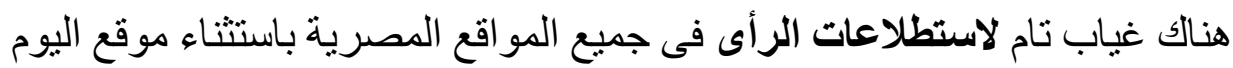

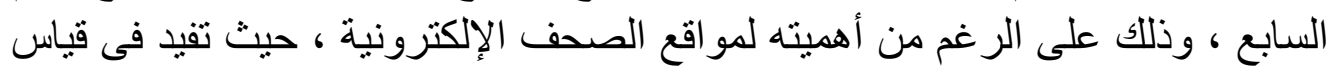

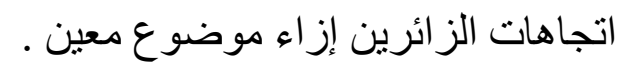

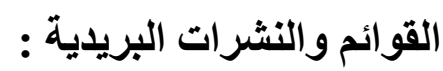

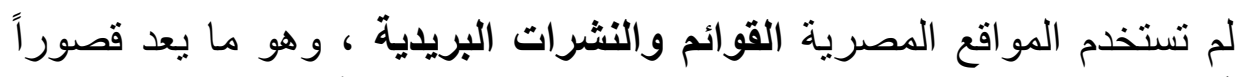

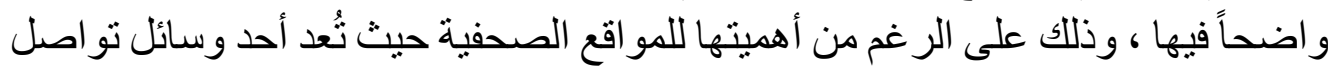

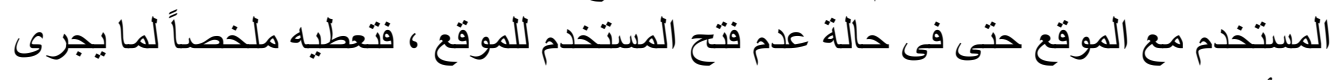

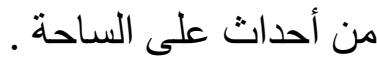

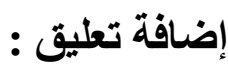

اتفقت جميع المواقع المصرية فى توظيف إمكانية إضافة التعليقات ، وذللك إدر اكاً

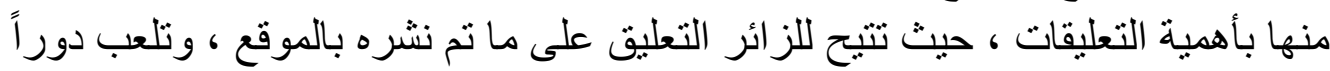

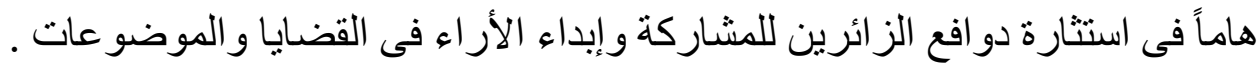
تقييم أعجبنى - لم يعجبنى :

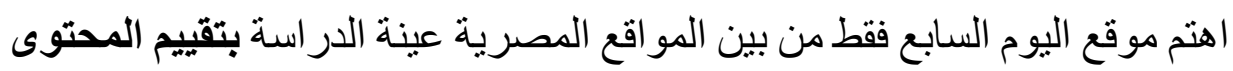

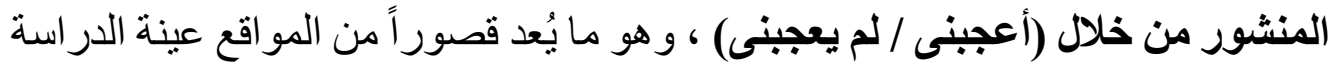

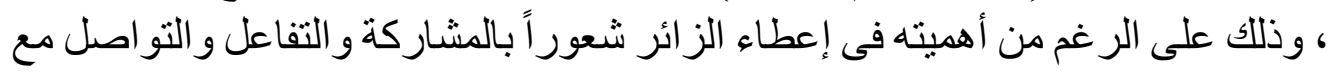

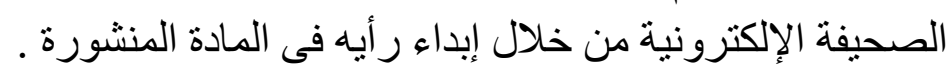

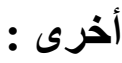

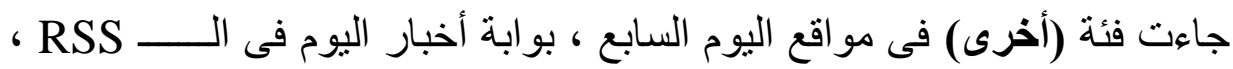

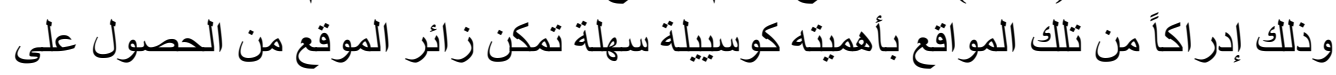

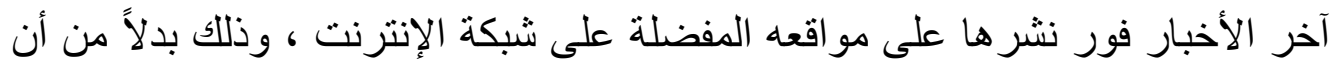

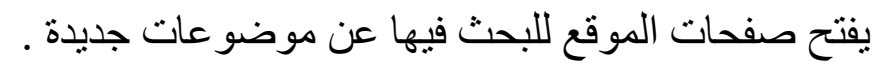

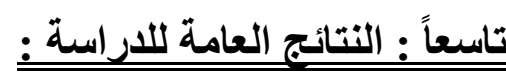

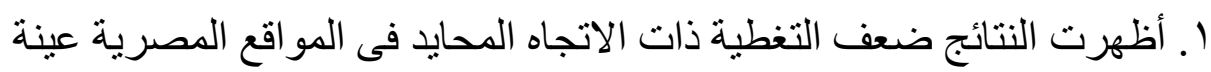

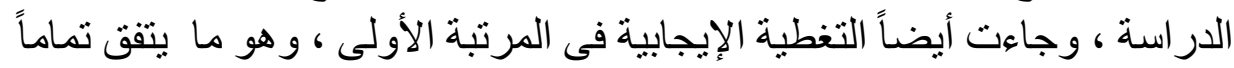

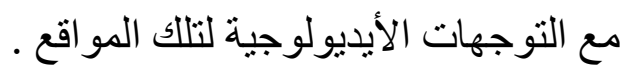

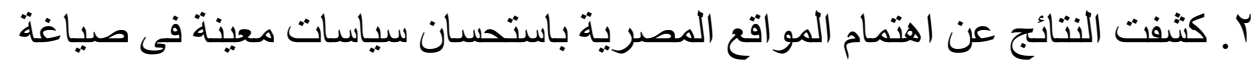

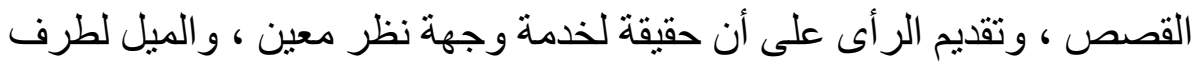

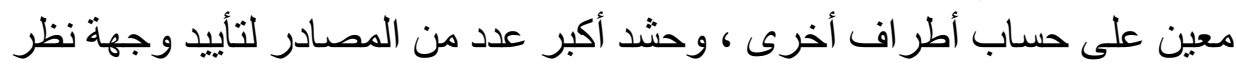

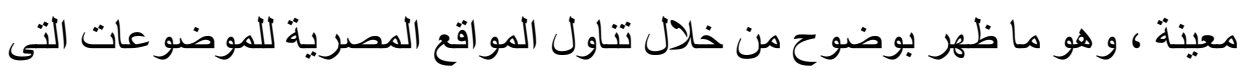

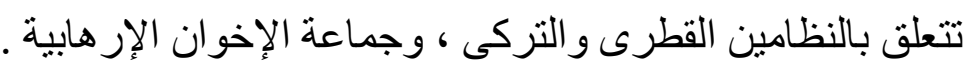

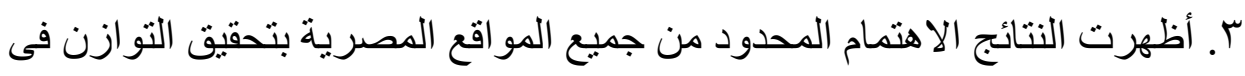

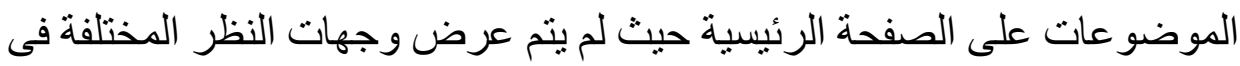




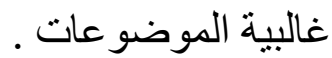

ع. كثفت النتائج اهتمام جميع المو اقع المصرية بتحقيق المصداقية ، الثمولية ، والية

$$
\text { الموضو عية فى غالبية الموضو عات على الصفئ الصفحة الرئيسية . }
$$

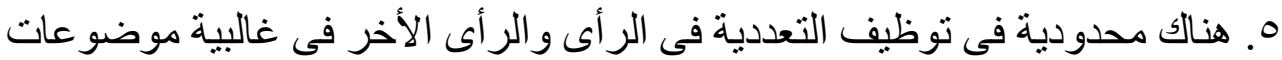
الصفحة الرئيسية حيث اقتصرت التغطية على اتجاهات وزو ايا معينة من الأحداث و تجاهل أخرى ، وذلك بما يتو افق مع أيديولوجية وتوجهات هذه المو اقع .

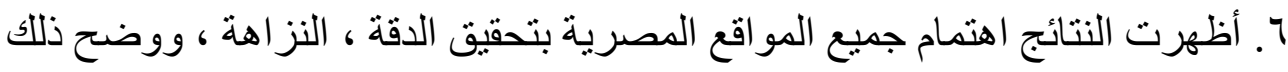

من خلال البعد عن التحريف والمبالغة والتهويل فى التغطية وصياغة الأخبار .

V. كثفت النتائج عدم اهتمام المو اقع المصرية بالتفاعلية باسنثناء موقع اليوم السابع ،

$$
\text { وهو ما يعد قصور او اضحا فى تللك المو اقع . }
$$

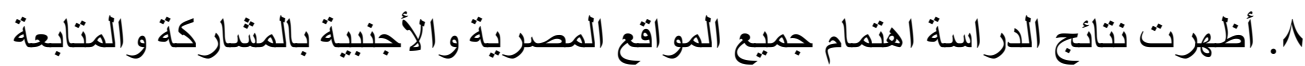

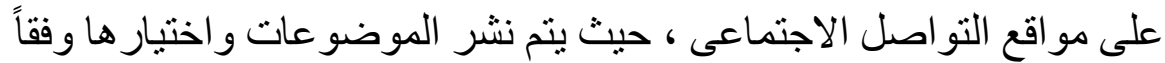

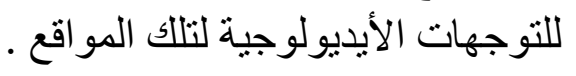

9 ـ كثفت نتائج الدر اسة عن ضعف الا هتمام بصحافة المو اطن فى المو اقع المصرية ،

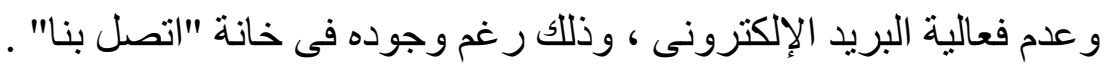

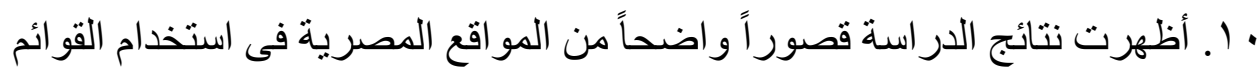

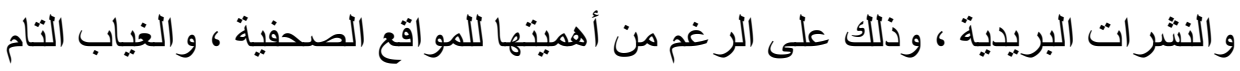

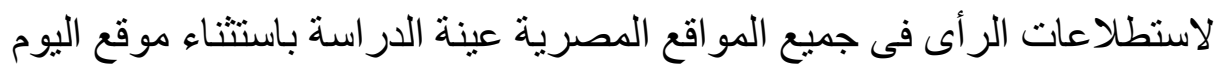
المابع

11 ـ كثفت نتائج الدر اسة عن قصور و اضح من المواقع المصرية فيما يتعلق بتقييم

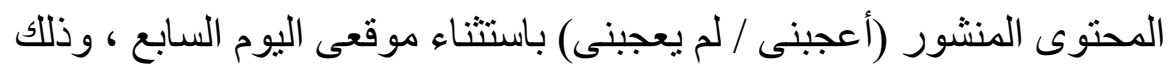

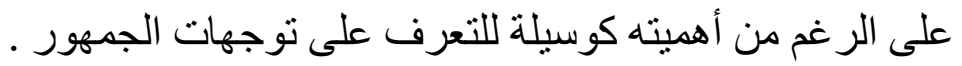




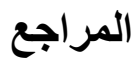

( (1) معين صالح الميتمى ، تفضيلات مستخدمي الإنترنت لتصميم المو اقع الإخبارية

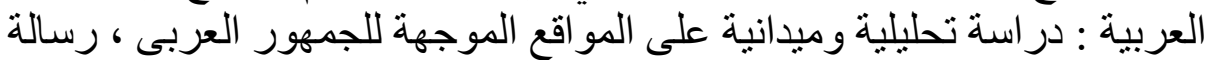

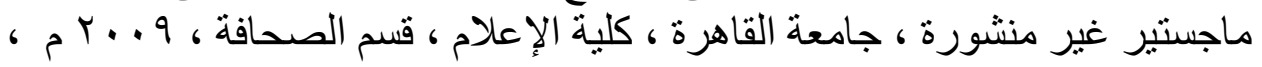

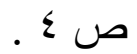

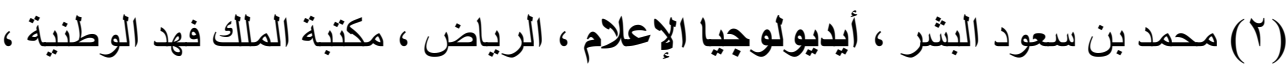

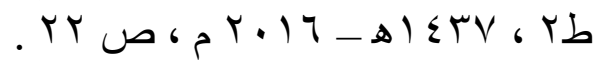

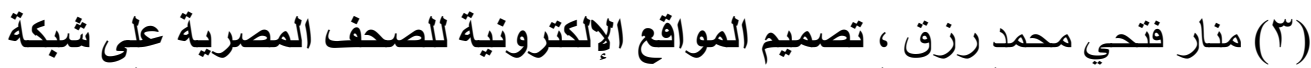

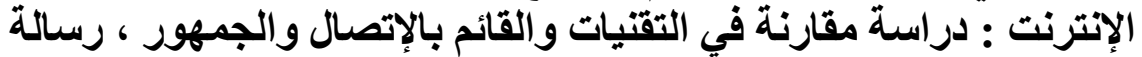

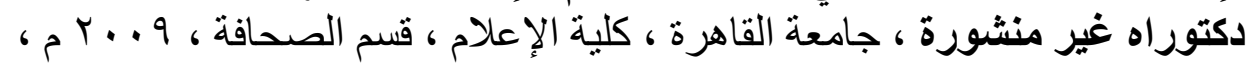

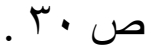

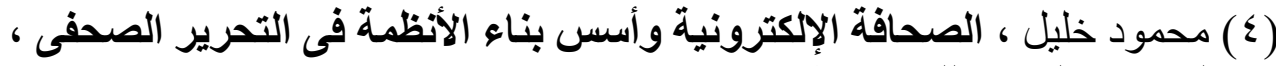

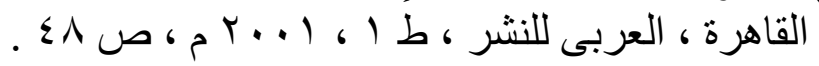

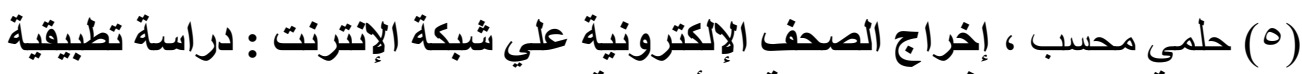

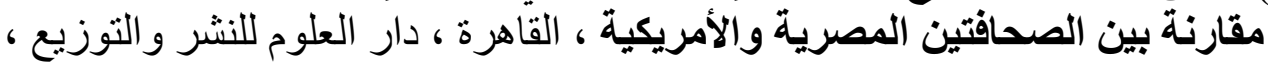

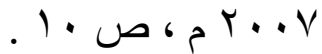

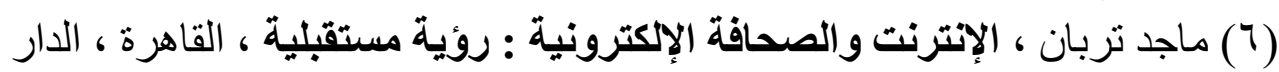

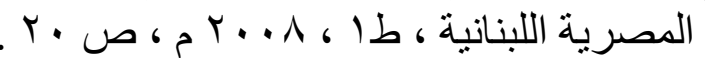

(7) Lilleker, Darrn D., Key Conepts in Political Communication, London: Sage Publication, 2006.

(8) Ibid. p.92.

(9) Gouldner, Alvin W., The communications revolution: News, public, and ideology, In: Denis McQuail,s edition: McQuails Reader in Mass communication Theory. London: Sage, 2004, p.87.

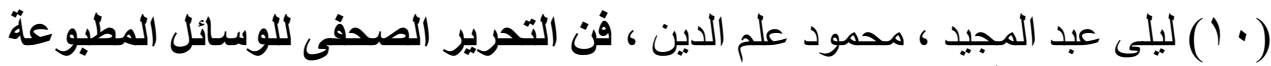

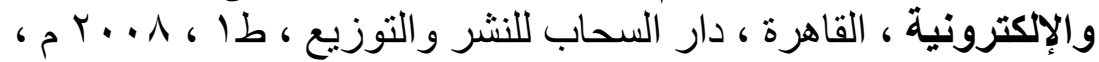

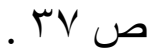

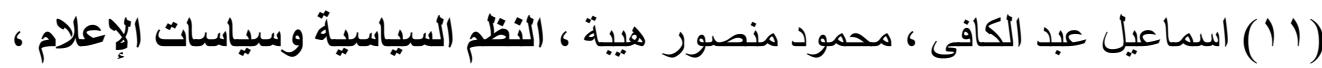

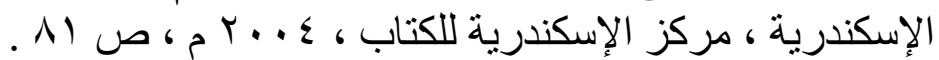

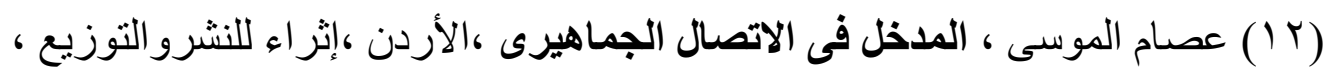

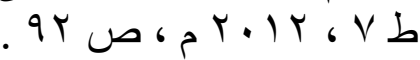

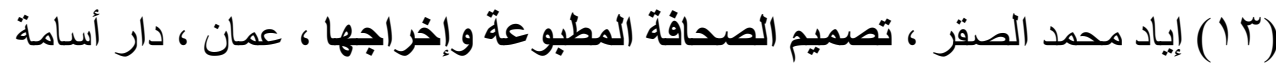

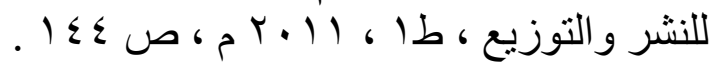

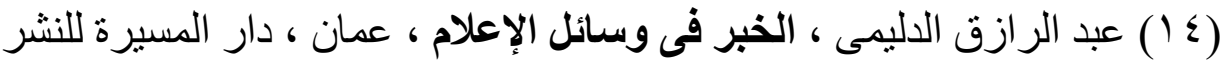

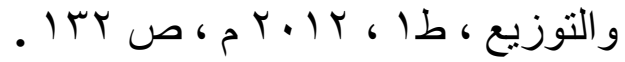

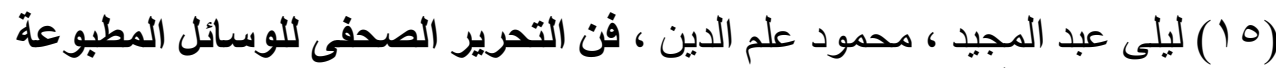

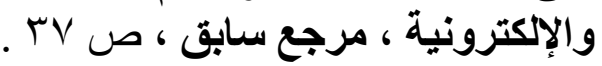




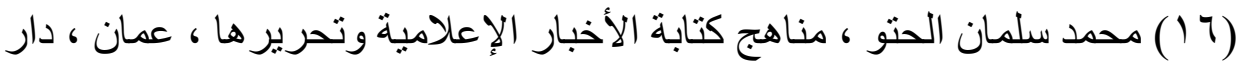

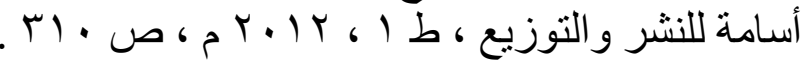

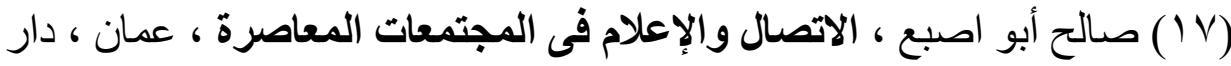

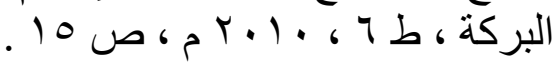

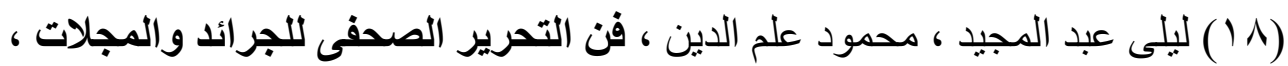

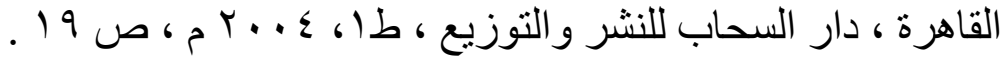

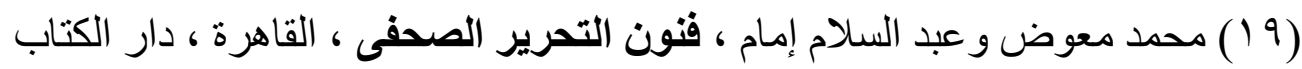

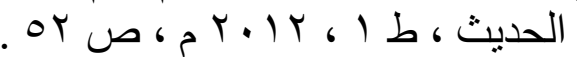

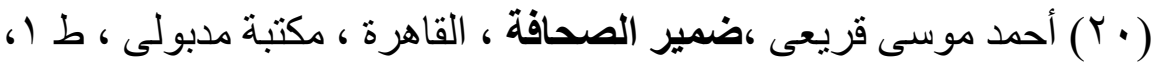
(r)

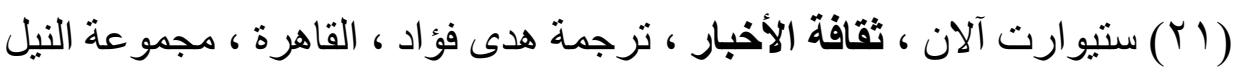

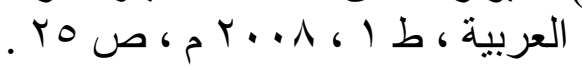

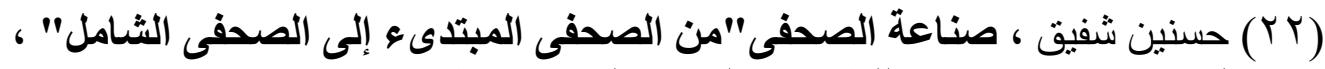

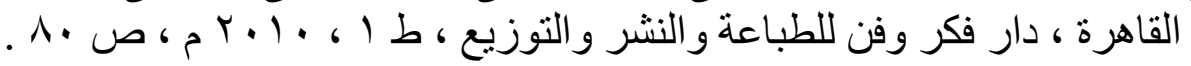

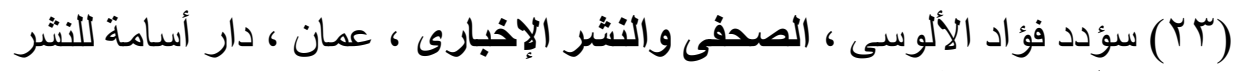

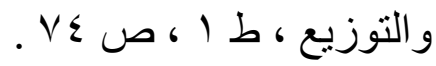

(Y (Y) عزة عبد العزيز عثمان ، مصداقية الإعلام العربى ، القاهرة ، العربى لللنشر

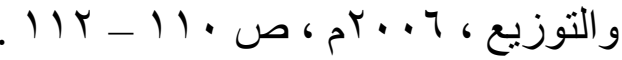

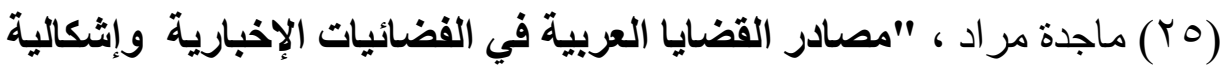

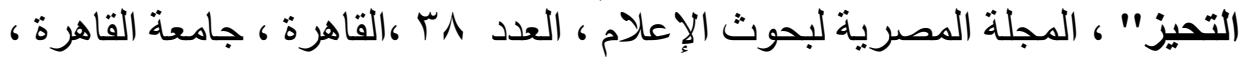

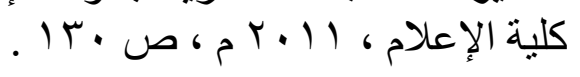

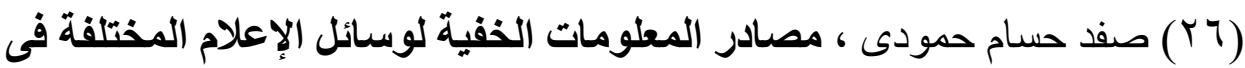

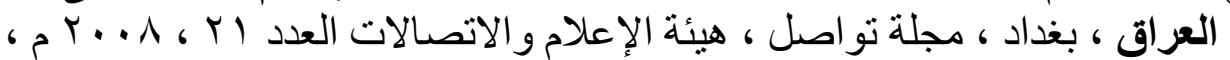

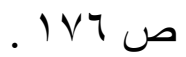

(27) De Burgh, Hugo, Investigative journalism, Tylor and Friends group, London, second edition, 2008, p179.

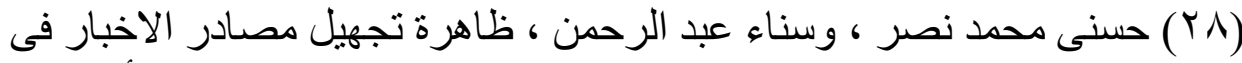

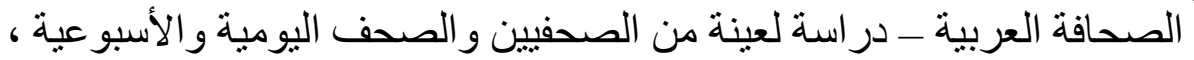

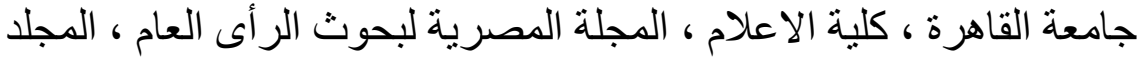

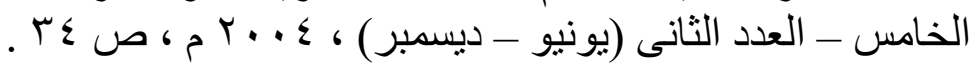

(29) Denice, Rundicki, the use of unnamed sources in the Globe and mail, Candian journal of media studies, Vol.2, 2006,No 2, p.63.

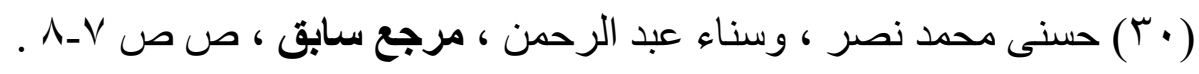

(31) Jason Beaird, The principles of Beautiful Web Design, 1 st

Ed., (Australia: Site Point pty, 2007) Pp.4-6.

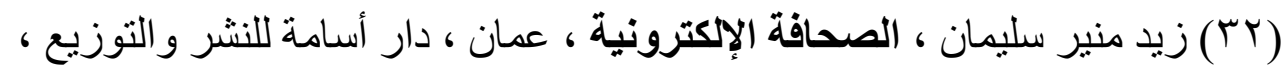

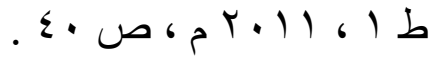


(33) Mike Ward, Journalism Online, Boston, Oxford: Focal Point, 2002, Pp.199-200.

(34) Bill Kovarik, Web Design for the Mass Media, Boston, Allyn and Bacon, 2002, p.46.

(35) Hashimoto, Alan, Visual Design Funamentals: A Digital Approach, Hingham, MA, USA: Charles River Media, 2003, p.17.

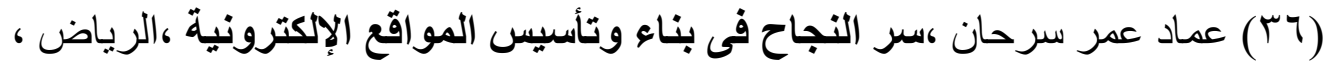

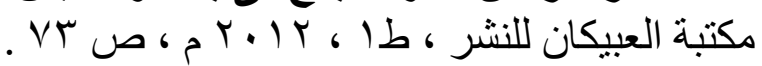

(37) Xenia Giese, Alexandra Holmes, Cisco networking academy program: fundamentals of web design Companion guide, Publisher: Indianapolis, Ind.: Cisco, London: Pearson Education, 2002.

(38) Alexander Dawson, Distinctive Design: A practical Guide to a Useful, Beautiful Web, Hobboken, NJ, USA: Wiley, 2011, p.117.

(39) Ibid.pp.117-118.

(40) Jason Beaird, The principles of Beautiful Web Design, 1 st Ed., (Australia: Site Point pty, 2007), pp.69-70 .

(41) Xenia Giese, Alexandra Holmes, OP. Cit. pp.63-72.

(42) Janine Warner, Web Sites Do-It-Yourself for Dummies, $2^{\text {nd }}$ ed, Hoboken, NJ, USA: Wiley, 2010.pp.13-18.

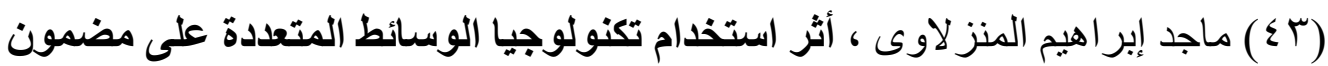

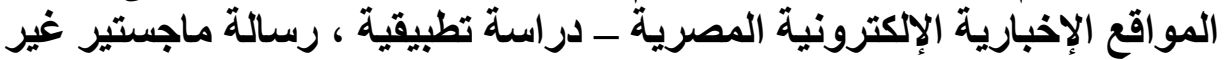

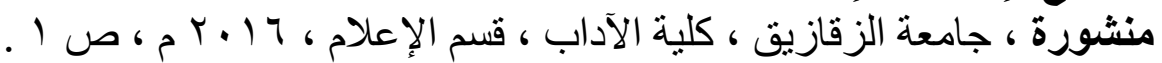

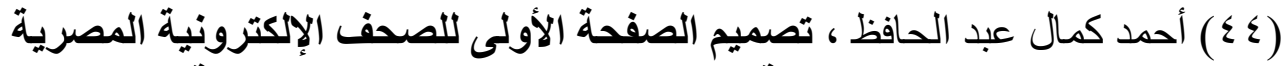

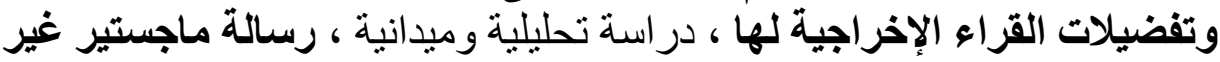

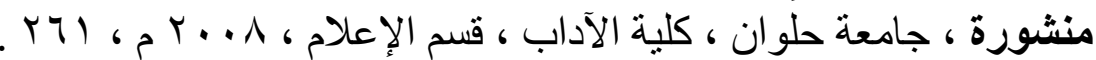

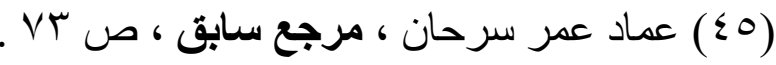

(46) Ann Navarro, Effective Web Design, sybex Inc, $2^{\text {nd }}$ edition, 2001, pp.227- 228.

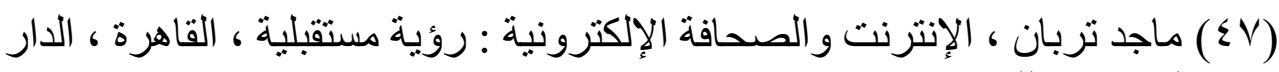

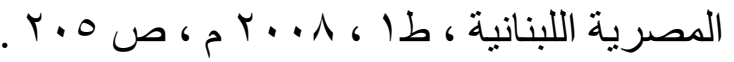

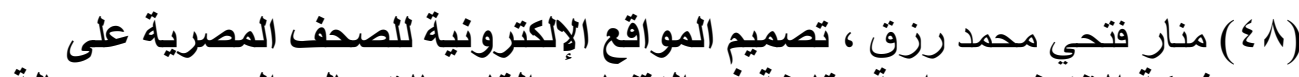

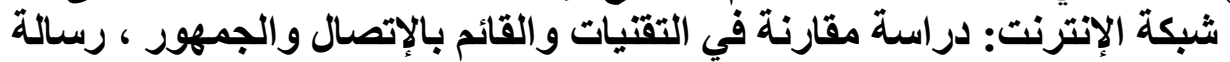

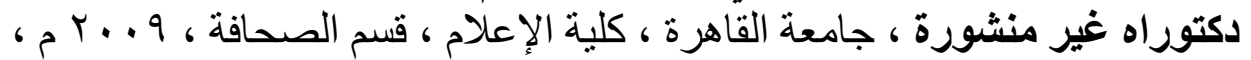




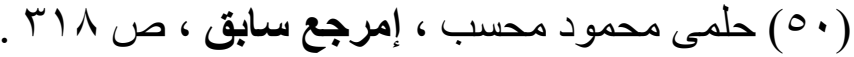

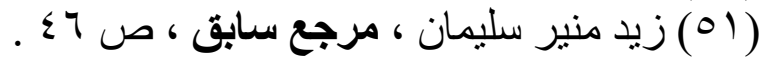

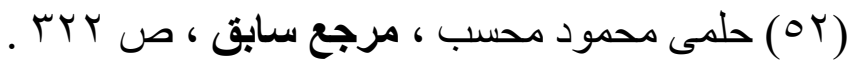

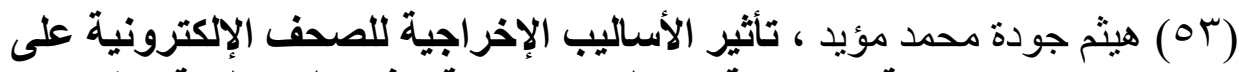

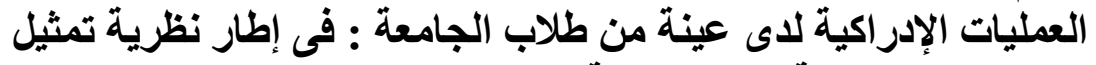

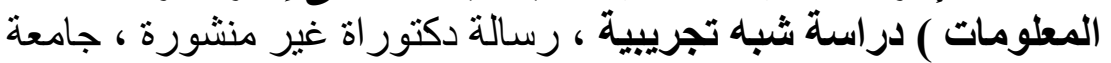

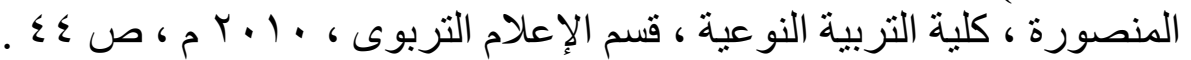

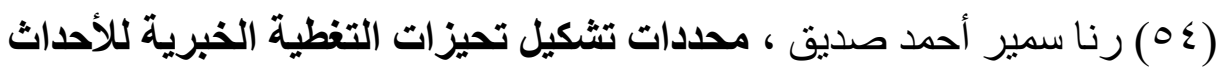

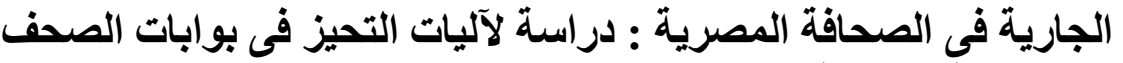

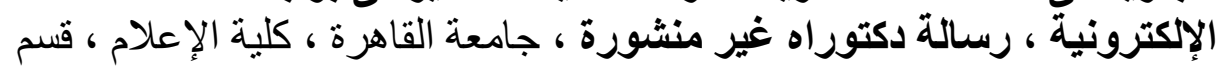

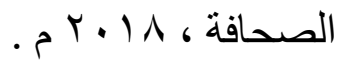

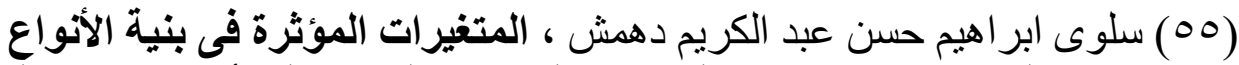

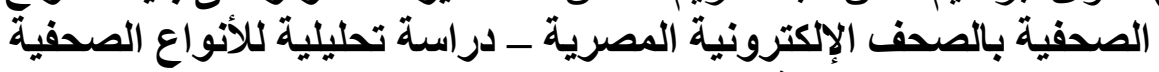

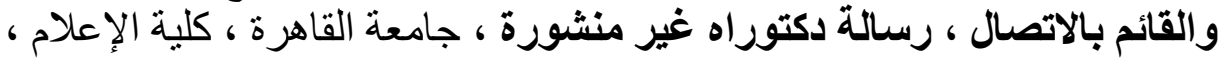

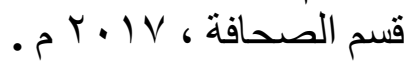

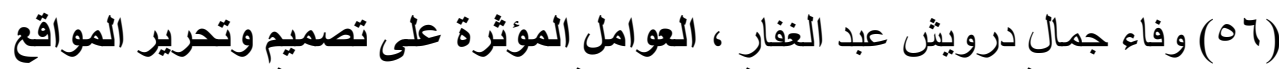

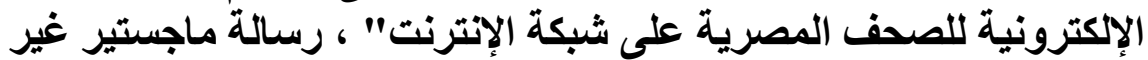

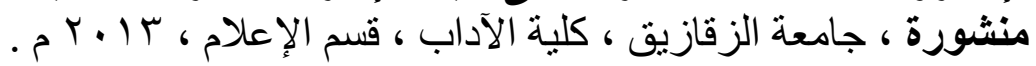

(57) Jonas Xavier Caballero, The Impact of Media Bias on Coverage of Catastrophic Events: Case Study from The New York Times' Coverage of the Palestine/ Israel Conflict', M.Sc. Thesis, Pennsylvania University of Pittsburgh, 2010.

$$
\text { (01) منار فتحي محمد رزق ، مرجع سابق . }
$$

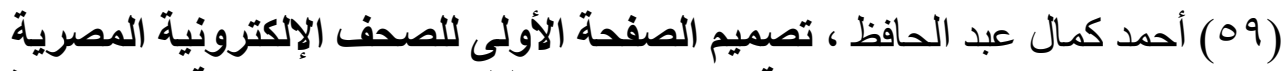

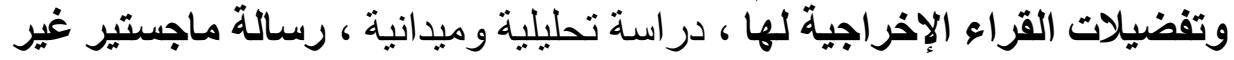

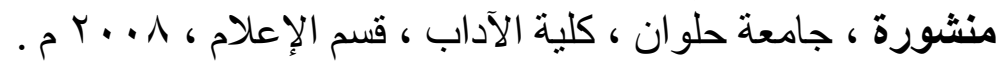

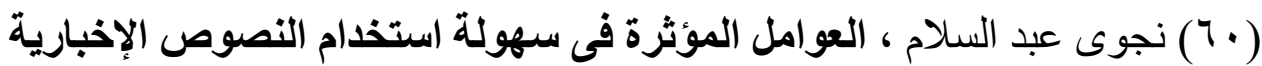

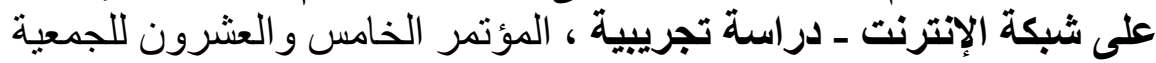

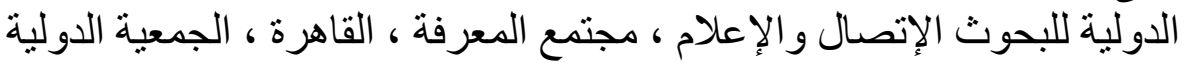

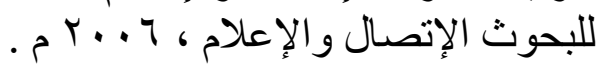

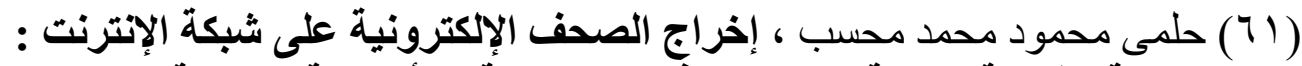

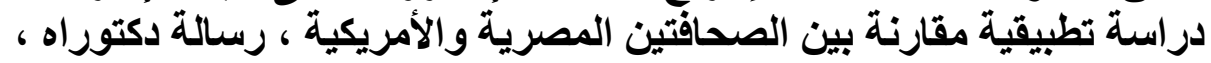

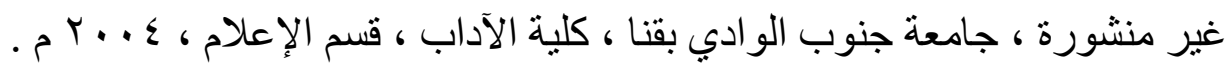

(62) Utt, S., \& Pasternack, S., "Front Page Design: Some Trends

Continue", Newspapers Research Journal, Vol.24, No.3, summer 2003. 